\title{
Revisão taxonômica das espécies de Mimosa ser. Leiocarpae sensu lato (Leguminosae - Mimosoideae)
}

Taxonomic revision of the species of Mimosa ser. Leiocarpae sensu lato (Leguminosae Mimosoideae)

\author{
Juliana Santos-Silva ${ }^{1}$, Marcelo Fragomeni Simon $^{2}$ \& Ana Maria Goulart de Azevedo Tozzi ${ }^{3}$
}

\begin{abstract}
Resumo
Mimosa ser. Leiocarpae, com 31 espécies distribuídas predominantemente em ambientes semiáridos da América do Sul, é a maior série de M. sect. Batocaulon. Muitas das suas espécies são mal definidas, o que é agravado pela ausência de ilustrações para maioria delas e a escassez de coleta de alguns táxons. Apresentamos a revisão taxonômica das espécies de $M$. ser. Leiocarpae, incluindo descrição, reavaliação nomenclatural e tipificação, delimitação dos táxons, chave de identificação e ilustrações. Foram propostas 11 novas sinonimizações, sete lectotipificação e um novo status, resultando na diminuição do número de espécies de 31 para 28. Além disso, foram complementadas as descrições originais de três espécies e registradas três novas ocorrências, sendo uma para o Brasil, uma para a Bolívia e uma para o Paraguai.
\end{abstract}

Palavras-chave: jurema, lectotipificação, Mimosa sect. Batocaulon, táxon infragenérico, taxonomia.

\begin{abstract}
Mimosa ser. Leiocarpae, with c. 31 species found primarily in semi-arid habitats in South America, is the most speciose series of $M$. sect. Batocaulon. Many of the species are poorly defined, which is aggravated by the lack of illustrations for most species and the scarcity of collection of some taxa. We present a taxonomic revision of the species of $M$. ser. Leiocarpae, including species descriptions, a re-evaluation of nomenclature and typification, delimitations of taxa, a key to the species, and illustrations. We propose eleven synonymies, seven lectotypifications, and one new status, resulting in fewer species, a change from 31 to 28 . Furthermore, we provide supplement additional material for three previous descriptions and three new geographic records, one for Brazil, one for Bolivia and one for Paraguay.
\end{abstract}

Key words: jurema, lectotypification, Mimosa sect. Batocaulon, infrageneric taxa, taxonomy.

\section{Introdução}

Mimosa L. é o segundo maior gênero da subfamília Mimosoideae e pertence à tribo Mimoseae s.l., que consiste de cerca 870 espécies agrupadas em 40 gêneros (Luckow 2005). Mimosa conta com mais da metade das espécies da tribo, aproximadamente 540 , as quais são predominantemente neotropicais (Barneby 1991; Simon et al. 2011), com poucas espécies ocorrendo em Madagascar (ca. 31 spp.), África continental (ca. 4 spp.) e Ásia (ca. 4 spp.).
Tratamentos taxonômicos abrangentes sobre Mimosa são encontrados em Bentham (1841, 1875, 1876), Burkart (1948) e, mais recentemente, em Barneby (1991), que classificou o gênero em cinco seções (M. sect. Batocaulon DC., M. sect. Calothamnos Barneby, M. sect. Habbasia DC., M. sect. Mimadenia Barneby e M. sect. Mimosa), 41 séries e 37 subséries.

Estudos filogenéticos demonstram que o gênero Mimosa, como tradicionalmente circunscrito, constitui um grupo monofilético (Luckow et al. 2000; Sulaiman et al. 2003; Jobson

\footnotetext{
${ }^{1}$ Universidade do Estado da Bahia, Depto. Ciências Humanas-DCH/Campus VI, 46400-000, Caetité, BA, Brasil. jullybandeira@hotmail.com

${ }^{2}$ Embrapa Recursos Genéticos e Biotecnologia, PqEB, 70770-901, Brasília, DF, Brasil. marcelo.simon@embrapa.br

${ }^{3}$ Universidade Estadual de Campinas, Inst. Biologia, Depto. Biologia Vegetal, 13083-862, Campinas, SP, Brasil. anatozzi@unicamp.br
} 
\& Luckow 2007; Bessega et al. 2008; Simon et al. 2011), tendo como provável grupo-irmão o clado "Eupiptadenia" [= Piptadenia s.str. definido por Jobson \& Luckow (2007)]. Com relação a sua classificação infragenérica, a maioria das seções e séries reconhecidas por por Barneby (1991) não se mostraram monofiléticas.

Apesar de parte dos problemas de delimitação e de nomenclatura das espécies de Mimosa ter sido resolvida no tratamento de Barneby (1991), ainda existe uma grande dificuldade na identificação das mesmas devido, principalmente, à utilização de caracteres crípticos e variáveis para separação das espécies e à falta de ilustrações. Por isso é comum encontramos muitos espécimes erroneamente identificados ou indeterminados nos herbários.

Como definida por Barneby (1991), Mimosa sect. Batocaulon constitui uma das seções mais polimórficas do gênero, com 25 séries e 190 espécies americanas. Dentre as suas séries, Mimosa ser. Leiocarpae Benth., caracterizada pela presença de tricomas simples, ramificados e glandulares, e flores tetrâmeras reunidas em espigas cilíndricas (Barneby 1991), destaca-se por ser a maior, com aproximadamente 28 espécies distribuídas predominantemente em ambientes semiáridos da América do Sul. Para o Brasil, foram registradas 23 espécies nesta série, distribuídas principalmente nas regiões Centro-Oeste e Nordeste (Barneby 1991). Depois da monografia de Barneby, três novas espécies da América do Sul foram descritas e incluídas em $M$. ser. Leiocarpae: $M$. craspedisetosa (Fortunato \& Palese 1999), M. ferricola (Silva \& Tozzi 2011) e M. urandiensis (Santos-Silva et al. 2013b), e consequentemente a série agora totaliza 31 espécies. Informações sobre algumas de suas espécies podem ser encontradas ainda em floras regionais, principalmente, do estado da Bahia (Lewis 1987), Caatinga (Queiroz 2009) e Pernambuco (Santos-Silva \& Sales 2008, 2010).

Muitos dos táxons de Mimosa ser. Leiocarpae apresentam grande semelhança fenotípica entre si, delimitação taxonômica imprecisa e não são devidamente ilustrados na literatura, o que justifica um estudo taxonômico conjunto dos táxons subordinados a $M$. ser. Leiocarpae. Adicionalmente, muitas de suas espécies possuem vários táxons infraespecíficos (variedades), como M. arenosa (Willd.) Poir. (três), $M$. acutistipula (Mart.) Benth. (dois), M. adenophylla Taub. (três) e M. gemmulata Barneby (cinco), corroborando a afirmação acima e gerando problemas nomenclaturais, de tipificação e de identificação.

Diante do exposto e considerando a riqueza de táxons de Mimosa ser. Leiocarpae s.l na flora brasileira, a dificuldade de identificação destes táxons e as relações taxonômicas intra e interespecíficas problemáticas, este estudo tem como objetivo revisar a taxonomia das espécies incluídas em Mimosa ser. Leiocarpae sensu Barneby (1991), abrangendo avaliação na nomenclatura, chave de identificação, descrições, ilustrações e atualizações de dados geográficos e de ambientes preferenciais.

\section{Material e Métodos}

Este estudo foi realizado a partir do levantamento bibliográfico, consulta à herbários e de coleta de material botânico em viagens de campo. Foram analisados cerca de 2000 espécimes de $M$. ser. Leiocarpae s.l. depositados em 27 herbários brasileiros e oito herbários estrangeiros (ALCB, ASE, BHCB, BM, CEN, CGMS, ESA, F, HAF, HRB, HUEFS, HUNEB, IAC, IBGE, IPA, INPA, LP, LPAG, K, MBM, MO, NY, PEUFR, OUPR, R, RB, SP, SPF, TEPB, UEC, UFG, UFP, UB, UPCB e US, acrônimos segundo Thiers continuamente atualizado) por consulta local ou cujas exsicatas foram recebidas por meio de empréstimo. Foram realizadas 23 excursões para a coleta de material botânico e observação das populações em ambiente natural. As amostras coletadas foram processadas conforme as regras usuais de herborização sugeridas por Mori et al. (1989) e posteriormente incorporadas ao acervo do Herbário UEC.

A identidade das espécies foi estabelecida através de suas diagnoses originais e comparação com a coleção-tipo ou com fotografias da mesma. As abreviações dos nomes dos autores das espécies seguiram Brummitt \& Powell (1992). Para alguns táxons, foi necessário um "segundo passo" de lectotipificação, como recomendado pelo art. 9.15 do ICBN (McNeil et al. 2012), para esclarecer e estabelecer as escolhas de lectótipo realizadas por Barneby (1991).

As descrições foram baseadas nos espécimes examinados e estão padronizadas de acordo com a terminologia de Radford et al. (1974) adicionalmente à de Barneby (1991) para os termos de parafilídios e espículas. A análise morfológica foi realizada no Laboratório de Taxonomia Vegetal do Departamento de Biologia Vegetal, IB/ UNICAMP, com o auxílio de estereomicroscópio 
(Zeiss). As medidas do pecíolo foram tomadas incluindo o pulvino; as medidas da ráquila foram baseadas nos folíolos mais longos; para os foliólulos foram incluídos tanto os maiores quanto os menores. As dimensões das inflorescências foram obtidas excluindo os filetes e as do cálice incluindo as lacínias.

As informações sobre distribuição geográfica, ambiente preferencial, períodos de floração e frutificação das espécies foram obtidas nas etiquetas das exsicatas e referenciadas quando complementadas com informações da literatura. No apêndice 1 encontra-se a lista de coletores, organizada em ordem alfabética.

\section{Resultados e Discussão}

\section{Caracterização morfológica do gênero Mimosa L.}

Mimosa L., Sp. P1. 516.1753. Espécie-tipo: Mimosa sensitiva L.

Árvores, arbustos, subarbustos, ervas ou lianas; ramos cilíndricos ou costados, inermes ou aculeados; acúleos retos ou curvados, distribuídos de três diferentes maneiras: infranodais $(2-3$ acúleos abaixo e próximos ao nó), internodais (acúleos dispersos no entrenó) ou formando filas longitudinais ao longo dos ramos; indumento variado, com tricomas simples, ramificados, glandulares ou setosos. Folhas bipinadas, às vezes produzindo movimentos durante a noite (nictinásticos) ou quando tocadas (tigmonásticos), raramente ausentes ou reduzidas a filódios; nectário extrafloral comumente ausente, quando presente (M. sect. Mimadenia) séssil, discóide, localizado no pecíolo ou entre o primeiro par de folíolos; folíolos opostos; espículas ausentes ou presentes na raque ou entre os pares de folíolos; os primeiros foliólulos de cada pina às vezes diferenciados, reduzidos (parafilídios). Inflorescências espigas, cilíndricas, elipsoides, globosas ou raramente subglobosas, axilares, solitárias ou agrupadas em pseudorracemos ou panículas axilares ou terminais. Flores sésseis, raramente curto-pediceladas, 3-5(6) meras, bissexuadas, raramente unissexuadas (funcionalmente estaminadas, com gineceu rudimentar ou ausente); cálice reduzido, muitas vezes obsoleto, campanulado, lacínias curtas e pouco conspícuas até longas e paleáceas; corola cilíndrica, quadrangular ou campanulada, creme, rosada ou vinácea no ápice das lacínias; estames em número igual ou o dobro das lacínias da corola, exsertos, com filetes livres ou brevemente unidos na base, brancos, rosados ou lilás, anteras dorsifixas, oblongas ou globosas, não glandulares, grãos de pólen unidos em tétrades, bitétrades ou políades com 12 a 16 grãos; ovário séssil ou curtamente estipitado, estilete filiforme, glabro a indumentado, estigma apical, punctiforme, raramente capitado. Frutos craspédios articulados ou craspédios não articulados, sésseis ou estipitados, compressos ou ondulados, membranáceos ou coriáceos, armados ou inermes, lineares, elípticos ou oblongos. Sementes plano-compressas, ovais ou orbiculares, marrom-claras, marrom-escuras a pretas.

\section{Histórico de Mimosa ser.} Leiocarpae Benth.

A série Leiocarpae foi proposta por Bentham (1841) para agrupar três espécies americanas caracterizadas, principalmente, pela presença de espigas longas, cilíndricas e flores tetrâmeras. Neste tratamento, outras espécies que hoje compõem Mimosa ser. Leiocarpae sensu Barneby foram descritas e posicionadas em M. sect. Habbasia e nas séries M. ser. Tomentosae Benth. (M. discolor, M. pteridifolia Benth., M. schomburgkii Benth. e $M$. verrucosa Benth.) e $M$. ser. Caesalpiniaefoliae Benth. (M. sericantha Benth.). Bentham (1846) manteve a classificação anterior, mas alterou a circunscrição de praticamente todas as seções e séries. Em M. ser. Leiocarpae foram incluídas oito espécies, e desse modo a série passou a contar com 11 espécies.

Bentham (1875) propôs uma nova série para a Mimosa sect. Habbasia denominada M. ser. Leptostachyae, cuja circunscrição incluía todas as espécies das séries Leiocarpae, Tomentosae e Caesalpiniaefoliae. Mimosa ser. Leptostachyae sensu Bentham (1875) reunia 30 espécies com características florais que nitidamente formavam dois grupos. O primeiro incluía espécies com flores pentâmeras e 10 estames, todas basicamente ocorrendo no México e na Colômbia, e o segundo formado por espécies brasileiras com flores tetrâmeras e oito estames, raramente 4-5-meras.

Barneby (1991) não utilizou o nome Leptostachyae proposto por Bentham (1875) pois ele incluiu os tipos de três séries que teriam prioridade nomenclatural (M. ser. Leiocarpae, $M$. ser. Tomentosae e M. ser. Caesalpiniaefoliae), considerando-o ilegítimo. Além disso, subordinou a maioria das espécies incluídas por Bentham (1875) em M. ser. Leptostachyae em duas séries: M. ser. Leiocarpae e M. ser. Distachyae Barneby. 
Em M. ser. Distachyae foram incluídas as espécies com flores em sua maioria 5-meras e folhas com 1-30 pares de folíolos. Esta série é predominantemente mexicana, com exceção de $M$. distachya Cav. que ocorre no Caribe estendendo-se até Colômbia e Venezuela. Mimosa ser. Leiocarpae reuniu a maioria das espécies sulamericanas com flores tetrâmeras. Outras espécies de $M$. ser. Leptostachyae foram sinonimizadas ou transferidas para as demais seções e séries de Mimosa, como M. platycarpa Benth (= M. acantholoba (Humb. \& Bonpl. ex Willd.) Poir., M. caduca (M. ser. Bimucronatae Barneby), $M$. caesalpiinifolia Benth. (M. ser. Caesalpiniifoliae Benth.) e $M$. pithecolobioides Benth. e $M$. lasiophylla Benth. (= M. pithecolobioides, $M$. sect. Mimadenia) ou ainda, para outro gênero de Mimosoideae (M. warmingii Benth.= Pseudopiptadenia warmingii (Benth.) G.P. Lewis \& M.P. Lima).

Mimosa ser. Leiocarpae ainda foi subdividida por Barneby (1991) em cinco grupos informais, a saber: 1) folíolos sem glândulas e fruto planocompresso (M. arenosa (Willd.) Poir., $M$. hapaloclada Malme, M. acutistipula Benth., M. dichroa Barneby, M. ophthalmocentra Mart. ex Benth., M. mensicola Barneby); 2) folíolos sem glândulas e fruto tetragonal com replo mais ou menos da mesma largura das valvas ( $M$. dalyi Barneby, M. insignis (Hassl.) Barneby); 3) folíolos com glândulas, cálice 4-angulado e frutos com valvas buladas (M. tenuiflora (Willd.) Poir.); 4) folíolos com glândulas, cálice campanulado e frutos com valvas não buladas ( $M$. apodocarpa Benth., M. interrupta Benth., M. glutinosa Malme, M. hebecarpa Benth., M. spixiana Barneby, $M$. sericantha Benth., M. puberula Benth., $M$. pteridifolia Benth., M. adenophylla Taub., $M$. gemmulata Barneby, M. amnis-atri Barneby, M. nothopteris Barneby, M. fiebrigii Hassl., M. coruscocaseia Barneby); 5) cálice e fruto revestidos por tricomas estrelados ou verrucosos (M. verrucosa Benth., M. schomburgkii Benth., M. trianae Benth.).

Grether (2000), observando a sobreposição dos caracteres diagnósticos usados por Barneby (1991), sinonimizou Mimosa ser. Distachyae à $M$. ser. Leiocarpae. No entanto, as análises filogenéticas baseadas em dados moleculares não sustentaram a hipótese de Grether (2000), uma vez que as espécies desses grupos formaram clados distintos (Santos-Silva et. al. 2013; Simon et al. 2011).

Após a publicação da monografia de Barneby (1991), três novas espécies da América do Sul foram descritas e incluídas em Mimosa ser. Leiocarpae: M. craspedisetosa (Fortunato \& Palese 1999), M. ferricola (Silva \& Tozzi 2011) e M. urandiensis (Santos-Silva et al. 2013b). Atualmente a série abrange 31 espécies.

\section{Chave para a identificação das espécies de Mimosa ser. Leiocarpae sensu lato}

1. Foliólulos sem pontuações glandulares ou glândulas sésseis na face abaxial.

2. Ráquila serreada.

3. Ramos com indumento constituído por tricomas simples e lepidotos; folhas com (16-) 17-21 pares de folíolos e (20-) 30-47 pares de foliólulos; espículas ausentes; ráquila 3,5-4,5 cm compr.; filetes róseos 8. Mimosa dalyi

3'. Ramos glabros; folhas com (4-) 7-10 pares de folíolos e 68-100 pares de foliólulos; espículas presentes; ráquila $8-10,5 \mathrm{~cm}$ compr.; filetes brancos 15. Mimosa insignis

2'. Ráquila cilíndrica, subcilíndrica, caniculada ou sulcada.

4. Indumento constituído por tricomas capitado-glandulares; estípulas ciliada-glandulares; bractéolas ciliada-glandulares; ovário seríceo .... 26. Mimosa urandiensis

4'. Indumento sem tricomas capitado-glandulares; estípulas e bractéolas não ciliada-glandulares; ovário glabro, piloso, puberulento, pubescente, viloso a lanuginoso.

5. Filetes brancos.

6. Frutos sésseis.

7. Acúleos presentes na raque foliar, no eixo principal da inflorescências e na ráquila; folhas com 4-7 pares de foliólulos; lâmina 12-20 × 4-10 mm, 4-7-nervada; corola campanulada ou cilíndrica... 17. Mimosa mensicola

7'. Acúleos restritos aos ramos; folhas com 11-24 pares de foliólulos; lâmina 4,5-9 × 1-1,5 mm, 3-nervada; corola tubulosa, 4-angulada 
6'. Frutos estipitados.

8. Foliólulos membranáceos; frutos marrons.

4. Mimosa arenosa

8' Foliólulos cartáceos; frutos castanhos a vináceos 1. Mimosa acutistipula

5'. Filetes róseos.

9. Ramos inermes; folhas com 6-9 pares de folíolos e 22-30 pares de foliólulos; ráquila 6,5-10 cm compr.; lâmina 7-13 × 2-4 mm, cartácea; 2-nervada; ovário séssil .

9. Mimosa dichroa

9'. Ramos aculeados; folhas com 13-25 pares de folíolos e 31-36 pares de foliólulos; ráquila 1,8-3 cm compr.; lâmina 2-4 × 0,5-0,6 mm, membranácea, 1-nervada; ovário estipitado ...

13. M. hapaloclada

1'. Foliólulos com pontuações glandulares ou glândulas sésseis na face abaxial.

10. Indumento constituído por tricomas estrelados, estrelado-lepidotos, medusiformes, verruciformes entremeados com tricomas glandulares.

11. Arbustos com até $4 \mathrm{~m}$ de altura; base dos foliólulos oblíqua ou arredondada; filetes róseos.

12. Ramos revestidos por tricomas medusiformes; face adaxial dos foliólulos glauca; corola puberulenta; frutos subtúrgidos, puberulentos, vilosos a tomentosos

6. Mimosa coruscocaesia

12'. Ramos revestidos por tricomas verruciformes; face adaxial dos foliólulos verde-escuro; corola lanosa; frutos compressos, revestidos por tricomas verruciformes

27. Mimosa verrucosa

11'. Árvores com 5-25 m de alt.; base dos foliólulos truncada ou auriculada; filetes brancos.

13. Foliólulos cartáceo-coriáceos, discolores, com a margem revoluta e face adaxial verdeescuro, puberulenta a pilosa e abaxial esbranquiçada, lanosa..........25. Mimosa trianae

13'. Foliólulos cartáceos, concolores, com margem não revoluta e face adaxial glabra a pilosa e abaxial com esparsos tricomas verruciformes ao longo das nervuras, verde

\section{Mimosa schomburgkii}

10’. Indumento constituído por tricomas simples entremeados por glandulares.

14. Foliólulos $15-45 \mathrm{~mm}$ compr.

22. Mimosa sericantha

14'. Foliólulos 1-10 mm compr.

15. Inflorescências latentes simultaneamente com as espigas expandidas ou até mesmo com infrutescências; cálice 4-angulado; artículos inflados na região das sementes

24. Mimosa tenuiflora

15'. Inflorescências latentes ausentes; cálice cupuliforme ou tubuloso; artículos compressos ou elevados na região da semente.

16. Filetes brancos.

17. Cálice e corola não resinosos; frutos cartáceos

3. Mimosa apodocarpa

17’. Cálice e corola resinosos; frutos sublenhosos.

18. Ramos castanhos; foliólulos 6-10 × 1,2-3 mm, subcoriáceos, com a face adaxial lustrosa, 2-4-nervados; artículos compressos

16. Mimosa interrupta

18'. Ramos acizentados, quando jovens; foliólulos 3-4,7 × 0,7-1 mm, cartáceos, com a face adaxial opaca, 1-nervado; artículos elevados na região da semente

12. Mimosa glutinosa

16'. Filetes róseos.

19. Espigas com $1-1,5 \mathrm{~cm}$ compr.

10. Mimosa fiebrigii

19'. Espigas com 3-18 cm compr.

20. Folíolos de tamanhos iguais na mesma folha........2. Mimosa amnis-atri

20'. Folíolos com diferentes tamanhos na mesma folha.

21. Foliólulos com base truncada e margem frequentemente revoluta. 20. Mimosa pteridifolia

21'. Foliólulos com base oblíqua, arredondada a discretamente cordada e margem não revoluta. 
22. Ramos aculeados.

23. Foliólulos 3-5 × 1-1,4 mm; espigas 6-9 cm compr.; cálice $0,4-0,8 \mathrm{~mm}$ compr.; ovário glandularpapilado

18. Mimosa nothopteris

23'. Foliólulos 2-2,5 × 0,5-0,7 mm; espigas 3-6 cm compr.; cálice 0,3-0,4 mm compr.; ovário viloso com glândulas esparsas 7. Mimosa craspedisetosa

22'. Ramos inermes.

24. Foliólulos 1,2-2 mm compr. 11. Mimosa gemmulata

24'. Foliólulos 3-10 mm compr.

25. Folhas com 4-9 pares de folíolos e 9-20 (28) pares de foliólulos; lâmina com a face adaxial sublustrosa, 2-5-nervada; cálice e corola tomentosos a seríceos; frutos estipitados

23. Mimosa spixiana

25'. Folhas com 10-37 pares de folíolos e 28-54 pares de foliólulos; lâmina com face adaxial opaca, 1-nervada; cálice glabro, puberulento ou tomentoso; corola glabra, tomentosa a vilosa; frutos sésseis.

26. Folhas com 10-21 pares de folíolos; ráquila 4,5-8 cm compr.; espigas desenvolvendo em ramos velhos desfolhados abaixo das folhas; corola tomentosa a vilosa; frutos tomentosovilosos 14. Mimosa hebecarpa

26'. Folhas com 26-37 pares de folíolos; ráquila 3,5-4,2 cm compr.; espigas desenvolvendo em ramos contemporâneos; corola glabra; frutos glabros....... 5. Mimosa caccavariana

\section{Descrição das espécies de Mimosa ser. Leiocarpae sensu lato}

1. Mimosa acutistipula (Mart.) Benth., J. Bot. (Hooker) 4: 391-392. 1841. Tipo: sob Mimosa acutistipula (Mart.) Benth. var. acutistipula.

Fig. 1

Arbusto a arvoreta $2-8 \mathrm{~m}$ alt.. Ramos inermes ou aculeados, puberulentos, castanhos a acinzentados. Acúleos internodais, retos a discretamente curvos, com base larga, às vezes, presente na raque foliar. Tricomas simples esbranquiçados, às vezes, entremeados por esparsos tricomas glandulares estipitados distribuídos nos ramos, frutos e raramente no cálice. Estípulas 3-7 $\times 0,2-1 \mathrm{~mm}$, triangulares a subuladas, não ciliada-glandulares, 1-nervada. Folhas $3-10$ pares de folíolos crescentes; pecíolo 0,6-1,5 cm compr.; raque 1,5-10 cm compr., interrompida ou não entre cada par de folíolos por espícula; segmento da raque $0,6-1,5 \mathrm{~cm}$ compr.; foliólulos 19-38 pares, decrescentes proximalmente; ráquila $2-8,5 \mathrm{~cm}$ compr., canaliculada; lâmina 3-13 × 0,7-3 mm, cartácea, oblonga, base oblíqua a discretamente truncada, ápice agudo a acuminado, margem não revoluta, ciliada, glabra a pubescente, face abaxial sem pontuações glandulares ou glândulas sésseis, 1-3-nervada. Pedúnculo 0,5-1 cm compr..; brácteas ausentes. Espigas 1,5-7,5 x 0,4-0,5 cm, congestas, solitárias a 3-fasciculadas, reunidas em panículas terminais nos ramos desfolhados ou nas axilas de folhas totalmente desenvolvidas; inflorescências latentes ausentes; bractéolas persistentes, menores que o botão floral, $5-8 \times 0,2-0,3 \mathrm{~mm}$, lanceoladas, oblanceoladas a subuladas, não ciliada-glandulares. Flores tetrâmeras, bissexuadas, sésseis; cálice 0,5-0,7 mm compr., cupuliforme, ciliado, glabro a pubescente; corola $1,5-2,3 \mathrm{~mm}$ compr., campanulada, glabra a pubescente no ápice, lacínias eretas; filetes 5-7 $\mathrm{mm}$ compr., livres, brancos; ovário $0,8-1 \mathrm{~mm}$ compr., estipitado, estípite ca. $0,2 \mathrm{~mm}$, glabro; estilete $7-8 \mathrm{~mm}$ compr.. Craspédios 4,5-9,5 × 0,6-1 cm, cartáceocoriáceos, 7-9-articulados, estipitados, estípite 6-8 mm, oblongos a lineares, base atenuada, ápice mucronulado, glabros a glabrescentes, castanhos a vináceos; artículos quadrangulares a retangulares, lustrosos, compressos; réplum reto, 0,6-0,7 $\mathrm{mm}$. Sementes 3-4 × 2-2,5 mm, ovoides, castanhas.

Mimosa acutistipula é caracterizada pelos ramos aculeados, algumas vezes inermes, pela raque foliar com 1,5 a $6 \mathrm{~cm}$ de comprimento, sendo um dos menores tamanhos observado entre as espécies. Os frutos são frequentemente vináceos, lustrosos, longamente estipitado (6-8 mm), com nervuras reticuladas evidentes em ambas as faces.

Nos herbários é comum encontrarmos espécimes de $M$. acutistipula erroneamente indentificados como M. ophthalmocentra. A distinção entre essas espécies, que compartilham o hábito arbustivo, os ramos aculeados, espigas relativamente curtas e filetes brancos, pode ser feita com base principalmente no número de nervuras 
das estípulas, apenas uma em $M$. acutistipula e três em $M$. ophthalmocentra, no formato da corola, campanulada na primeira e 4-angulada na segunda e na morfologia do fruto, longo estipitado em $M$. acutistipula e séssil em em $M$. ophthalmocentra.

Barneby (1991) reconheceu duas variedades: Mimosa acutistipula var. acutistipula e M. acutistipula var. ferrea, diferenciadas pelo número de folíolos e pelo tamanho das inflorescências, associada a distribuição de suas populações. As análises dos indivíduos em campo e dos espécimes examinados, demonstraram que, realmente, existe uma variação no número de pares de folíolos e no tamanho da inflorescência, sendo esta variação descontínua, portanto, mantemos estas duas variedades .

Do latim, acutistipula (acutus = pontiagudo, afilado; stipula $=$ estípula) refere-se ao aspecto filiforme das estípulas.

\section{Chave para Identificação das variedades de Mimosa acutistipula}

1. Folhas maiores com 3-7 pares de folíolos e 19-23 pares de foliólulos; espigas 1,5-5 cm compr......... 1.1. var. acutistipula

1'. Folhas maiores com 7-11 pares de folíolos e 24-38 pares de foliólulos; espigas 5-8 cm compr. 1.2. var. ferrea

1.1 Mimosa acutistipula (Mart.) Benth. var. acutistipula, J. Bot. (Hooker) 4: 391-392. 1841. Acacia acutistipula Mart., Herbarium florae brasiliensis 2: 107. 1837. Tipo: In pratis udis Varedas dictis in prov. Piauhiensis, Martius s.n. (Lectótipo: M-0171177, primeiro passo lectótipo designado por Barneby 1991:128 = F Neg 6174 = IPA 1339!, segundo passo lectótipo designado aqui).

Distribuição geográfica e habitat: Mimosa acutistipula var. acutistipula foi citada por Barneby (1991) apenas para o Brasil, mas encontramos uma coleção desta variedade depositada no herbário SI, oriunda da Bolívia, Santa Cruz, tratando-se portanto, de uma nova ocorrência. Neste país é encontrada a $336 \mathrm{~m}$ de altitude, crescendo na borda de floresta úmida, em solo pedregoso, vermelho. No Brasil ocorre nos estados da Bahia, Ceará, Goiás, Mato Grosso do Sul, Pernambuco e Piauí, sendo cultivada ainda no Distrito Federal e provavelmente no Rio de Janeiro (A. Glaziou 9773). Esta variedade geralmente forma populações dominantes em vegetação de caatinga e cerrado ou em áreas degradadas destes biomas, sobre solo arenoso ou argiloso, em altitudes que variam de 180 a 850 $\mathrm{m}$. Existem, ainda, registros pontuais em áreas de transição cerrado-floresta.

Fenologia: Floresce e frutifica de janeiro a agosto. Frutos foram também observados em outubro.

Nome popular: jurema, jurema-de-cabloco, jurema-de-espinho, jurema-preta, jurema-vermelha.

O basiônimo de M. acutistipula, Acacia acutistipula, foi descrito por Martius (1837) com base em três síntipos (Martius s.n., Blanchet 2870, Garden 2135), todos oriundos do Brasil. Barneby (1991) designou a coleta de Martius s.n. depositada em M como holótipo. Interpretamos que a lectotipificação foi inferencialmente realizada por ele (primeiro passo) e estamos aqui designando a mesma coleção citada por Baneby (1991) como lectótipo (segundo passo).

Material selecionado: BOLÍVIA. SANTA CRUZ: Chiquitos, $28 \mathrm{~km}$ S e San José de Chiquitos, 5.IV.2006, fl. e fr., M.S. Ferrucci et al. 2580 (CTES, SI). BRASIL. BAHIA: Barreiras, ca. de $4 \mathrm{Km} \mathrm{N}$. de Barreiras, estrada para Santa Rita de Cássia, 5.III.1971, fl., H.S. Irwin et al. 31582 (NY, US). DISTRITO FEDERAL: Brasília, Estação Experimental de Biologia da UNB, 10.III.1972, fl., R.M. Harley 12066 (UB, US). GOIÁS: Posse, 6 Km de Alvorada do Norte, 10.X.1990, fr., S.S. Silva et al. (IBGE 2810590, US 3186172). MATO GROSSO DO SUL: Aquidauana, Rod. BR-419, 12.V.2002, fr., G. Hatschbach et al. 72860 (MBM, SPF). PERNAMBUCO: Floresta, Inajá, Reserva Biológica de Sera Negra, 20.VII.1995, fl., A.P.S. Gomes et al. 50 (K, PEUFR). PIAUÍ: Campo Maior, Fazenda Lourdes, 14.IV.2002, fl., R.R. Farias \& M.R.A. Mendes 493 (TEPB, HUEFS). RIO DE JANEIRO: s. loc., XII.1878, fl., M. A. Glaziou 973 (K).

1.2 Mimosa acutistipula var. ferrea Barneby, Mem. New York Bot. Gard. 65: 129. 1991. Tipo: Mato Grosso, Vegetação de Canga, frequente, Serra Norte, 21.VIII.1973, fr., J.M. Pires \& B.C. Passos 13207 (Holótipo: NY!).

Distribuição geográfica e habitat: Esta variedade distribui-se no estado do Maranhão, Mato Grosso e do Pará, geralmente associada a 


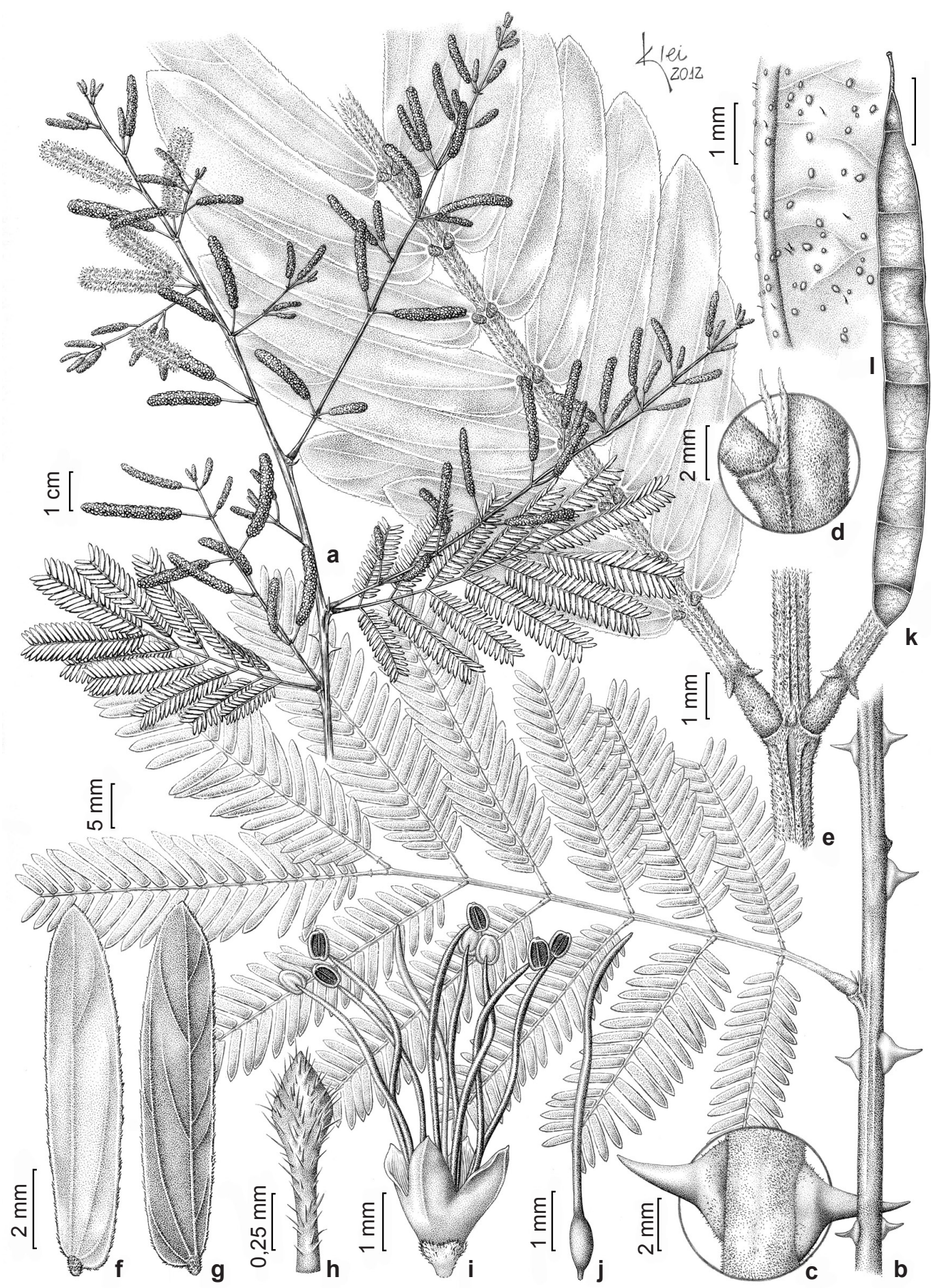

Figura 1 - Mimosa acutistipula var. acutistipula - a. ramo florido; b. folha; c. detalhes dos acúleos; d. detalhe das estípulas; e. detalhe da raque foliar mostrando a espícula e os parafilídios; f. foliólulo, face adaxial; g. foliólulo, face abaxial; h. bractéola; i. flor. j. gineceu; k. fruto; 1. detalhe do artículo mostrando as glândulas. (a-j. L.B. Bianchetti \& J.N. Silveira 736; k-1. L. Coradin et al. 5746).

Figure 1 - Mimosa acutistipula var. acutistipula - a. flowering branch; b. leaf; c. detail of aculei; d. detail of stipules; e. detail of leaf rachis, showing spicule and paraphyllidia; f. leaflet, adaxial surface; g. leaflet, abaxial surface; h. bract; i. flower; j. gynoecium; k. fruit; 1. detail of article, showing glands. (a-j. L.B. Bianchetti \& J.N. Silveira 736; k-1. L. Coradin et al. 5746). 
vegetação de canga, onde cresce em altitudes que variam de 300 a $700 \mathrm{~m}$. Alguns indivíduos também foram coletados em floresta estacional decidual no estado do Maranhão.

Fenologia: Floresce em dezembro, janeiro e abril. Frutifica em abril, maio e junho.

Nome popular: jureminha

Mimosa acutistipula var. ferrea apresenta um conjunto de características distintas da variedade típica, como, por exemplo, folhas maiores $(5,6-10$ $\mathrm{cm}$ vs. 2,5-7,5 cm), número maior de pares de folíolos (7-11 vs. 3-7) e foliólulos (24-38 vs. 19-23) e inflorescências com comprimento maior (5-8 $\mathrm{cm}$ vs. 1,5-5 cm). Além disso, estes dois táxons apresentam distribuições distintas, a var. ferrea é restrita ao estado do Maranhão e Pará, enquanto a var. acutistipula ocorre amplamente na região Nordeste podendo, ainda, ser encontrada na Bolívia (Santa Cruz).

$\mathrm{O}$ epíteto ferrea (= feito de ferro) faz referência as solos ricos em minério de ferro, típicos de vegetação de canga, onde foi coletada a coleção-tipo.

Material selecionado: BRASIL. MARANHÃO: Lorêto, Ilha de Balsas, 8.IV.1962, fl., G. Eiten \& L.T. Eiten 4184 (K, NY). PARÁ: Marabá, Serra dos Carajás, 29.I.1985, fl., O.C. Nascimento \& R.P. Bahia 1048 (MG, NY).

2. Mimosa amnis-atri Barneby, Mem. New York Bot. Gard. 65: 151-152. 1991, emend. J. SantosSilva \& A.M.G. Azevedo. Tipo: Brasil, Goiás ${ }^{1}$ : Serra do Rio Preto, $\pm 5 \mathrm{Km}$ de E. of Goiás boundary road to Guarapauá in Minas Gerais, 16 Nov 1965, H.S. Irwin et al. 10277 (Holótipo: UB!, Isótipos: G, K!, LE, NY!, P, R!, S, US!).

Fig. 2a-j

Arbustos 1,5-2,5 m alt.. Ramos inermes, tomentosos a vilosos nos ramos jovens, castanhos. Tricomas simples amarelados, entremeados por glândulas sésseis, lentiformes, amarelotranslúcidas, distribuídos nos ramos, estípulas, pecíolo, raque foliar, face abaxial dos foliólulos, eixo das espigas, bractéola, cálice, corola, ovário e craspédio. Estípulas $1-2 \times 0,2-0,3 \mathrm{~mm}$, lanceoladas a subuladas, não ciliada-glandulares. Folhas 28-49 pares de folíolos de mesmo tamanho; pecíolo 0,3-0,5 $\mathrm{cm}$; raque $5-11 \mathrm{~cm}$ de compr., interrompida entre cada par de folíolos por espícula; segmento da raque $0,2-0,3 \mathrm{~cm}$ compr.; foliólulos $14-26$ pares, crescentes; ráquila $0,8-2 \mathrm{~cm}$ compr., cilíndrica; lâmina $1-1,5 \times 0,4-0,7 \mathrm{~mm}$, cartácea-coriácea,

1 Segundo Barneby (1991), a localidade de coleta indicada tanto no caderno de campo dos coletores quanto na etiqueta como Guarapauá corresponde a Garapuava, distrito de Unaí (MG). oblonga a elíptica, base oblíqua a arredondada, ápice arredondado, margem não revoluta, ciliada, face adaxial glabra, face abaxial glabra a pilosa, 1-2-nervada. Pedúnculo 1-2 cm compr.; brácteas ausentes. Espigas (5-)11-13,5 × 0,2-0,4 cm, congestas a laxifloras, solitárias a 2 -fasciculadas, nas axilas de folhas jovens ou reunidas em ramos desfolhados terminais; inflorescências latentes ausentes; bractéolas persistentes, menores que o botão floral, 5-6 $\times 4-5 \mathrm{~mm}$, ovais a obtruladas, não ciliada-glandulares. Flores tetrâmeras, bissexuadas, sésseis; cálice $0,5-0,6 \mathrm{~mm}$ compr., cupuliforme, piloso; corola 1,5-2 $\mathrm{mm}$ compr., campanulada, pilosa, lacínias eretas; filetes 5-6 mm compr., livres, róseos; ovário $0,8-1 \mathrm{~mm}$ compr., séssil, viloso a piloso; estilete 7-8 $\mathrm{mm}$ compr.. Craspédios 4-5,5 $\times 1-1,4 \mathrm{~cm}$, cartáceos, 3-5-articulados, sésseis, lineares, base atenuada, ápice apiculado, tomentosos, castanhos; artículos elipsoides, compressos; réplum constricto entre os artículos, $0,6-0,7 \mathrm{~mm}$. Sementes 3-4 × 3-4 mm, ovais, marrons.

Distribuição geográfica e habitat: Mimosa amnis-atri é encontrada no sul de Goiás e em Minas Gerais, em áreas de cerrado e campo de cerrado ao longo de cursos d'água ou em beira de estrada, em altitudes que variam de 815 a $1000 \mathrm{~m}$.

Fenologia: Floresce de maio a julho e frutifica em julho.

Nome popular: agoniada.

Mimosa amnis-atri é reconhecida principalmente pelo seu peculiar padrão foliar e de ramificação. As suas folhas possuem um número elevado de folíolos (28 a 49 pares), todos do mesmo tamanho e inseridos ao longo da raque muito próximos um do outro $(0,2-0,3 \mathrm{~cm})$. Os seus ramos são pouco ramificados e suas ramificações geralmente são observadas quando a planta atinge pelo menos 1,5 $\mathrm{m}$ de altura.

Barneby (1991) citou a presença de flores unissexuais em M. amnis-atri, porém todos os materiais examinados apresentam apenas flores bissexuais. Portanto, preferiu-se aqui descrever as flores como bissexuais já que este foi o tipo observado nos indivíduos estudados.

A validade desta espécie e a sua relação com M. gemmulata foi trata como incerta por Barneby (1991). Para este autor, as diferenças observadas entre estes táxons poderiam ser tratadas como extremo de variação morfológica dentro de M. gemmulata e que era necessário uma análise cuidadosa dos frutos de $M$. amnis-atri, não observado por ele, para esclarecer os limites destas 


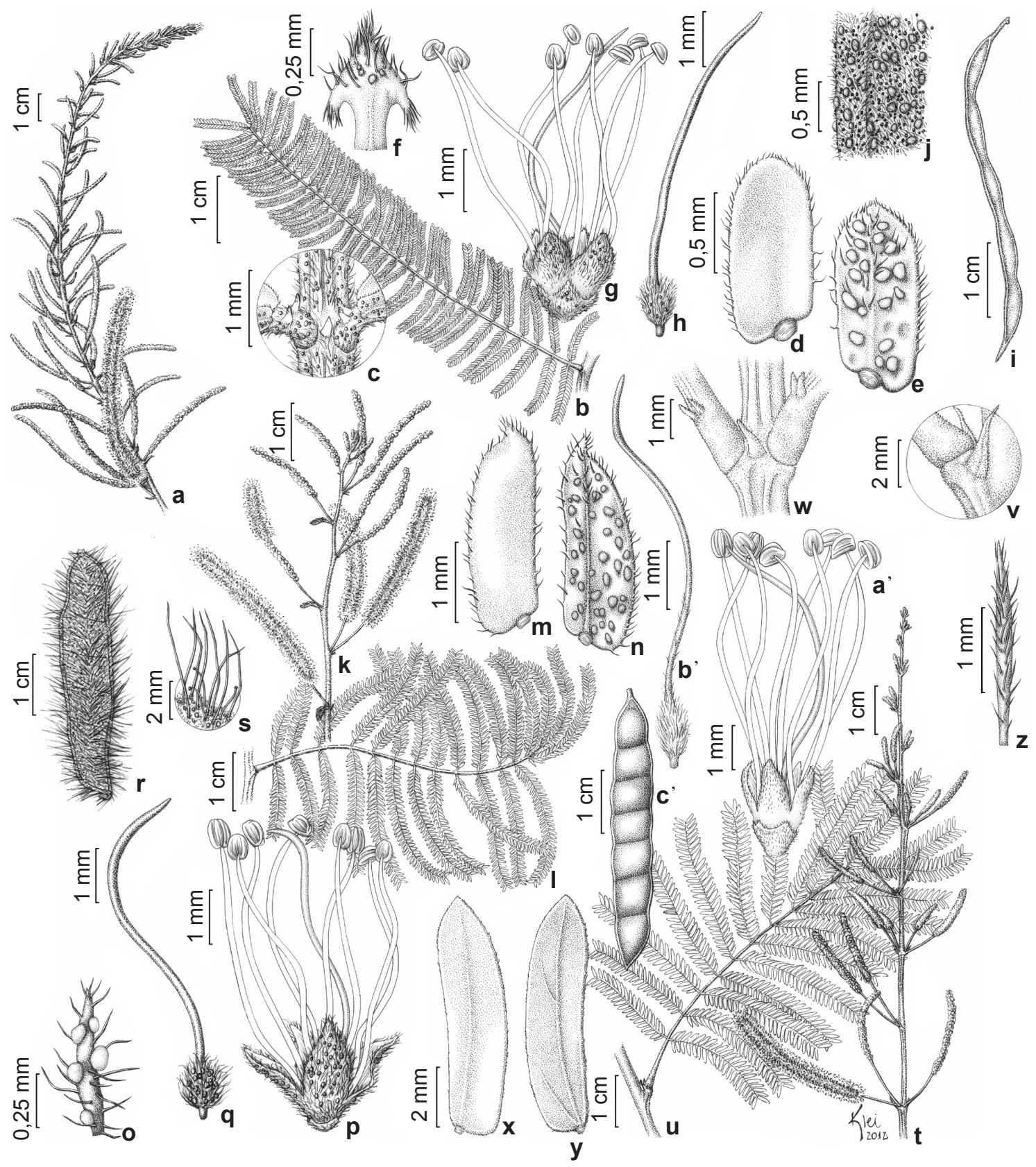

Figura 2 - a-j. Mimosa amnis-atri - a. inflorescência; b. folha; c. detalhe da raque foliar mostrando a espícula e os parafilídios; d. foliólulo, face adaxial; e. foliólulo, face abaxial; f. bractéola; g. flor; h. gineceu; i. fruto; j. detalhe do indumento do fruto. (J.S. Silva et al. 977). k-r. M. craspedisetosa - k. inflorescência; 1. folha; m. foliólulo, face adaxial; $\mathrm{n}$. foliólulo, face abaxial; o. bractéola; $\mathrm{p}$. flor; q. gineceu; r. fruto. s. detalhe do indumento do fruto (A. Fuentes \& G. Navarro 2195). t-c'. Mimosa dichroa-t. inflorescência. u. detalhe da folha. v. detalhe das estípulas. w. detalhe da raque mostrando a espícula e os parafilídios. x. foliólulo, face adaxial. y. foliólulo, face abaxial. z. bractéola. a'. flor. b'. ovário. c'. fruto. (t-b. H.G.P. dos Santos et al. 424; c. M.L. Fonseca et al. 1931). Figura 2-a-j. Mimosa amnis-atri-a. inflorescence; b. leaf; c. detail of leaf rachis, showing spicule and paraphyllidia; d. leaflet, adaxial surface; e. leaflet, abaxial surface; f. bract; g. flower; h. gynoecium; i. fruit; j. detail of fruit indumentum. (J.S. Silva et al. 977). k-r. M. craspedisetosa-k. inflorescence; 1. leaf; m. leaflet, adaxial surface; n. leaflet, abaxial surface; o. bract; p. flower; q. gynoecium; r. fruit. s. detail of fruit indumentum. (A. Fuentes \& G. Navarro 2195). t-c'. Mimosa dichroa -t. detail of leaf; u. detail of leaf, v. detail of stipules; w. detail of leaf rachis, showing spicule and paraphyllidia; $\mathrm{x}$. leaflet, adaxial surface; y. leaflet, abaxial surface; z. bract; a'. flower; b'. ovary; c'. fruit. (t-b. H.G.P. dos Santos et al. 424; c. M.L. Fonseca et al. 1931). 
espécies. Após uma avaliação cuidadosa dos frutos e das demais estruturas, estamos confirmando, neste trabalho, $M$. amnis-atri como uma espécie válida. Uma discussão mais completa a respeito das diferenças entre estas espécies é apresentada nos comentários de $M$. gemmulata.

Material examinado: BRASIL. GOIÁS: Chapadão do Céu, Parque Nacional das Emas, 17.V.1990, fl., G.F. Guala \& T.S. Figueiras 1376 (IBGE, NY); Mineiros, 9.IV.2011, fl., J.S. Silva et al. 976 (UEC), idem, 9.IV.2011, fl., J.S. Silva et al. 977 (UEC).

3. Mimosa apodocarpa Benth., Trans. Linn. Soc. London 30: 415. 1875. Tipo: Brazil, provinciae Goyaz, inter Funil et S. João, Burchell 9003 (Holótipo: foto K [Hb. Hook]! = NY Neg. 11662; Isótipos: $\mathrm{GH}, \mathrm{NY}$ !, P).

Mimosa xavantinae Barneby, Mem. New York Bot. Gard. 65: 151-152. 1991. Tipo: Brazil. Mato Grosso, Serra do Roncador, ca $60 \mathrm{~km} \mathrm{n}$. of Xavantina, 550 m, 6 Jun 1966, H.S. Irwin et al. 16677 (Holótipo: UB!; Isótipos: G, K!, LE, NY!, R!), syn. nov.

Fig. 3

Árvore a arvoreta 2-6 m alt.. Ramos inermes ou esparsadamente aculeados, glabrescentes, puberulento-tomentosos, castanhos. Acúleos internodais, retos a recurvados. Tricomas simples entremeados por glândulas sésseis, lentiformes, amarelo-opacas a acobreadas distribuídos no pecíolo, face abaxial dos foliólulos, bractéolas, lacínias da corola, ovário e frutos. Estípulas $3-5 \times 0,2-1,4 \mathrm{~mm}$, lanceoladas, triangulares a subuladas, não ciliada-glandulares. Folhas 12-19 pares de folíolos crescentes; pecíolo $1-3 \mathrm{~cm}$; raque 5,5-16 cm compr., interrompida ou não entre cada par de folíolos por espícula; segmento da raque $0,4-1,5 \mathrm{~cm}$ compr.; foliólulos 25-38 pares, decrescentes proximalmente; ráquila 3-9,5 cm compr., sulcada a cilíndrica; lâmina 2-10 × 0,5-3 mm, cartácea, reta ou ligeiramente arqueada para a frente, oblonga a ligeiramente lanceolada, base arredondada a truncada, ápice arredondado a ligeiramente agudo, margem não revoluta, ciliada, discolor, face adaxial verdeescuro, glabra, face abaxial verde-oliva, glabra a pilosa, 1-(2)-nervada. Pedúnculo 0,9-3 mm compr.; brácteas ausentes. Espigas 5-9,5 × 0,4 cm, congestas, solitárias a 2-3-fasciculadas, reunidas em panículas terminais; inflorescências latentes ausentes; bractéolas persistentes, menores que o botão floral, $0,5-1 \times 0,3-0,5 \mathrm{~mm}$, obtruladas, lanceoladas a oblanceoladas, não ciliadaglandulares. Flores tetrâmeras, bissexuadas, sésseis; cálice $0,5-0,8 \mathrm{~mm}$ compr., cupuliforme, não resinoso, velutino; corola 1-2 $\mathrm{mm}$ compr., campanulada, não resinosa, velutina, lacínias eretas; filetes 5-8 mm compr., livres, brancos; ovário 1-1,2 mm compr., séssil, velutino a piloso; estilete 5-6 mm compr.. Craspédios 5-11 $\times$ 0,9-1,5 cm, cartáceos, 6-15-articulados, sésseis, lineares a oblongos, base atenuada a arredondada, ápice mucronado a mucronulado, glabrescentes a puberulentos, castanhos; artículos quadrangulares, compressos, lustrosos; réplum reto a ligeiramente constricto entre os artículos, 0,6-0,7 $\mathrm{mm}$. Sementes 4-5 × $4 \mathrm{~mm}$, ovais, marrons.

Distribuição geográfica e habitat: Mimosa apodocarpa ocorre nos estados de Goiás, Mato Grosso e Mato Grosso do Sul, geralmente associada à vegetação de cerrado, entre 90 a 900 m. Barneby (1991) citou registro desta espécie para o Paraguai, no entanto nenhuma coleta proveniente deste pais foi analisada neste estudo.

A espécie é caracterizada pelas folhas compostas por 12 a 19 pares de folíolos e 25 a 38 pares de foliólulos retos ou ligeiramente arqueados para a frente, e pelas amplas panículas terminais de espigas sésseis a curto-pendunculadas, que atingem todas simultaneamete à antese. O indumento constituído por tricomas simples entremeados por glândulas, nesta espécie, reveste apenas o pecíolo, face abaxial dos folíolos, corola, ovário e fruto. Os frutos exibem as suturas dos artículos bem marcantes e com coloração mais clara do que a dos artículos.

Nos comentários de Mimosa apodocarpa, Barneby (1991) ressaltou que esta espécie é semelhante a $M$. xavantinae e que difere desta apenas por possuir foliólulos menores e cálice com maior comprimento. Assim, M. apodocarpa apresentaria foliólulos com 3-5 × 0,7-1,2 mm e cálice com 0,7-1 mm de comprimento, enquanto em M. xavantinae os foliólulos teriam (5.5-)6-10 $\times 1.3-3 \mathrm{~mm}$ e o cálice seria menor que $0,5 \mathrm{~mm}$. No entanto, dentre os espécimes analisados, estes intervalos não apresentaram descontinuidade. Dessa forma, não existem padrões nas dimensões dos foliólulos e do cálice consistentes para sustentá-las como duas entidades distintas. Sendo assim, propõe-se no presente trabalho a sinonimização de $M$. xavantinae em $M$. apodocarpa.

Acreditamos que a diferença no tamanho dos foliólulos, ressaltada por Barneby (1991), trata-se de um reflexo da coleta de materiais em 


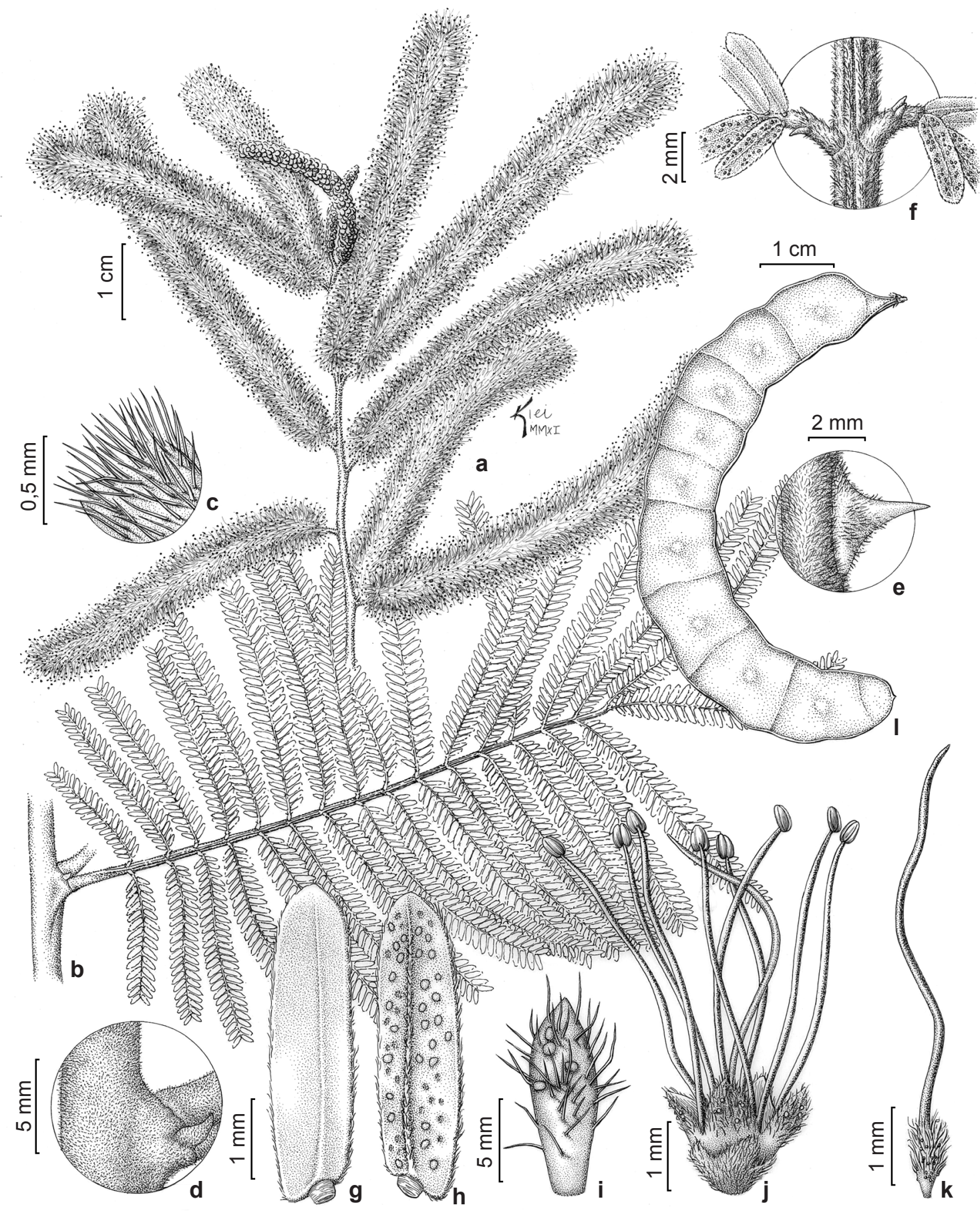

Figura 3 - Mimosa apodocarpa - a. ramo florido; b. folha; c. detalhe do indumento dos ramos; d. detalhe da estípula; e. detalhe do acúleo; f. detalhe da raque foliar mostrando os parafilídios; g. foliólulo, face adaxial; h. foliólulo, face abaxial; i. bractéola; j. flor; k. gineceu; 1. fruto. (a-k. J.W. Grear et al. 14939; 1. A.L.B. Sartori et al. 599).

Figure 3 - Mimosa apodocarpa - a. flowering branch; b. leaf; c. detail of indumentum of the stems; d. detail of stipule; e. detail of aculei; f. detail of leaf rachis, showing paraphyllidia; g. leaflet, adaxial surface; h. leaflet, abaxial surface; i. bract; j. flower; k. gynoecium; 1. fruit. (a-k. J.W. Grear et al. 14939; 1. A.L.B. Sartori et al. 599). 
diferentes estágio de desenvolvimento. De fato, o número e tamanho dos foliólulos geralmente varia de acordo com a posição das folhas na planta. As folhas de ramos jovens e estéreis são maiores do que aquelas que se desenvolvem associadas com as inflorescências.

Do grego, apodocarpa (apodo = pé; carpa = fruto) foi provavelmente utilizado em alusão aos seus frutos que são sésseis.

Material selecionado: BRASIL. GOIÁS: Posse, Rio do Prata, 9.IV.1966, fl., H.S. Irwin et al. 14548 (K, NY, MBM, MO, SPF, US). MATO GROSSO: Barra do Garça, divisa da cidade de Xavante com o Rio das Mortes, 26.VIII.1968, fr., G. Eiten \& L.T. Eiten 8359 (US). MATO GROSSO DO SUL: Alcinópolis, $54 \mathrm{Km}$ de Alcinópolis, 30.VI.2001, fr., A.L.B. Sartori et al. 599 (HMS, UEC). TOCANTINS: Arraias, TO $50 \mathrm{em}$ direção a Campos Belos, 12.V.2012, fr., J.S. Silva et al. 1174 (CEN, HUNEB, UEC); idem, 12.V.2012, fr., J.S. Silva et al. 1177 (CEN, HUNEB, UEC); Campos Belos, TO 50 em direção a Arraias, 8.V.2012, fr., J.S. Silva et al. 1105 (CEN, HUNEB, UEC).

4. Mimosa arenosa (Willd.) Poir., Encycl. Suppl. 1: 66.1810. Tipo: sob Mimosa arenosa (Willd.) Poir. var. arenosa.

Fig. 4

Arbusto a arvoreta 2-12 $\mathrm{m}$ alt.. Ramos inermes ou aculeados, glabrescentes a tomentosos, castanhos a acinzentados. Acúleos internodais, retos a ligeiramente incurvados, com base larga. Tricomas simples esbranquiçados, às vezes, entremeados por esparsos tricomas glandulares sésseis a curto-estipitados, alaranjados a avermelhados, distribuídos nos ramos, raque foliar, eixo das inflorescências e frutos. Estípulas $2-7 \times 0,2-0,6 \mathrm{~mm}$, triangulares, não ciliadaglandulares. Folhas $4-14$ pares de folíolos crescentes; pecíolo $0,6-1,5 \mathrm{~cm}$; raque $2,5-8$ $\mathrm{cm}$ de compr., interrompida ou não entre cada par de folíolo por espícula; segmento da raque 0,5-1,4 cm compr.; foliólulos 9-42 pares, decrescentes proximalmente; ráquila 1,5-6,5 cm compr., cilíndrica a sulcada; lâmina 3-7 $\times$ 1-2 mm, membranácea, oblonga, base oblíqua a arredondada, ápice agudo, margem não revoluta, discolor, face adaxial verdeescuro, pubescente a tomentosa, face abaxial verde-oliva, pubescente a tomentosa, sem pontuações glandulares ou glândulas sésseis, 2-3-nervada, apenas uma das nervura atinge o ápice. Pedúnculo 0,8-1 cm compr.; brácteas ausentes. Espigas 3-7 ×0,3-0,4 cm, congestas, solitárias a 2-fasciculadas, reunidas em panículas terminais nos ramos desfolhados ou nas axilas de folhas totalmente desenvolvidas; inflorescências latentes ausentes; bractéolas persistentes, menores que o botão floral, $1-7 \times 0,2-0,4$ $\mathrm{mm}$, oblanceoladas a elipíticas, não ciliadaglandulares. Flores tetrâmeras, bissexuadas, sésseis ou curto-pediceladas; cálice 0,3-0,5 mm compr., cupuliforme, ciliado, pubescente; corola 1,5-3 mm compr., campanulada, glabra a pubescente nas lacínias, lacínias eretas ou reflexas; filetes 5-7 mm compr., livres, brancos; ovário 0,9-1 mm compr., estipitado, estípite ca. 0,2 mm, glabro; estilete 5-6 mm compr.. Craspédios 2,5-6 × 0,4-0,6 cm, cartáceos, compressos, 5-8-articulados, estipitados, estípite 6-8 mm, oblongos a lineares, base atenuada, ápice mucronulado, glabros a glabrescentes, castanhos; artículos quadrangulares; réplum reto, ca. 0,5 mm. Sementes 3-4×2-3 mm, elipsoides, marrons.

Mimosa arenosa apresenta folhas com 4 a 14 pares de folíolos, face abaxial dos foliólulos sem pontuações glandulares ou glândulas sésseis, espigas agrupadas em panículas terminais desenvolvendo-se em ramos desfolhados ou nas axilas de folhas totalmente desenvolvidas, flores brancas, políades com oito grãos de pólen e frutos estipitados, compressos. Estes caracteres a aproxima de $M$. acutistipula, $M$. ophthalmocentra e M. urandiensis. No entanto, essas espécies podem ser diferenciadas, principalmente pelo comprimento das folhas, número de folíolos, forma do cálice e forma e indumento do ovário.

Com base no formato dos acúleos, presença ou ausência de espículas, número de nervuras dos folíolos associados à distribuição geográfica, Barneby (1991) estabeleceu três variedades para $M$. arenosa, a saber: M. arenosa var. arenosa, $M$. arenosa var. lysalgica Barneby e $M$. arenosa var. leiocarpa (DC.) Barneby. Segundo Barneby (1991) a var. lysalgica poderia ser diferenciada da variedade típica pelos acúleos antrorsos (vs. recurvados), 12 a 15 pares de folíolos (vs. 15-27) e corola puberulenta ( $v s$. glabra). No entanto, através de um estudo detalhado pôde-se notar que as caracterícticas para diferenciação da var. lysalgica e var. arenosa não são constantes entre as suas populações e apresentam sobreposições, sendo observados indivíduos da var. lysalgica com acúleos variando de retos a recurvados e com nove a dezoito pares de folíolos. Dessa forma, não se justifica a manutenção da var. lysalgica e por isso está sendo incluída aqui na sinonímia 


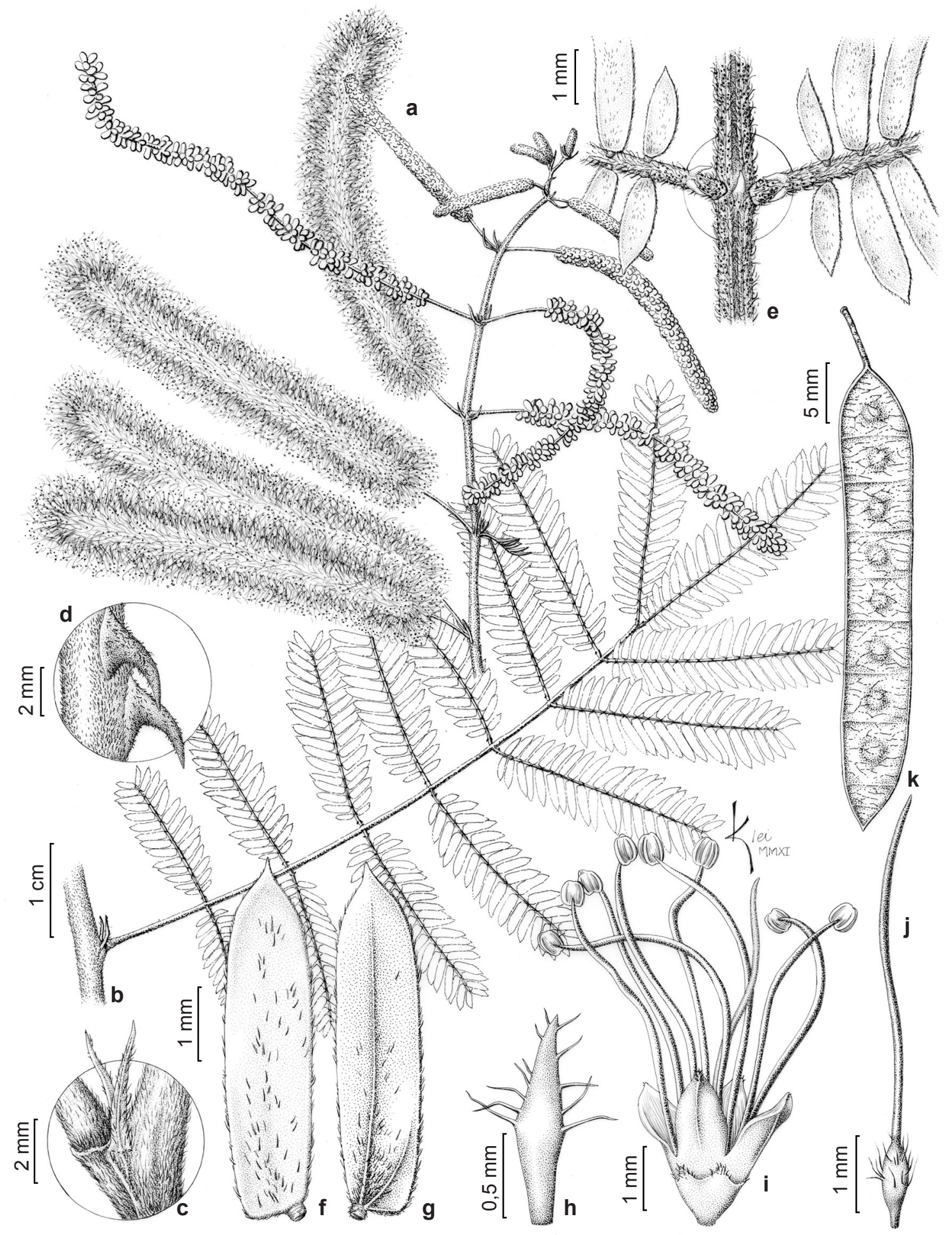

Figura 4 - Mimosa arenosa var. arenosa - a. ramo florido; b. folha; c. detalhe das estípulas; d. detalhe dos acúleos; e. detalhe da raque foliar mostrando a espícula e os parafilídios; f. foliólulo, face adaxial; g. foliólulo, face abaxial; h. bractéola; i. flor; j. gineceu; k. fruto. (a-j. R.M. Harley et al. 23006; k. R. Pereira \& J. Semir 1129).

Figure 4 - Mimosa arenosa var. arenosa - a. flowering branch; b. leaf; c. detail of stipules; d. detail of aculei; e. detail of leaf rachis, showing spicule and paraphyllidia; f. leaflet, adaxial surface; g. leaflet, abaxial surface; h. bract; i. flower; j. gynoecium; k. fruit. (a-j. R.M. Harley et al. 23006; k. R. Pereira \& J. Semir 1129). 
da var. arenosa. A ausência de espícula, os parafilídos ascendentes e os folíolos 3-4-nervados, características não observadas em populações da var. arenosa, levou Barneby (1991) a propor a var. leiocarpa. Como esses caracteres são constantes e descontínuos, permitindo assim o pronto reconhecimento dessas variedades, estas estão sendo mantidas aqui como variedades válidas.

\section{Chave para Identificação das variedades de Mimosa arenosa (Willd.) Poir.}

1. Raque interrompida entre cada par de folíolos por uma espícula; foliólulos 9-18 pares (maior folíolo), 1-2-nervados, com uma das nervuras atingido o ápice, mas não ramificada; flores predominantemente sésseis. 4.1. var. arenosa

1'. Espículas ausentes; foliólulos 25-42 pares (maior folíolo), 3-4-nervados, com uma das nervuras atingido $\mathrm{o}$ ápice e frequentemente ramificada; flores predominantemente curto-pediceladas $(0,2-0,3 \mathrm{~mm}) \ldots \ldots$. 4.2. var. leiocarpa

4.1 Mimosa arenosa (Willd.) Poir. var. arenosa, Encycl. Suppl. 1:66. 1810. Acacia arenosa Willd., Sp. Pl. 4: 1600. 1806. Tipo: Habitat ad Caracas in ripis arenosis fluviorum. Bredemeyer s.n. (Holótipo: B-W 19134-010; Isótipo: W!).

Mimosa malacocentra (Mart.) Benth., Trans. Linn. Soc. London 30: 415. 1875. Tipo: In monte Corcovado... in sylvis Catingas dictis pronvinciae mediterraneae Bahiensis frequens..." (Holótipo: Heb. Mart. 143, BR; Isótipos: BM, E, G, K!, M, NY!, W).

Acacia malacocentra Mart., Nov. Gen. Sp. Pl. 106. 1837.

Mimosa malacocentra var. angustifolia Benth., Fl. Bras. 15 (2): 360. 1876. Tipo: prope Rio de Janeiro, Burchell 2783 (Lectótipo: K!, designado por Barneby [1991: 128]= NY Neg. 11661; Isolectótipo: $\mathrm{GH})$, syn. nov.

Mimosa xantholasia Benth., London, J. Bot. 5:88. 1846. Tipo: Venezuela, Funcke 383 (Holótipo: K!; Isótipo: $\mathrm{G})$.

Mimosa fasciculata var. ernestiana Kuntze, Rev. gen. Pl. 1: 198. 1891. Tipo: “....von Professor Ernst in Caracas als Acacia fasciculata bestimmt... La Guayra" (Lectótipo: O. Kuntze 1194, coletado em 7.V.1874, fl., La Guayara [La Guaira, Venezuela], NY!, primeiro passo designado por Barneby 1991: 129, segundo passo lectótipo designado aqui).

Mimosa arenosa var. lysalgica Barneby, Mem. New York Bot. Gard. 65: 125-126. 1991. Tipo: Brasil, Minas Gerais, Filixlândia, $30 \mathrm{Km}$ w de Curvelo, 750m, 22 Feb 1975, fl., W.R. Anderson et al. 11523 (Holótipo: MBM!; Isótipos: K!, NY!, R!, US!), syn. nov.

Distribuição geográfica e habitat: ocorre em áreas secas do Brasil, Porto Rico, Venezuela, onde forma geralmente densas populações. No Brasilé encontrada em toda região Nordeste estendendose até o estado de Minas Gerais, sendo cultivada ainda em São Paulo (Piracicaba). Mimosa arenosa var. arenosa cresce em áreas de floresta seca, sob solos arenosos com ou sem afloramentos rochosos, em altitudes de até $3000 \mathrm{~m}$. É uma planta que, no Brasil, ocorre principalmente como invasora de regiões antropizadas, como beira de estradas e rodovias, áreas de cultivo abandonadas e próximo a habitações. Ocasionalmente é observada em regiões sujeitas a inundações periódicas.

Fenologia: Floresce e frutifica praticamente o ano inteiro.

Nome popular: angico-vermelho, angicoverdadeiro, calumbí-branco, calumbi-d'égua, calumbí-roxo, calumbí-preto, espinheiro-branco, guarucaia, jurema, jurema-branca, paricá, naraulí e cují (Venezuela).

Mimosa fasciculata var. ernestiana foi descrita por Kuntze (1891), com base em uma coleção oriunda de La Guaira (Venezuela). No entanto, na obra orignal não consta nenhuma informação sobre o espécime tipo (nome do coletor, número de coleta e herbário no qual o mesmo encontra-se depositado). Barneby (1991) cita o espécime O. Kuntze 1194 depositado em NY, como sendo o holótipo de $M$. fasciculata var. ernestiana. A partir disso, considera-se que a escolha de Barneby é o primeiro passo da lectotipificação e o segundo passo é aqui designado.

Outra correção aqui realizada foi do coletor do holótipo de Mimosa xantholasia citado por Barneby (1991) como sendo Funcke \& Schlim 383. No entanto, tanto no protólogo como no espécime depositado em $\mathrm{K}$ a coleta realizada na Venezuela é atribuída apenas a Heinrich Funcke. 
No presente trabalho, Mimosa malacocentra var. angustifolia Benth., incluída na sinonímia de M. acutistipula por Barneby (1991) é considerada um sinônimo taxonômico de $M$. arenosa, uma vez que apresenta o mesmo conjunto de características diagnósticas das populações de $M$. arenosa var. arenosa.

Material selecionado: BRASIL. ALAGOAS: Arapiraca, 18.VII.1981, fl., G.L. Esteves \& V.F. Ferreira 509 (IPA). BAHIA: Aporã, ca. $12 \mathrm{Km}$ de Crisópolis na estrada para Acajutiba, 26.VIII.1996, fl. e fl., L.P. de Queiroz \& N.S. Nascimento 4663 (HUEFS, K). CEARÁ: General Sampaio, 8.VII.2005, fr., J.R. Lemos \& R.N.V. Silva 380 (HUEFS). MINAS GERAIS: Corinto, Fazenda do Diamante,15.IV.1931, fl., Y. Mexia 5624 (K, US). PARAÍBA: Alagoa Grande, X.1993, fl., M.F. Angra 1750 (K). PERNAMBUCO: Caruaru, s. loc., 28.VI.2011, fl. e fr., J.S. Silva \& P.P.A. Silva 978 (UEC). RIO DE JANEIRO: Cabo Frio, Arraial do Cabo, fl., II.1951, S. Vianna 4049 (R, US). RIO GRANDE DO NORTE: Mossoró, Alagoinha, Fazenda Rafael Fernandes, 13.IX.2006, fr., M.L. Silva et al. 154 (PEUFR, HUEFS). SERGIPE: Nossa Senhora Aparecida, SE-175, 23.VIII.2005, fl., D.S. Carneiros-Torres et al. 465 (HUEFS). PORTO RICO. FARJADO: Bo. Quebrada Farjado, 26.I.1996, fl., F. Axelrod \& L. Pérez 9676 (MO). VENEZUELA. ANZOATEGUI: Freites, $10 \mathrm{Km} \mathrm{SW}$ of Mundo Nuevo along road to El Saman, 4.XII.1981, fr, D. Gerrit \& $G$ Angel C. 20008 (MO). BOLÍVAR: Carretera PiarPto Osdaz, 8.XI.1963, fl., B. Tiujillo 5970 (MO). GUARICO: 23 km NE de Chagauranas, 15.XI.1973, fr., G. Davidese 4224 (MO). LARA: Bajo, 6.I.1929, fl. fr., H. Pittier 13095 (MO); rodovia Quibor-Sanare, 5.VIII.1982, fl, T.B. Croat 54670 (MO).

4.2 Mimosa arenosa var. leiocarpa (DC.) Barneby, Mem. New York Bot. Gard. 65: 126. 1991. Mimosa leiocarpa DC., Prodr. 2: 429. 1825. Tipo: ad Sancatam-Martham Bertero (Lectótipo: Bertero s.n., G, primeiro passo lectótipo designado por Barneby 1991: 126 = F Neg. 6983!, segundo passo lectótipo designado aqui).

Acacia nutans Spreng., Syst. veg. 3: 141. 1826. Tipo: Ad fl. Magdalena [Colombia], Bertero s.n. (Holótipo: aparentemente um isótipo de Mimosa leiocarpa, mas este não foi localizado nos herbários visitados).

Mimosa caudero Cárdenas, Ernstia 40:15, Figs. 7,8. 1986. Tipo: Venezuela: Edo Lara: a lo largo de la quebrada La Esperanza em Sique-Sique y Baraguá, 350 m.s.m., 29 Aug 1981, M. Ponce \& B. Trujillo 340 (Holótipo: MT).

Distribuição geográfica e habitat: esta variedade apresenta um padrão de distribuição disjunto entre o norte da Colômbia (Magdalena), norte da Venezuela, Nicarágua e México. Mimosa arenosa var. leiocarpa cresce em áreas de floresta estacional decidual, sobre solos arenosos, argilosos e com afloramento rochosos, em baixas altitudes (30 a $500 \mathrm{~m}$ ). Pode também ser encontrada próxima a cursos d'água (Oaxaca) e em áreas degradadas, como beira de estradas e rodovias.

Fenologia: Flores foram observadas em fevereiro, junho a agosto, outubro a dezembro e frutos de janeiro a março.

Nome popular: ceiba e tepehuiste

Mimosa arenosa var. leiocarpa é predominantemente arvoreta atingindo até 12 $\mathrm{m}$ de altura, com ramos raramente aculeados e a ráque e ráquila, em geral, mais delgadas do que a variedade típica. Além disso, as bractéolas são maiores (4-7 mm compr. vs. 1-4 mm na var. arenosa) e as flores são, em sua maioria, curtopediceladas.

Mimosa leiocarpa quando descrita por De Candolle (1825), foi baseada no espécime "ad Sancatam-Martham, Betero", que é um sintipo, pois não foi citado o herbário onde espécime está depositado e, além disso, porque existem diversos espécimes coletados por Bertero e sem numeração nos diferentes herbários. Assim, considera-se aqui que o primeiro passo da lectotificação foi inferencialmente realizada por Barneby (1991) quando ele cita como holótipo o espécime depositado no herbário G e, o termo está aqui sendo corrigido para lectótipo em um segundo passo.

Vale ressaltar que, infelizmente, não tivemos acesso ao holótipo de Mimosa caudero. No entanto, analisamos o protólogo e a maioria dos parátipos depositados em NY (Cárdenas 2913, 3010, 2895, 2897, 2913), o que permite seguramente manter esta espécie na sinonímia de M. arenosa var. leiocarpa.

Do latim, leiocarpa (leio = macio, liso, plano; carpa $=$ fruto) refere-se provavelmente aos seus frutos compressos.

Material selecionado: COLÔMBIA. LA GUAJIRA: Maicao, 19.IV.1981, fl., O. Arboleda et al. 654 (MO). MAGDALENA: Santa Marta, Gaira, 30.XI.1966, R. Romero-Castañeda 10479 (MO, NY). MÉXICO. JALISCO: La Huerta, Rancho Cuixamala, 11.II.1992, fr., L. Ricco \& S. Vázquez 1058 (K); GUERRERO: Petatlan, Cerro Huamilule, 23.VIII.1989, fl., N. Diego 5394 (K). NICARÁGUA. MANAGUA: Puetas ViejasSanta Juana, 8.VI.1983, fl., M. Araquistain 3565 (MO). 
VENEZUELA. FALCÓN: 37 km n.w. de Churuguava, 31.I.1985, fl., C.D. Johnson 3873-85 (NY). LARA: Carora-Trentino, 16.I.1928, fr., H. Pittier 12615 (MO).

5. Mimosa caccavariana J. Santos-Silva \& A.M.G. Azevedo, nom. \& stat. nov.

Mimosa gemmulata var. occidentalis Barneby, Mem. New York Bot. Gard. 65: 151. 1991, non Rose \& Britton, 1928. Tipo: Brasil, Mato Grosso, Alto Garça, rod. BR 364, 15 Nov 1973, G. Hatschbach \& C. Koczicki 33237 (Holótipo: NY!).

Fig. 5a-g

Arbusto a subarbusto 1-2,5 m alt.. Ramos inermes, puberulentos, castanhos. Tricomas simples esbranquiçados, entremeados por glândulas sésseis, esféricas, amarelo-translúcidas distribuídos nos ramos, raque foliar, face abaxial dos foliólulos, inflorescências, bractéolas, flores e frutos. Estípulas 2-4 × 0,2-0,4 $\mathrm{mm}$, lanceoladas, não ciliada-glandulares. Folhas 26-37 pares de folíolos ligeiramente crescentes; pecíolo 0,6-1 cm compr., sulcado, puberulento; raque $13-15 \mathrm{~cm}$ compr.; espículas ausentes; segmento da raque $0,3-1 \mathrm{~cm}$ compr.; foliólulos 33-54 pares, decrescentes proximalmente; ráquila 3,5-4,2 cm compr., canaliculada; lâmina 3-4,5 × 0,7-1 mm, cartácea, oblonga, base arredondada, ápice discretamente agudo, margem não revoluta, ciliada, discolor, face adaxial verde-escuro, opaca, glabra a puberulenta, face abaxial verde-oliva, glabra, 1-nervada, nervuras mais evidentes na face abaxial e atingindo o ápice. Pedúnculo 1,5-3 cm compr.; brácteas ausentes. Espigas 6,5-8 × 0,4 cm, congestas, 2-fasciculadas, em ramos contemporâneos, desfolhados ou menos frequente nas axilas de folhas jovens; inflorescências latentes ausentes; bractéolas persistentes, menores que o botão floral, $0,8-1 \times$ $0,2-0,3 \mathrm{~mm}$, lanceoladas, não ciliada-glandulares. Flores tetrâmeras, bissexuadas, sésseis; cálice 0,5-0,6 mm compr., cupuliforme, puberulento; corola 1,8-2 mm compr., campanulada, glabra, lacínias eretas; filetes 5-6 mm compr., livres, róseos; ovário $\pm 1 \mathrm{~mm}$ compr., séssil, viloso; estilete $4-5 \mathrm{~mm}$ compr.. Craspédios 3,5-5 × 0,6-0,7 cm, cartáceos, 6-8-articulados, sésseis, oblongos, base atenuada, ápice cuspidado, glabros, densamente revestido por glândulas, castanhos; artículos quadrangulares, elevados na região das sementes; réplum constricto entre os artículos, 0,5-0,6 mm. Sementes 3-3,5 × 3-3,5 mm, orbiculares, marrons.

Distribuição geográfica e habitat: Mimosa caccavariana distribui-se nos estados de Goiás e Mato Grosso, em áreas de cerrado e campocerrado. Tanto em Goiás quanto em Mato Grosso, as populações da espécie correm grande risco de serem localmente extintas devido à destruição de seus habitats causada pelo aumento das áreas destinadas às plantações de soja e milho.

Fenologia: Flores foram observadas em maio e julho e fruto em janeiro e abril.

Nome popular: angiquinho.

Pode ser confundida com $M$. hebecarpa, no entanto, nesta espécie os folíolos variam de 10 a 21 pares, as espigas desenvolvem-se em ramos velhos desfolhados abaixo das folhas e os frutos são estipitados e tomentoso-vilosos.

Mimosa caccavariana foi tratada por Barneby (1991) como uma das variedades de M. gemmulata: M. gemmulata var. occidentalis Barneby. No entanto, existe um conjunto de características descontínuas que separa estes dois táxons, como o número de folíolos (26-37 pares vs. 9-21), tamanho da raque $(13-15 \mathrm{~cm} v s .4-10,5 \mathrm{~cm})$, da lâmina (3-4,5 mm vs. $1,2-2 \mathrm{~mm})$ e dos frutos $(3,5-5 \mathrm{~cm}$ vs. $1,7-3 \mathrm{~cm})$. As suas espigas desenvolvem-se em geral sobre ramos desfolhados acima da folhagem e as suas folhas estão esparsadamente distribuídas ao longo dos ramos, enquanto que em M. gemmulata as espigas crescem geralmente nas axilas de folhas jovens ou totalmente desenvolvidas e as suas folhas normalmente estão adensadamente no ápice dos ramos. A distribuição de $M$. gemmulata é mais ampla, ocorrendo no Brasil (BA, GO, MG, PE, PI) e na Venezuela, enquanto a de $M$. caccavariana foi verificada apenas na região centro-oeste do Brasil (GO).

No presente trabalho estamos, estabelecendo um novo nome para este táxon, considerando a existência de $M$. occidentalis Britton \& Rose (Britton \& Rose 1928). O epíteto caccavariana é uma homenagem à palinóloga Marta Caccavari, em reconhecimento a sua grande contribuição ao conhecimento da morfologia polínica de Mimosoideae.

Material selecionado: BRASIL. GOIÁS: Mineiros. 9.IV.2011, fl. e fr., J.S. Silva et al. 970 (UEC), idem, 9.IV.2011, fl. e fr., J.S. Silva et al. 973 (UEC).

6. Mimosa coruscocaesia Barneby, Brittonia 37: 128, fig. 2a-c, 1985. Tipo: Brasil, Bahia, Caiteté, Martius s.n. (Holótipo: M-006177, isótipo $\mathrm{G}=\mathrm{NY}$ Neg. 11832!).

Fig. 5h-p

Arbustos 1-4 m alt.. Ramos inermes, tomentosos a híspidos nos ramos jovens, castanhos. Tricomas medusiformes $0,8-2 \mathrm{~mm}$ compr., esparsos a densamente distribuídos, às vezes, caducos, ferrugíneos, entremeados por glândulas 


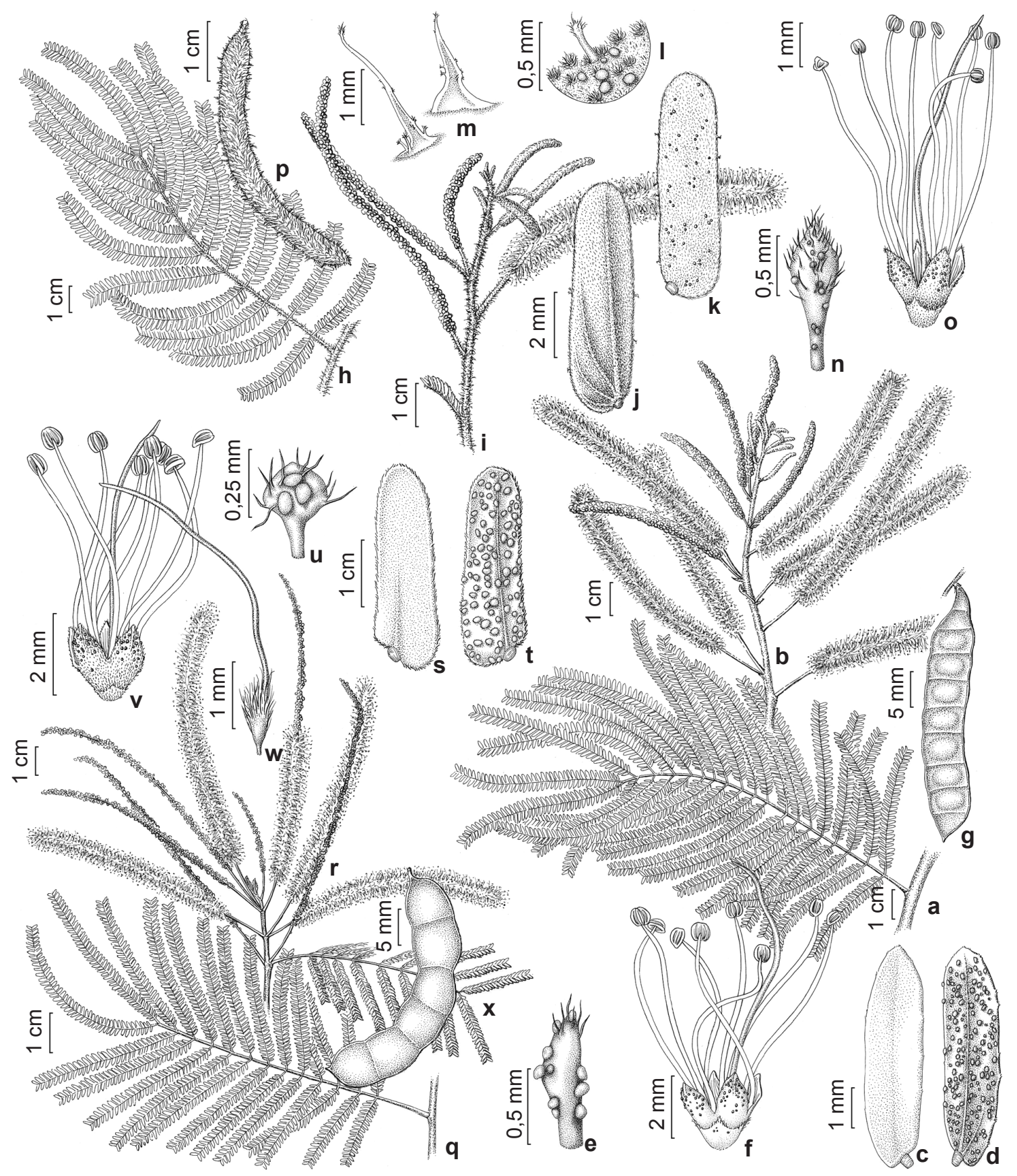

Figura 5 - a-g. M. caccavariana - a. folha; b. ramo florido; c. foliólulo, face adaxial; d. foliólulo, face abaxial; e. bractéola; f. flor. g. fruto. (J.S. Silva et al. 973). h-p. Mimosa coruscocaesia - h. folha; i. ramo florido; j. foliólulo, face abaxial; k. foliólulo, face adaxial; 1. detalhe do indumento; m. detalhe dos tricomas; n. bractéola; o. flor. p. fruto. (a-h. D. Alvarenga 89; i. M.F. Simon 324). q-x. M. gemmulata - q. folha; r. ramo florido; s. foliólulo, face adaxial; t. foliólulo, face abaxial; u. bractéola; v. flor; w. gineceu. x. fruto (q-r, s-w. S.A. Mori \& R. Funch 13387; x. G. Pereira-Silva et al. 3105).

Figure 5 - a-g. M. caccavariana - a. leaf; b. flowering branch; c. leaflet, adaxial surface; d. leaflet, abaxial surface; e. bract; f. flower; g. fruit. (J.S. Silva et al. 973). h-p. Mimosa coruscocaesia - h. leaf; i. flowering branch; j. leaflet, abaxial surface; k. leaflet, adaxial surface; 1. detail of indumentum; m. detail of trichomes; n. bract; o. flower. p. fruit. (h-i, j-o. D. Alvarenga 89; P. M.F. Simon 324). q-x. M. gemmulata - q. leaf; r. flowering branch; s. leaflet, adaxial surface; t. leaflet, abaxial surface; u. bract; v. flower; w. gynoecium; x. fruit. (q-r, s-w. S.A. Mori \& R. Funch 13387; x. G. Pereira-Silva et al. 3105). 
sésseis, lentiformes, amarelo-translúcidas a acobreadas e por curta camada de tricomas simples esbranquiçados, distribuídos nos ramos, pecíolos, raque foliar, eixo das inflorescências e frutos; tricomas estrelados sésseis no cálice ou entremeados por glândulas sésseis, lentiformes, amarelo-translúcidas a acobreadas na face abaxial dos foliólulos, bractéola e corola. Estípulas 1,3-2 $\times 0,5-0,8 \mathrm{~mm}$, lanceoladas a triangulares, não ciliada-glandulares. Folhas 8-14 pares de folíolos; pecíolo 1,3-1,6 cm compr.; raque (4-)5-10,5 cm compr., interrompida entre os pares de folíolos distais por espícula; segmento da raque 0,7-1,2 cm compr.; foliólulos 21-34 pares, decrescentes proximalmente; ráquila (4-)5,5-7 cm compr., cilíndrica; lâmina 5-8 × 1,8-2 mm, cartácea, oblonga a ligeiramente lanceolada, base oblíqua, ápice arredondado, margem não revoluta, às vezes, com tricomas medusiformes, discolor, face adaxial glauca, glabra a vilosa revestida por tricomas simples, face abaxial verde-oliva, puberulenta, 2-4-nervada. Pedúnculo 0,5-1,5 cm compr.; brácteas ausentes. Espigas (5-)8,5-10 × 0,4 cm, congestas, solitárias, nas axilas de folhas jovens ou totalmente desenvolvidas; inflorescências latentes ausentes; bractéolas persistentes, menores que o botão floral, 1,4-1,5 × 0,4-0,5 mm, obtruladas, não ciliada-glandulares. Flores tetrâmeras, bissexuadas, sésseis; cálice 1-1,6 mm compr., cupuliforme, puberulento; corola 2,3-2,5 mm compr., campanulada, puberulenta, lacínias eretas a reflexas; filetes 8-9 mm compr., livres, róseos; ovário 1-1,2 mm compr., séssil, seríceo; estilete 8-10 mm compr.. Craspédios 2-5,5 × 0,5-0,8 cm, cartáceo-coriáceos, subtúrgidos, 6-9-articulados, sésseis, oblongos, base atenuada a arredondada, ápice mucronado, puberulentos, vilosos a tomentos, marrons a ferrugíneos; artículos quandragulares; réplum reto, 0,6-0,7 $\mathrm{mm}$. Sementes 3-4 × 3-4 $\mathrm{mm}$, ovais, marrons.

Distribuição geográfica e habitat: Esta espécie foi verificada na região centro-sul da Bahia estendendo-se até o noroeste de Minas Gerais, em altitudes que variam de 750 a $1000 \mathrm{~m}$. É frequente ao longo do Rio Carinhanha, crescendo em áreas de caatinga, campo sujo, cerrado e carrasco, sobre solos arenosos quartzosos.

Fenologia: Flores foram observadas em janeiro, fevereiro, março, maio, julho, outubro, novembro e frutos em março, maio, junho, julho.

Nome popular: angiquinho

Mimosa coruscocaesia é uma das poucas espécies da série Leiocarpae s.l. com tricomas medusiformes e estrelados recobrindo as diferentes estruturas vegetativas e reprodutivas. Nesta espécie, os tricomas medusiformes são ferrugíneos e bem maiores do que em $M$. schomburgkii e $M$. trianae (0,8-2 mm vs. 0,2-0,3 mm). Os foliólulos são discolores com a face adaxial glauca e a abaxial verde oliva (quando secos). Ressalta-se que os tricomas aqui tratados como medusiformes foram denominados por Barneby (1991) de "plumulose setulae". No entanto, não adotamos este termo por ter sido verificado que as ramificações presentes nestes tricomas estão aglomeradas no ápice do estípite e não estão distribuídos no seu eixo central.

A presença de tricomas medusiformes nesta espécie conduziu Bentham (1876) a identificá-la erroneamente como $M$. cylindracea Benth. (série Lepidotae Benth. = Mimosa sect. Calothamnos), que tem flores isostêmones com filetes amarelos. Já as flores de Mimosa coruscocaesia são diplostêmones e seus filetes são róseos.

Dentre as espécies com filetes róseos, M. coruscocaesia é morfologicamente mais relacionada a $M$. gemmulata, todavia esta segunda espécie não possui tricomas medusiformes e seus foliólulos não apresentam a face adaxial glauca e a face abaxial verde oliva.

Material selecionado: BRASIL. BAHIA: Baianópolis, rodovia BA-242, 15.V.1997, fl. e fr., C.F.R. Cardoso et al. 34 (ASE, K, NY, UNB, UFS). MINAS GERAIS: Chapada Gaúcha. Parque Nacional Grande Sertão Vereda, 25.V.2012, fl. e fr., J.S. Silva \& H. Moreira 1186 (CEN, HUNEB, UEC); idem, 25.V.2012, fl. e fr., J.S. Silva \& H. Moreira 1187 (CEN, HUNEB, UEC).

7. Mimosa craspedisetosa Fortunato \& Palese, Candolle 54: 83-87, fig. 1, 1999, emend. J. SantosSilva \& A.M.G. Azevedo. Tipo: Bolívia. Santa Cruz, Cerro San Miguel, 19¹8'S, 60³9'W, alt. 700 m, 9 Mar 1989, L. Ramelle \& F. Mereles 2632 (Holótipo: foto G!; Isótipo: BAB).

Mimosa ferricola R.R. Silva \& A.M.G. Azevedo, Hoehnea 38 (1): 143-146. 2011. Tipo: Brasil. Mato Grosso do Sul, Ladário, Serra do Rabichão, 26 Fev 2004, R.R. Silva \& M.V. Silva 750 (Holótipo: UEC! Isótipos: COR, K), syn. nov. Fig. $2 \mathrm{k}-\mathrm{s}$

Arbusto 1-3 m alt.. Ramos aculeados, curtamente tomentosos, castanhos. Acúleos infranodais, distribuídos aos pares, retos a discretamente ascendentes, às vezes, estendendo-se para os entrenós. Tricomas simples esbranquiçados, entremeados por glândulas sésseis, lentiformes, douradas a alaranjadas, translúcidas, distribuídos 
nos ramos, folhas, face abaxial dos foliólulos, corola, ovário e fruto e por tricomas glandular-estipitados (0,4-1,5 mm) nos frutos e raramente nos folíolos. Estípulas $1-1,3 \times 0,2-0,3 \mathrm{~mm}$, lineares, com aspecto de espinho, não ciliada-glandulares. Folhas 6-17 pares de folíolos ligeiramente crescentes; pecíolo 0,6-1 cm compr.; raque 5-7,5 cm compr., interrompida entre cada par de folíolos por espícula; segmento da raque 0,4-0,5 cm compr.; foliólulos 9-33 pares, decrescentes proximalmente; ráquila $1,8-2$ cm compr., subcilíndrica; lâmina 2-2,5 × 0,5-0,7 $\mathrm{mm}$, membranácea, oblonga, base arredondada, ápice agudo, margem não revoluta, curtamente ciliada ou raramente ciliada-glandular, glabra, face adaxial resinosa, 1-nervada, nervura de difícil visualização. Pedúnculo 0,4-0,5 cm compr.; brácteas ausentes. Espigas 3-6 × 0,2 cm, laxifloras, solitárias a 2-fasciculadas, nas axilas de folhas jovens ou em ramos desfolhados; inflorescências latentes ausentes; bractéolas persistentes, menores que o botão floral, $0,8-1 \times 0,2-0,3 \mathrm{~mm}$, lineares, não ciliada-glandulares. Flores tetrâmeras, bissexuadas ou raramente unisexuadas, sésseis; cálice 0,3-0,4 mm compr., cupuliforme, resinoso, pubescente; corola 1-2 mm compr., campanulada, tomentosa, lacínias reflexas; filetes 6-7 mm compr., livres, róseos; ovário 0,8-1 mm compr., séssil, viloso com glândulas esparsas ; estilete 6-9 mm compr.. Craspédios 2,5-5 × 0,6-0,7 $\mathrm{cm}$, cartáceos, compressos, 5-6-articulados, sésseis, oblongos, base atenuada, ápice mucronado, híspidos entremeados por uma fina camada pubescente, castanhos; artículos quadrangulares ou retangulares; réplum reto ou discretamente constricto entre os artículos, ca. 0,5 mm, híspido. Sementes 3-4 × 3-4 $\mathrm{mm}$, ovais, castanho-escuras a enegrescidas.

Distribuição geográfica e habitat: Mimosa craspedisetosa é conhecida por poucas coletas oriundas do estado do Mato Grosso do Sul e do departamento de Santa Cruz na Bolívia. No Mato Grosso do Sul é encontrada apenas na Serra do Rabichão, onde cresce em bancada laterítica e em áreas brejosas sobre solos avermelhados ricos em minério de ferro, em baixas altitudes (220-230 m). Na Bolívia, M. craspedisetosa cresce em bosque seco e em áreas de pastagens associada a solos avermelhados, entre 400 e $700 \mathrm{~m}$ de altitude.

Fenologia: Flores foram observadas em fevereiro e frutos em junho e julho.

Mimosa craspedisetosa pode ser reconhecida por ser o único representante de Mimosa ser. Leiocarpae com frutos híspidos, cujo indumento é formado por tricomas simples e glandulares (sésseis e estipitados). Vegetativamente ou até mesmo em flores pode ser facilmente confundida com $M$. gemmulata. No entanto, esta espécie possui ramos inermes e os seus frutos são glabrescentes a vilosos. Além disso, $M$. gemmulata não possui glândulas estipitadas revestindo nenhuma das suas estruturas. Outra espécie morfologicamente próxima é $M$. amnis-atri, entretanto nesta os ramos são inermes, os folíolos são em maior número (28-41 pares) e os frutos são pubescentes.

Mimosa craspedisetosa foi publicada, após a revisão de Barneby (1991), por Fortunato \& Palese (1999) que a incluíram em Leiocarpae s.l. devido, principalmente, à presença de glândulas estipitadas no fruto. No protólogo, a sua descrição foi baseada em espécimes apenas com frutos. Portanto, neste trabalho estamos complementando sua descrição original.

Além disso, propõe-se aqui a sinonimização de M. ferricola R.R. Silva \& A.M.G. Azevedo em $M$. craspedisetosa, uma vez que através da análise da coleção-tipo e de coletas recentes, não restam dúvidas de que tratam-se de uma mesma entidade taxonômica. Ambos os táxons compartilham os ramos armados com acúleos infranodais distribuídos aos pares, face abaxial dos foliólulos revestidos por glândulas lentiformes, flores reunidas em espigas, frutos híspidos, revestido por tricomas simples e glandulares (sésseis ou raramente estipitados), principais características diagnósticas de $M$. ferricola. É interessante ressaltar que a coloração creme dos filetes referida no protólogo de $M$. ferricola, pode ter sido um equívoco dos coletores ou os mesmos podem ter visualizado flores senescentes. Normalmente, os filetes róseos mudam de cor à medida que envelhecem, tornandose esbranquiçados ou rosa claro.

Material examinado: BRASIL. MATO GROSSO DO SUL: Ladário, 8.VI.1994, fr., G. Hatschbach et al. 60807 (MBM). BOLIVIA. SANTA CRUZ: Cordillera, Parque Nacional Kaa Iya del Gran Chaco, 7.II.1998, fl., A. Fuentes \& G. Navarro 2195 (NY, USZ).

8. Mimosa dalyi Barneby, Brittonia 36: 249, fig. 1, 1984. Tipo: Bolívia, Santa Cruz, prov. Chiquitos, Santa Isabel, 20-25 Km SSE of Santiago de Chiquitos, 22 July 1983, D.C. Daly et al. 2269 (Holótipo: NY!; Isótipos: G, K, LPB, US!). Fig. 6 Arbusto a arvoreta 1,8-5 $\mathrm{m}$ alt.. Ramos inermes, puberulentos a glabrescentes, castanhos a enegrescidos. Tricomas simples esbranquiçados, 
entremeados por lepidotos, vermelho-amarronzados distribuídos nos ramos, folhas, inflorescências, flores e frutos. Estípulas 5-10 × 0,2 mm, lineares, não ciliada-glandulares. Folhas (16-)17-21 pares de folíolos decrescentes proximalmente; pecíolo $1-2 \mathrm{~cm}$ compr.; raque 11-15 cm compr.; espículas ausentes; segmento da raque $0,6-0,7 \mathrm{~cm}$ compr.; foliólulos (20-)30-47 pares, decrescentes proximalmente; ráquila (3,5-)4,0-4,5 cm compr., serreada; lâmina 1,5-3,5 × 0,5-0,9 mm, cartácea, oblonga, base oblíqua, ápice arredondado a discretamente agudo, margem não revoluta, ciliada, glabra, face abaxial sem pontuações glandulares ou glândulas sésseis, 3-4-nervada, nervuras mais evidentes na face abaxial sendo uma central e mais frequentemente duas submarginais todas podendo atingir ou não o ápice. Pedúnculo 0,5-1,3 cm compr.; brácteas ausentes. Espigas 5,5-12,5 × 0,4 cm, congestas, solitárias ou 2-3-fasciculadas, nas axilas de folhas jovens ou totalmente desenvolvidas; inflorescências latentes ausentes; bractéolas persistentes, menores que o botão floral, 0,9-1 ×0,1-0,2 mm, obtruladas a oblanceoladas, não ciliada-glandulares. Flores tetrâmeras, bissexuadas, sésseis; cálice $0,4-0,5 \mathrm{~mm}$ compr., cupuliforme, pubescente; corola 1-1,5 mm compr., campanulada, pubescente, lacínias eretas; filetes 8-10 mm compr., livres, róseos; ovário 0,9-1 mm compr., séssil, viloso; estilete 9-11 mm compr.. Craspédios 3,7-8 ×0,2-0,4 cm, cartáceos, lateralmente tetragonais, 5-10-articulados, sésseis, lineares, base atenuada, ápice agudo, puberulentos a glabrescentes, marrons; artículos quadrangulares ou retangulares, elevados na região das sementes; réplum convexo, ligeiramente constricto entre os artículos dando um aspecto submoniliformes ao fruto, 1-2 mm. Sementes 3,5-4 × $2 \mathrm{~mm}$, ovoides, marrons.

Distribuição geográfica e habitat: Mimosa dalyi foi citada por Barneby (1991) apenas para a Bolívia, mas encontramos uma coleta desta espécie oriunda do departamento de Amabay (Paraguai), onde cresce no topo da serra Sarambi. Na Bolívia é encontrada apenas no departamento de Santa Cruz, crescendo em vegetação de cerrado e cerradão (bosque baixo esclerofilo pluviestacional), sobre solos arenosos, em altitudes que variam de 225 a 400 m. Barneby (1991) mencionou que esta espécie é frequente na Bolívia, especialmente em áreas sob a influência dos rios Guaporé e Paraguai.

Fenologia: Flores são observadas em junho e novembro e frutos em junho.

Mimosa dalyi apresenta características bastante distintas das demais espécies de $M$. ser. Leiocarpae: tricomas lepidotos vermelho- amarronzados esparsadamente distribuídos nos ramos, folhas, inflorescências, flores e frutos. Nesta espécie, as folhas são composta por 17-20 pares de folíolos com (20-)30-47 pares de foliólulos por folíolo, a ráquila é sulcada e os filetes são róseos. Além disso, não possui espículas entre os folíolos e os foliólulos não ultrapassam mais que $3,5 \mathrm{~mm}$ de comprimento.

Mimosa insignis é a espécie mais próxima morfologicamente de M. dalyi. Ambas compartilham folíolos com mesmo número de nervuras (3-nervada), sem glândulas, ráquila serreada e frutos similares. No entanto, em $M$. insignis as folhas possuem de 7 a 10 pares de folíolos com 68-100 pares de foliólulos em cada folíolo, a ráquila é maior $(8-10,5 \mathrm{~cm})$, as espículas estão presentes entre todas os folíolos, os foliólulos são maiores (5-9 mm) e os filetes são brancos.

O epíteto espécifico foi dado em homenagem ao Dr. Douglas Daly, pesquisador do Jardim Botânico de Nova York, que coletou o holótipo. Material examinado: BOLÍVIA. SANTA CRUZ: Chiquitos, en la meseta de la Serrania del Mirador, 8.VI.2009, fl., D. Soto et al. 1119 (HUEFS, USZ); Nuflo de Chavez, Estancia San Miguelito, $200 \mathrm{Km} \mathrm{NE}$ da cidade, 24-26.VI.1995, fr., A. Fuentes 1000 (MO); Chiquitos, 2Km W da Águas Calientes, 23.XI.1989, fl., M. Nee 37871 (MO, NY). PARAGUAI. AMAMBAY: Cerro Sarambi, 6.V.1989, fl., N. Soria 3719 (MO).

9. Mimosa dichroa Barneby ex G.P. Lewis. Legumes of Bahia: 133. 1987, emend. J. Santos-Silva \& A.M.G. Azevedo. Mimosa discolor Benth., J. Bot. (Hooker) 4: 391. 1842, nom. Illeg., non Andrew. Tipo: Goyaz, Gardner 3707 (Lectótipo: K (hb. Benth.)!, primeiro passo lectótipo designado por Barneby 1991:129= NY Neg. 1857!, segundo passo lectótipo designado aqui; Isolectótipos: BM!, K (hb. Hook.)! = NY Neg.11656!, W).

Fig. 2t-c'

Arbusto a arvoreta 1-4 $\mathrm{m}$ alt. Ramos inermes, puberulentos, castanhos. Tricomas simples acinzentados, entremeados por tricomas glandulares estipitados, distribuídos nos ramos, folhas e eixo da inflorescência. Estípulas 4-5 × $0,3-0,5 \mathrm{~mm}$, estreitamente triangulares a linear, não ciliada-glandulares. Folhas 6-9 pares de folíolos crescentes; pecíolo 2-3 cm compr.; raque 8,5-11,5 cm compr., interrompida entre cada par de folíolos por espícula caduca; segmento da raque 1,5-2 cm compr.; foliólulos 22-30 pares, decrescentes proximalmente; ráquila $6,5-10 \mathrm{~cm}$ compr., cilíndrica a subcilíndrica; lâmina 7-13 $\times$ 2-4 mm, cartácea, oblonga, base oblíqua a ligeiramente truncada, ápice agudo a ligeiramente 


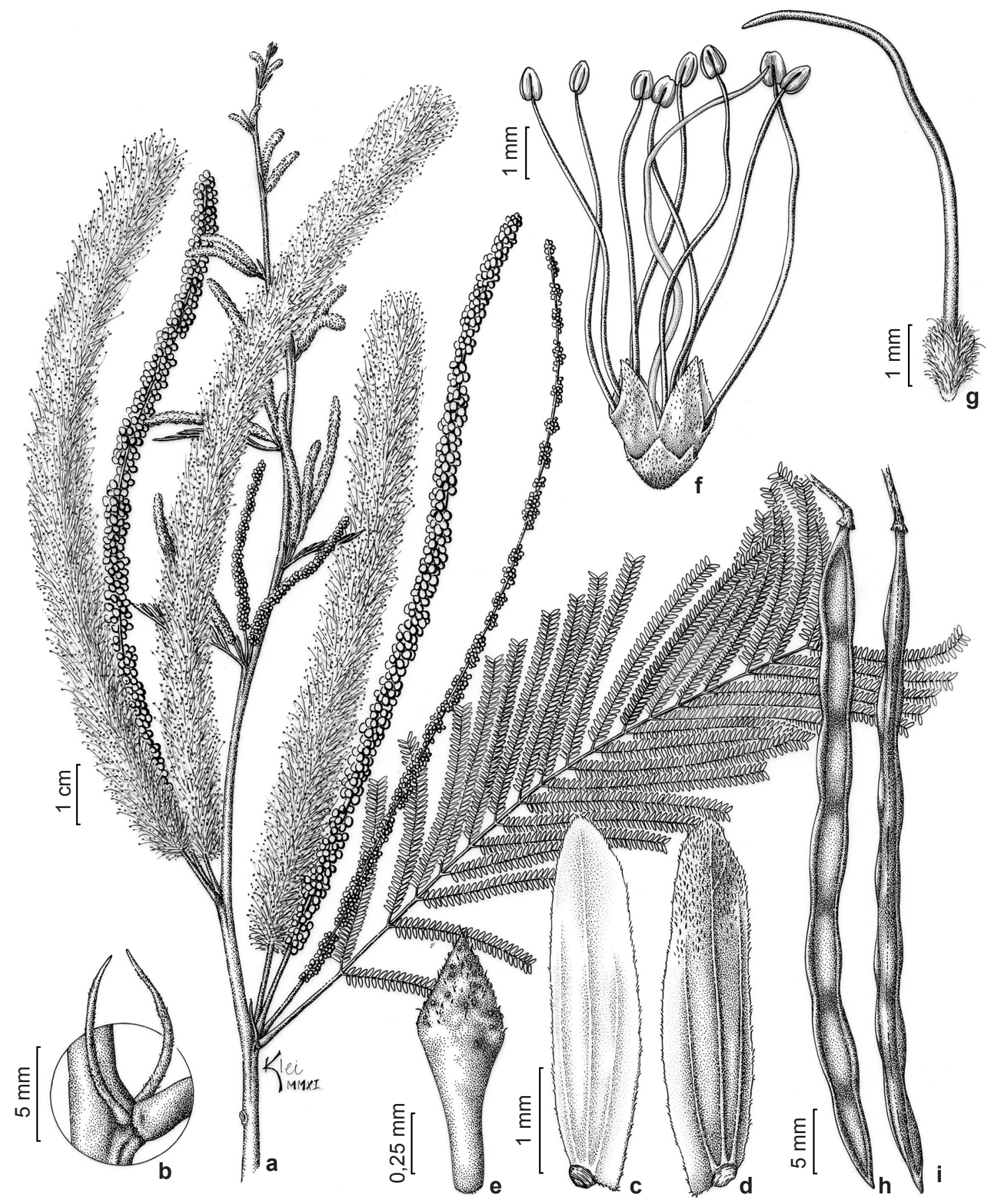

Figura 6 - Mimosa dalyi - a. ramo florido; b. detalhe das estípulas; c. foliólulo, face adaxial; d. foliólulo, face abaxial; e. bractéola; f. flor; g. gineceu; h. fruto; i. detalhe do fruto, vista lateral. (a-g. A.F. Fuentes 449; h-i. A.F. Fuentes 753). Figure 6 - Mimosa dalyi - a. flowering branch; b. detail of stipules; c. leaflet, adaxial surface; d. leaflet, abaxial surface; e. bract; f. flower; g. gynoecium; h. fruit; i. detail of fruit, side view. (a-g. A.F. Fuentes 449; h-i. A.F. Fuentes 753). 
arredondado, margem não revoluta, não ciliada ou ciliada, discolor, face adaxial verde-escuro, face abaxial verde-oliva, glabra a glabrescente, sem pontuações glandulares ou glândulas sésseis, 2-nervada, apenas a nervura central atingindo o ápice. Pedúnculo 1-3,5 cm compr.; brácteas 1-2, póximas ao ápice quando em botão. Espigas 2-6 $\times 0,4 \mathrm{~cm}$, congestas, solitárias a 2-5-fasciculadas, reunidas nos ramos desfolhados terminais; inflorescências latentes ausentes; bractéolas persistentes, menores que o botão floral, 0,9-1 $\times 0,3-0,4 \mathrm{~mm}$, obtruladas ou oblanceoladas, côncavas, não ciliada-glandulares. Flores tetrâmeras, bissexuadas, sésseis, pubescentes a vilosas; cálice 0,9-1 mm compr., cupuliforme, pubescente a viloso; corola 1,5-2 mm compr., campanulada, pubescente a vilosa, lacínias reflexas; filetes 5-7 mm compr., livres, róseos; ovário 0,8-1 mm compr., séssil, viloso; estilete 6-8 mm compr. Craspédios 4,5-7 × 0,4-0,6 $\mathrm{cm}$, cartáceos, 6-9-articulados, sésseis, lineares a oblongos, base atenuada, ápice mucronado, pubescentes, marrons; artículos quadrangulares, ligeiramente elevados na região das sementes; réplum $0,4-0,5 \mathrm{~mm}$, reto a ligeiramente constricto entre os artículos. Sementes não observadas.

Distribuição geográfica e habitat: espécie pontualmente distribuída nos estados da Bahia (Oeste), Goiás e Tocantins, em altitudes que variam de 290 a 700m. É encontrada preferencialmente em vegetação de cerrado (cerradão e campo sujo), sobre solos desde arenosos, argilosos a pedregosos. Algumas coletas desta espécie foram realizadas em vegetação de caatinga e em áreas de transições de mata de galeria e cerrado no estado de Goiás.

Fenologia: Flores foram observadas de janeiro a maio e frutos em junho e julho.

Mimosa dichroa pode ser facilmente distinta das demais espécies que apresentam filetes róseos por possuir ramos inermes, face abaxial dos folíolos sem glândulas, folhas com 6-9 pares de folíolos e espigas (2-5 por nó) dispostas em ramos desfolhados terminais. Além disso, possui corola pusbescente a vilosa com tricomas simples acinzentados, cuja coloração é perceptível até mesmo após a herborização.

A validade desta espécie e a sua relação com M. acutistipula foi trata como incerta por Barneby (1991). Para este autor, as diferenças observadas entre estes táxons eram frágeis quando analisadas isoladamente e era necessário avaliar os frutos de $M$. dichroa, não observados por ele, para uma conclusão da validade desta espécie e da sua relação com $M$. acutistipula. Após análise cuidadosa dos frutos e das demais estruturas, confirmamos neste trabalho a validade de $M$. dichroa e complementamos sua descrição original com as informações sobre os frutos.

Mimosa dichroa difere de M. acutistipula, principalmente, por apresentar folhas amplas com raque de 8,5 a $11,5 \mathrm{~cm}$ de comprimento ( $v s .1,5-6$ $\mathrm{cm}), 6$ a 9 pares de folíolos ( $v s .3-7$ pares), filetes róseos ( $v s$. brancos), frutos sésseis com valvas elevadas na região das sementes, puberulentos (vs. frutos compressos, estipitados, com estípite variando de 6 a $13 \mathrm{~mm}$, glabros).

Mimosa dichroa foi um nome dado por Barneby (1991) em substituição a Mimosa discolor, utilizado por Bentham (1842) para nomear esta espécie. Mimosa discolor sensu Benth. (1842) é um homônimo posterior, já empregado em outras duas espécies deste gênero, antes da publicação de Bentham (1842). O epíteto "discolor" foi utilizado pela primeira vez em 1802 por Andrew para designar uma espécie que atualmente pertence ao gênero Acacia (Acacia discolor (Andrew) Willd. = Acacia terminalis (Salisb.) J.F. Macbr.). Em 1810, Poiret usou novamente este epíteto específico ao combinar Inga discolor Humb. \& Bonpl. ex Willd. em Mimosa (= Macrosamanea discolor (Humb. \& Bonpl. ex Willd.) Britton \& Rose ex Britton \& Killip.). Lewis (1987), ao listar as espécies de Mimosa ocorrentes na Bahia, empregou pela primeira vez o nome "dichroa" atribuindo-o a Barneby (Mimosa dichroa Barneby inéd., Lewis 1987). Apesar deste autor ter reconhecido Barneby como criador do nome, o trabalho onde foi estabelecida esta mudança foi o livro Legumes of Bahia e não a monografia de Barneby (1991) como vem sendo amplamente citado.

Barneby (1991) mencionou a coleta de Gardner 3707 como holótipo. No entanto, o número de coleta de Gardner informado no protólogo (J. Bot. (Hooker) 4: 391. 1842) é 3787 e não 3707 como citado por este autor. Entretanto, como não foi encontrado o material de Gardner 3787 nos herbários visitados, interpretamos a escolha de Barneby como o primeiro passo de uma lectotipificação inferencial e o segundo passo é aqui designado.

O epíteto específico "dichroa" (duas cores) provavelmente foi utilizado em alusão aos seus folíolos discolores. 
Material selecionado: BRASIL. BAHIA: Espigão Mestre, 3.III.1972, fl., W.R. Anderson, M. Stleber \& J.H. Kirkbridge 36554 (NY, UB). GOIÁS: Alto Paraíso, depois do Rio Paranoá, $117 \mathrm{Km}$ de Alto Paraíso, Km 283, entre Teresina de Goiás e Campos Belos, 8.V.2012, fl., J.S. Silva et al. 1104 (CEN, HUNEB, UEC); Teresina de Goiás, $54.7 \mathrm{Km}$ de Alto do Paraíso, entrada cachoeira do Poço encantado, 8.V.2012, fl., J.S. Silva \& H. Moreira 1098 (CEN, HUNEB, UEC). TOCANTINS: Arraias, rodovia TO-50, km 415,10.V.2000, fl., G. Hatschbach et al. 70870 (MBM).

10. Mimosa fiebrigii Hassl., Repert. Spec. Nov. Regni Veg. 9: 9.1910. Tipo: Paraguai, Zwischen Rio Apa und Rio Aquidaban, trockener Berg Campo 1908/1909, K. Fiebrig 4476 (Lectótipo: G!, designado por Barneby [1991: 153], F Neg. 28208!; Isolectótipos: BM!, E, K!, L, M!, P, SI!, Z).

Fig. 7

Arvoreta 1,5-4 m alt.. Ramos inermes, puberulentos, castanhos. Tricomas simples esbranquiçados entremeados por glândulas sésseis, arredondadas, douradas, distribuídos nos ramos, folhas, face abaxial dos foliólulos, pedúnculo, bractéolas, cálice e ápice da corola. Estípulas $1,5-3 \times 0,2 \mathrm{~mm}$, estreitamente triangulares, não ciliada-glandulares. Folhas 7-16 pares de folíolos crescentes; pecíolo 0,5-1 cm compr.; raque $3,5-6,5 \mathrm{~cm}$ compr., interrompida entre cada par de foíolos por espícula; segmento da raque $0,2-0,4$ cm compr.; foliólulos 23-34 pares, decrescentes proximalmente; ráquila $3-3,5 \mathrm{~cm}$ compr., sulcada; lâmina 2,5-3 ×0,5 mm, cartácea, oblonga, base oblíqua a ligeiramente truncada, ápice agudo, margem não revoluta, ciliada, discolor, face adaxial verde-escuro, face abaxial verde-oliva, glabra a glabrescente, 1-nervada, nervura central atingindo $\mathrm{o}$ ápice. Pedúnculo 1-3,5 $\mathrm{cm}$ compr.; brácteas $1-2$, póximas ao ápice. Espigas 1-1,5 × 0,4 $\mathrm{cm}$, congestas, solitárias a 2 -fasciculadas, nas axilas de folhas jovens ou totalmente desenvolvidas; inflorescências latentes ausentes; bractéolas persistentes, menores que o botão floral, 1-1,2 $\times$ $0,2 \mathrm{~mm}$, estreitamente lanceoladas, não ciliadaglandulares. Flores tetrâmeras, bissexuadas ou unissexuadas, sésseis; cálice $0,4-0,6 \mathrm{~mm}$ compr., cupuliforme, ciliado, glabro com glândulas; corola 2-3 mm compr., campanulada a tubular, às vezes, quadrangular, pilosas, geralmente com tricomas mais adensados no ápice, lacínias eretas; filetes 7-8 mm compr., curtamente unidos na base, róseos; ovário $0,9-1 \mathrm{~mm}$ compr., curtamente estipitado (ca. $0,4 \mathrm{~mm}$ compr.), tomentoso; estilete $8-9 \mathrm{~mm}$ compr.. Craspédios 2,5-5,5 × 0,5-0,6 cm, cartáceos, 4-10-articulados, curtamente estipitados, estípite 2-3 mm compr., oblongos, base arredondada, ápice agudo a mucronado, tomentosos, marrons; artículos quadrangulares ou retangulares, elevados na região das sementes; réplum ligeiramente a fortemente constricto entre os artículos, $0,3-0,4 \mathrm{~mm}$. Sementes $5 \times 4 \mathrm{~mm}$, elipsoides, marrons.

Distribuição geográfica e habitat: Mimosa fiebrigii foi citada por Barneby (1991) apenas para o Paraguai, mas encontramos uma população desta espécie crescendo também no município de Porto Murtinho (MS), tratando-se portanto, de uma nova ocorrência. No Brasil é encontrada em áreas de chaco e cerrado. No Paraguai ocorre nos departamentos de Alto Paraguai, Amambay e Concepción em áreas de cerrados e de transição cerrado-chaco sobre solos arenosos e pedregosos.

Fenologia: flores foram observadas em março, abril e outubro e frutos em março.

Mimosa fiebrigii é a única espécie da Mimosa ser. Leiocarpae s.l. que apresenta 1-2 brácteas próximas ao ápice do pedúnculo e inflorescências curtas $(1-1,5 \mathrm{~cm})$, cuja proporção comprimento inflorescência/pedúnculo geralmente não ultrapassa $2: 1$. Nas demais espécies, as inflorescências variam de 1,5 a $18 \mathrm{~cm}$ com proporção maior que $2: 1$ e as brácteas são encontradas predominantemente na base do pedúnculo.

Barneby (1991) classificou as inflorescências de $M$. fiebrigii como glomérulos elipsoides, provavelmente por considerar que as suas flores estão adensadas no receptáculo e não inseridas esparçadamente ao longo do receptáculo como é observado nas espigas curtas. No entanto, ao analisar mais material observamos que estas são espigas predominantemente cilíndricas ou elipsoides que exibem um eixo mais curto do que observado nas demais espécies de Mimosa ser. Leiocarpae s.l.

Mimosa fiebrigii foi descrita com base em três síntipos (Rojas s.n, Fiebrig 4476 e 4239) todos do Paraguai e sem data de coleta. Barneby (1991) elegeu a coleta de Fiebrig 4476 como lectótipo, transcrevendo as mesmas informações da localidade de coleta citada no protólogo (Paraguay: In glareosis pr. Yevicá, trockener Berg Campo, flor. et fruct., mens. Mart.) e incluindo o ano de 1909 às informações da coleta. $\mathrm{O}$ epíteto espécifico foi dado em homenagem ao botânico Karl Fiebrig, um dos primeiros coletores desta espécie.

Material selecionado: BRASIL. MATO GROSSO DO SUL: Porto Murtinho, 10.III.2011, fl. e fr., J.S. Silva \& G.H. Shimizu 912 (UEC); idem, 10 III 2011, fl. e fr., 
J.S. Silva \& G.H. Shimizu 913 (UEC). PARAGUAI. AMAMBAY: de Bella Vista ad Estancia S. Luis, 16-17.IV.1980, fl., L. Bernandi 20620 (MO, NY). CONCEPCIÓN: s. loc., 16.I.2000, fl., E.M. Zardini \& L. Guerrero (MO 53959).

11. Mimosa gemmulata Barneby, Brittonia 37 : 130. 1985. Tipo: Brasil, Minas Gerais, circa Farada, i.e., Vila Fanado [Minas Novas], near $16^{\circ} 35^{\prime}$ S, $42^{\circ} 45^{\prime} \mathrm{W}$, anno 1820, J.E. Pohl 1392=3407 (Holótipo: NY!; Isótipos: $\mathrm{B}=\mathrm{F}$ Neg. 1361!, F! = F Neg 54846!, K!, US!, W).

Mimosa gemmulata var. adamantina Barneby, Brittonia 37: 132, fig. 3j-1. 1985. Tipo: Brazil, Bahia: Sa. do Acuruá, Blanchet 2850 (Holótipo: G; Isótipos: BM; F Neg. 63140!, K!, NY!), syn. nov. Mimosa pteridifolia Benth. var. nanophylla Rizz., Rodriguésia 32 (55): 17.1980. Tipo: Brasil, Minas Gerais, Pedra Azul, Colônia Grande, mais de $1 \mathrm{~km}$ de extensão no Agreste entre Itaobim, 11 Nov 1958, M. Magalhães 15017 (Lectótipo: RB! aqui designado).

Mimosa gemmulata var. cristalina Barneby, Mem. New York Bot. Gard. 65: 151.1991. Tipo: Brasil, Goiás, Sa. dos Cristais, ca. 10 km w. of Cristalina, 4 Mar 1966, H.S. Irwin et al. 13437 (Holótipo: UB!; Isótipos: C, G, K!, LE, NY!, P, R!, S, US!), syn. nov. Mimosa gemmulata var. segrex Barneby, Mem. New York Bot. Gard. 65: 150-151.1991. Tipo: Venezuela, Lara, entre Paso Real y Quibor, Distrito Menez, 1000 m, 9 52' N Lat., 69³7' O Long., 7 July 1974, J.A. Steyermark 110258 (Holótipo: F! = NY Neg 11897!, Isótipo: VEN), syn. nov.

Fig. $5 q-x$

Arvoreta a subarbusto 1-4 m alt.. Ramos inermes, puberulentos, tomentosos a vilosos, marrom-escuros. Tricomas simples amarelados, entremeados por glândulas sésseis, lentiformes, douradas, translúcidas a alaranjadas distribuídos nos ramos, estípulas, folhas, face abaxial dos foliólulos, pedúnculo, bractéolas, cálice, ápice da corola e frutos. Estípulas 0,5-10 × 0,2-0,8 $\mathrm{mm}$, estreitamente triangulares a ovais, não ciliada-glandulares. Folhas 9-21 pares de folíolos crescentes; pecíolo 0,4-1,5 cm compr.; raque 4-10,5 cm compr., interrompida entre cada par de folíolos ou apenas nos distais por espícula; segmento da raque $0,2-0,7 \mathrm{~cm}$ compr.; foliólulos 18-43 pares, decrescentes proximalmente; ráquila 1,5-6 cm compr., sulcada a cilíndrica; lâmina 1,2-2 $\times 0,5-2 \mathrm{~mm}$, cartácea a cartácea-coriácea, oblonga, base oblíqua, ápice arredondado, margem não revoluta, ciliada a não ciliada, discolor, face adaxial verde-escuro, glabra a puberulenta, face abaxial verde-oliva, glabrescente, 1-nervada, nervura central atingindo o ápice. Pedúnculo $0,5-2,5 \mathrm{~cm}$ compr.; brácteas ausentes. Espigas 3,5-13 × 0,3$0,4 \mathrm{~cm}$, laxifloras, solitárias a $2-3$-fasciculadas, nas axilas de folhas jovens ou totalmente desenvolvidas ou, menos frequentemente, em ramos desfolhados; inflorescências latentes ausentes; bractéolas persistentes, menores que o botão floral, $0,3-1 \times$ 0,2-0,3 mm, oblanceoladas, ligeiramente côncavas, não ciliada-glandulares. Flores tetrâmeras, bissexuadas, sésseis; cálice 0,4-1 mm compr., cupuliforme, glabrescente a pubescente; corola 1,5-2,3 mm compr., campanulada, glabrescente a pubescente, lacínias eretas ou reflexas; filetes 6-8 mm compr., livres, róseos; ovário 0,9-1 $\mathrm{mm}$ compr., curtamente estipitado (ca. 0,3 mm compr.), pubescente a viloso; estilete 5-7 mm compr.. Craspédios 1,7-3 × 0,4-0,6 cm, cartáceos, 3-7-articulados, sésseis a curtamente estipitados, estípite 2-3 mm compr., estreitamente oblongos, base atenuada a arredondada, ápice agudo, mucronado a cuspidado, glabrescentes, castanhos; artículos quadrangulares ou menos frequente elipsoides, compressos ou elevados na região da semente; réplum reto a ligeiramente constricto entre os artículos, 0,4-0,9 mm. Sementes 3-4 × 2-2,5 $\mathrm{mm}$, ovoides a elipsoides, marrons.

Distribuição geográfica e habitat: Mimosa gemmulata ocorre no Brasil e no norte da Venezuela. No Brasil é encontrada na Bahia, Minas Gerais, Goiás, Pernambuco e Piauí, crescendo em vegetação de caatinga, cerrado, campo rupestre ou em áreas de pastos e beira de estradas, em altitudes que variam 320 a $1200 \mathrm{~m}$. Na Venezuela foi coletada apenas no estado de Lara, em áreas de chaparral, onde está frequentemente associada a montanhas rochosas, cuja altitude pode alcançar até $1000 \mathrm{~m}$.

Nome popular: jurema

Mimosa gemmulata pode ser reconhecida pelo ramos inermes, folhas com 9 a 21 pares de folíolos e 18 a 43 foliólulos, glândulas sobre o cálice, corola e frutos, bem como pelas espigas desenvolvendo-se nas axilas de folhas jovens ou, menos frequentemente, em ramos desfolhados. Além disso, os filetes róseos e o ovário pubescente a viloso também podem auxiliar no seu reconhecimento.

Pode ser confundida com M. amnis-atri, no entanto, esta espécie possui um maior número de folíolos (28-49 pares vs. 9-21 pares em $M$. 


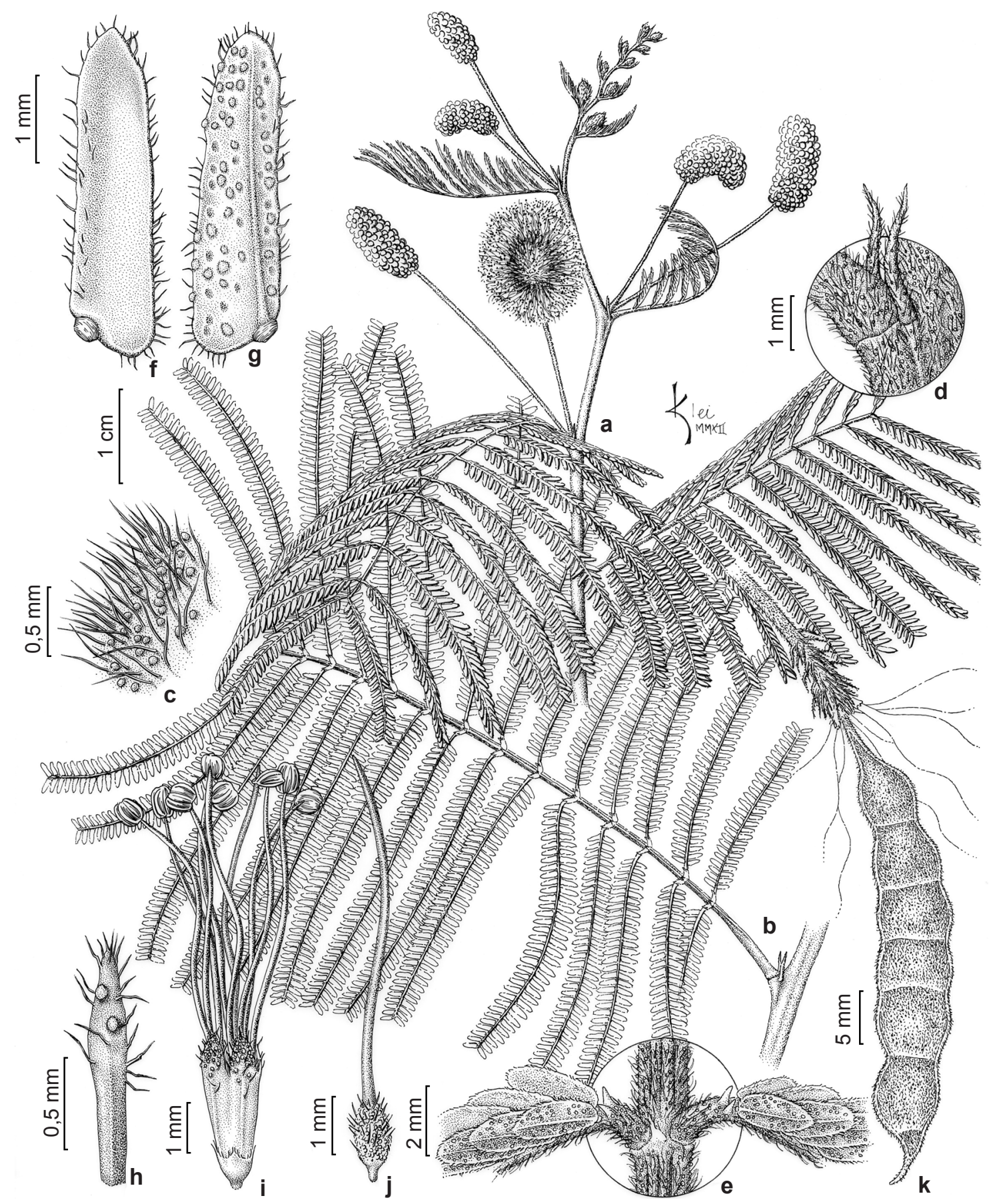

Figura 7 - Mimosa fiebrigii - a. ramo florido; b. folha; c. detalhe do indumento dos ramos; d. detalhe das estípulas; e. detalhe da raque mostrando a espícula e os parafilídios; f. foliólulo, face adaxial; g. foliólulo, face abaxial; h. bractéola; i. flor; j. gineceu; k. fruto. (J.S. Silva \& G.H. Shimizu 912).

Figure 7 - Mimosa fiebrigii - a. flowering branch; b. leaf; c. detail of branch indumentum; d. detail of stipules; e. detail of leaf rachis, showing spicule and paraphyllidia; f. leaflet, adaxial surface; g. leaflet, abaxial surface; h. bract; i. flower; j. gynoecium; k. fruit. (J.S. Silva \& G.H. Shimizu 912). 
gemmulata), sendo todos do mesmo tamanho (vs. geralmente crescentes) e frutos lineares (vs. estreitamente oblongos). Além disso, os seus ramos apresentam folhas densamente distribuídas em toda sua extensão ( $v s$. em geral adensadas no ápice dos ramos) e as suas inflorescências desenvolvemse, em geral, em ramos desfolhados bem acima das folhas ( $v s$. frequentemente nas axilas de folhas jovens ou totalmente desenvolvidas).

A esta espécie, Barneby (1991) subordinou cinco variedades baseado em características relacionadas às folhas e aos frutos como, por exemplo, número de folíolos e de foliólulos, forma e tamanho da lâmina e número de artículos. Nesta classificação, este autor utilizou também dados referentes à distribuição das populações. As análises dos indivíduos em campo e dos espécimes examinados demonstraram que, realmente, existe uma variação no número de pares de folíolos e foliólulos, tamanho da raque e ráquila e, atrelado a isto, uma variação no padrão dos foliólulos (crescente, decrescente ou de tamanho igual). Entretanto, observamos que esta variação é contínua e que vários indivíduos apresentam caracteres intermediários entre as variedades. Dessa forma, as diferenças observadas são entendidas aqui como uma variação inerente a esta espécie e, assim sendo, propõe-se a sinonimização de $M$. gemmulata var. adamantina Barneby, $M$. gemmulata var. segrex Barneby, M. gemmulata var. cristalina em M. gemmulata.

Mimosa pteridifolia var. nanophylla foi descrita por Rizzini (1980), com base em três síntipos, todos procedentes de Minas Gerais: Pedra Azul-Itaobim, G.M. Magalhães 15017 (RB); A. de Saint-Hilaire (P, RB) e Montes Claros, F. Markgraf, M. Barreto \& A.C. Brade (RB). Posteriormente, Barneby (1991) incluiu este táxon na circunscrição de $M$. gemmulata, entretanto considerou este nome tecnicamente inválido justificando que Rizzini (1980) não nomeou o holótipo. Apesar de concordamos com este autor a respeito da sinonimização de $M$. pteridifolia var. nanophylla em $M$. gemmulata, desconsideramos sua opinião sobre a validade deste nome. Assim, no presente trabalho elege-se como lectótipo de M. pteridifolia var. nanophylla o espécime Pedra Azul-Itaobim, G.M. Magalhães 15017, depositado no RB.

O epíteto "gemmulata" refere-se a semelhança das glândulas que revestem as suas estruturas vegetativas e reprodutivas com a gema do ovo.
Material selecionado: BRASIL. BAHIA: Caetité, Serra Geral de Caetité, Ca. 5Km S. para Caetité, 9.IV.1980, fl., R.M. Harley 21116 (K, RB, US). GOIÁS: Cana Brava, 13.VI.1990, fl., R.R. Broks, R.D. Reeves \& H.D. Fereira 458 (K). MINAS GERAIS: Bocaiúva, BR 367, Km 20, 23.X.1999, fl., G. Hatschbach et al. 69557 (K, MBM). PERNAMBUCO: Buíque, Serra do Catimbau, 8.V.1995, fl., A.P.S. Gomes \& A. Laurênio 304 (K, PEUFR). VENEZUELA: Humocaro, 25.IX.1922, fl., A. Jahn 1193 (NY, US).

12. Mimosa glutinosa Malme, Ark. Bot. 23A: 51, fig. 8 c. 1931 . Tipo: [Brasil, Mato Grosso do Sul], Porto Murtinho, [25 July 1903], Malme 2785a (Lectótipo: S!; designado por Barneby [1991:140]).

Mimosa millefoliata var. glaberrima Chodat \& Hassl., Bull. Herb. Biossier II, 4: 554. 1904. Tipo: "...in campis siccis region is superior is fluminis Apa, Dec.” [Hassler] n. 8299 (Holótipo: G; Isótipos: BM!, C, F!, G, GH, K, NY!, P, S!, US!, W).

Fig. 8

Árvore 4-7 m alt.. Ramos aculeados, às vezes, inermes, puberulentos a glabros, quando jovens acinzentados. Acúleos infranodais, distribuídos aos pares, discretamente recurvados. Tricomas simples esbranquiçados, entremeados por glândulas sésseis, lentiformes, amareladas distribuídos nos ramos, folhas, face abaxial dos foliólulos, eixo da inflorescências, flores e frutos. Estípulas 1,8-2 $\times$ 0,6-0,7 mm, triangulares, não ciliada-glandulares. Folhas 12-19 pares de folíolos crescentes; pecíolo 0,7-2 cm compr.; raque (5,5-)8,5-14 cm compr., interrompida entre cada par de folíolos por espícula; segmento da raque $0,4-0,8 \mathrm{~cm}$ compr.; foliólulos (20-)22-40 pares, decrescentes proximalmente; ráquila (3-)4,5-5,5 cm compr., caniculada; lâmina 3-4,7 ×0,7-1 mm, cartácea, oblonga, base oblíqua, ápice discretamente agudo, margem não revoluta, discretamente ciliada, discolor, face adaxial verdeescuro, glabra, opaca, face abaxial verde-oliva, raramente resinosa, 1-nervada. Pedúnculo 2-4 mm compr.; brácteas ausentes. Espigas 3-10 $\times$ 0,2-0,4 cm, laxifloras, solitárias, nas axilas de folhas jovens ou totalmente desenvolvidas, ou menos frequentemente em ramos desfolhados; inflorescências latentes ausentes; bractéolas persistentes, menores que o botão floral, 0,3-0,5 $\times 0,2-0,3 \mathrm{~mm}$, oblongas, obtruladas a ovais, não ciliada-glandulares. Flores tetrâmeras e pentâmeras na mesma inflorescência, bissexuadas, sésseis; cálice $0,3-0,5 \mathrm{~mm}$ compr., cupuliforme, resinoso, glabro a raramente ciliado; corola 2,3-3 $\mathrm{mm}$ compr., campanulada, resinosa, glabra, lacínias 
eretas; filetes 5-9 mm compr., livres, brancos; ovário $0,7-0,8 \mathrm{~mm}$ compr., séssil, seríceo; estilete 5,5-7 mm compr.. Craspédios 6-11 × 0,7-1,1 cm, sublenhosos, 6-11-articulados, sésseis, lineares a oblongos, base atenuada, ápice agudo, acuminado a cuspidado, glabros, marrom-escuros; artículos quadrangulares, lustrosos, resinosos, elevados na região das sementes; réplum discretamente constricto entre os artículos, ca. $0,5 \mathrm{~mm}$. Sementes 4-5 × 4-5 mm, ovoides a orbiculares, marromclaras.

Distribuição geográfica e habitat: Mimosa glutinosa foi observada ao longo do rio Paraguai e seus afluentes no estado de Goiás e Mato Grosso do Sul, no Brasil, e no norte do Paraguai, crescendo em cerrado, carrasco, mata ciliar e chaco, sobre solo areno-argiloso. No Mato Grosso do Sul foi coletada em regiões com cotas altitudinais variando de $80 \mathrm{a}$ $100 \mathrm{~m}$ de altitude. Alguns indivíduos verificados no Parque Hermógenes de Freitas Leitão Filho no município de Campinas (SP), provavelmente, foram introduzidos nesta localidade.

Fenologia: coletada com flores em janeiro, fevereiro, março e dezembro e, com frutos janeiro, março, abril, agosto e outubro.

Nome popular: angiquinho

Esta espécie pode ser reconhecida pelos ramos acinzentados, aculeados, cujos acúleos distribuem-se aos pares, folhas 12-19 pares de folíolos, flores brancas e frutos sublenhosos com artículos elevados na região das sementes.

Mimosa glutinosa é facilmente confundida com $M$. interrupta, devido à presença de um par de acúleos sempre abaixo dos nós, às inflorescências laxifloras, à corola e ao cálice resinosos pelo adensamento de glândulas, aos filetes brancos e aos frutos sublenhosos, resinosos. Mimosa interrupta possui foliólulos maiores, 6-10 × 1,2-3 mm (vs. 3-4,7 × 0,7-1 mm em $M$. glutinosa) de consistência cartáceo-coriáceo, com a face adaxial lustrosa e a abaxial resinosa, bem como um maior número de nervuras, 2-4 (vs. uma nervura) e craspédios compressos (vs. artículos elevados na região das sementes). Além disso, estas espécies apresentam distribuição geográfica distinta, M. glutinosa ocorre espontaneamente em Goiás, Mato Grosso do Sul estendendo-se até o norte do Paraguai, enquanto $M$. interrupta é verificada em Goiás, Maranhão e Mato Grosso.

Do latim, glutinosa $($ gluten $=$ grude ou cola $)$ foi utilizado para descrever as folhas ou flores pegajosas ao tato.
Material selecionado: BRASIL. GOIÁS: Jussara, 4,5 Km de cidade, 24.III.2004, fl., A. Pott 14142 (UEC). MATO GROSSO DO SUL: Bela Vista, Rod. BA 060, Km N, 2.II.1998, fl., O.S. Ribas \& L.B.S. Pereira 2420 (MBM, NY). SÃO PAULO: Campinas, 20.III.2010, fr., J.S. Silva et al. 852 (UEC). PARAGUAI. ALTO PARAGUAY: 29.III.1980, fr., Bernardi 20407 (MO, NY). AMAMBAY: Bella Vista, 25.V.1983, fr., W. Hahn et al. 1335 (MO, NY).

13. Mimosa hapaloclada Malme, Bih. Kongl. Svenska Vetensk. - Akad. Handl. 25, Afd. 3 (11): 40. 1900. Tipo: Matto Grosso, Cuyabá, In cerrado denso, 3 Jan 1894, Malme 1308 (Holótipo: S!; Isótipos: BM!, F!, SI!, G, US!). $\quad$ Fig. 9

Arbusto 1,5-3 m alt.. Ramos aculeados, puberulentos a tomentosos, castanhos a acinzentados. Acúleos internodais, retos a ligeiramente recurvados. Tricomas simples esbranquiçados raramente, entremeados por tricomas glandulares, curto-estipitados ou sésseis distribuídos nos ramos. Estípulas 5-6 × 0,2-0,3 $\mathrm{mm}$, lineares, não ciliada-glandulares. Folhas 13-25 pares de folíolos crescentes; pecíolo 0,5-1 cm compr.; raque 7,5-9 cm compr., interrompida entre cada par de folíolos por espícula; segmento da raque $0,4-0,7 \mathrm{~cm}$ compr.; foliólulos 31-36 pares, decrescentes proximalmente; ráquila $1,8-3$ cm compr., caniculada; lâmina 2-4 × 0,5-0,6 $\mathrm{mm}$, membranácea, oblonga, base oblíqua a discretamente truncada, ápice agudo, margem não revoluta, espasadamente ciliada, discolor, face adaxial verde-escuro, face abaxial verde-oliva, sem pontuações glandulares ou glândulas sésseis, glabra, 1-nervada. Pedúnculo 5-8 mm compr.; bráctea 1, póxima ao ápice. Espigas 3-4 ×0,4 cm, congestas, solitárias a 2-3-fasciculadas, nas axilas de folhas jovens ou totalmente desenvolvidas; inflorescências latentes ausentes; bractéolas persistentes, menores que o botão floral, 0,9-1 $\times 0,2-0,3 \mathrm{~mm}$, oblanceoladas, não ciliadaglandulares. Flores tetrâmeras, bissexuadas, sésseis; cálice 0,4-0,5 mm compr., cupuliforme, tomentoso; corola 2-3 mm compr., campanulada, tomentosa a velutina, lacínias eretas; filetes 6-7 $\mathrm{mm}$ compr., livres, róseos; ovário 0,9-1 mm compr., estipitado, estípite ca. $1 \mathrm{~mm}$, viloso a lanuginoso; estilete 5-6 mm compr.. Craspédios 4,5-5 × 0,4-0,5 cm, cartáceos, 5-6-articulados, sésseis, lineares, base atenuada formando um curtoestípite 2-3 mm, ápice acuminado, glabrescentepuberulentos, marrons; artículos discretamente elevados na região das sementes; réplum constricto 


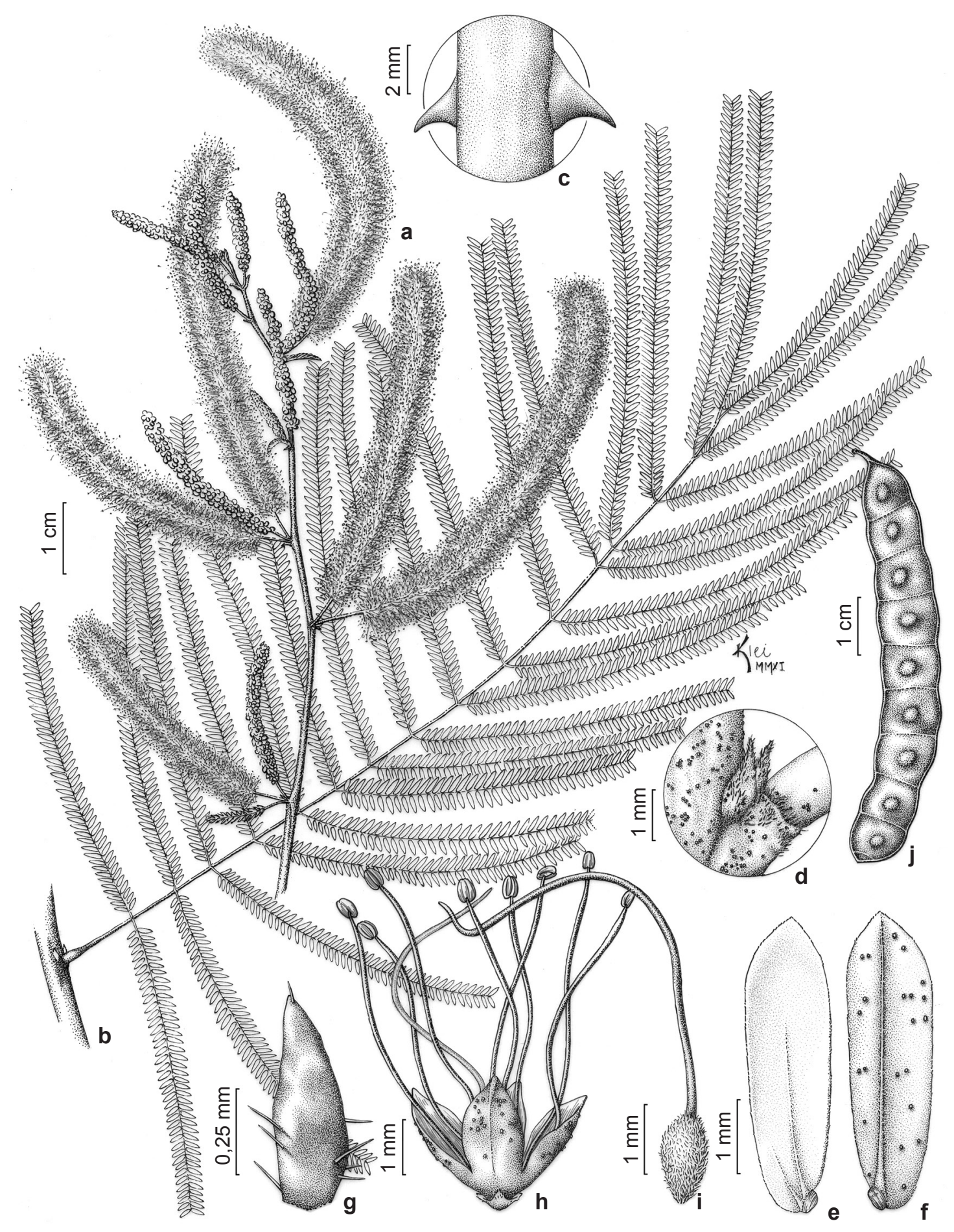

Figura 8-Mimosa glutinosa - a. ramo florido; b. folha; c. detalhe dos acúleos; d. detalhe das estípulas; e. foliólulo, face adaxial; f. foliólulo, face abaxial; g. bractéola; h. flor; i. gineceu; j. fruto. (J.S. Silva et al. 852).

Figure 8-Mimosa glutinosa - a. flowering branch; b. leaf; c. detail of aculei; d. detail of stipules; e. leaflet, adaxial surface; f. leaflet, abaxial surface; g. bract; h. flower; i. gynoecium; j. fruit. (J.S. Silva et al. 852). 
entre os artículos, 0,4-0,5 mm. Sementes imaturas 1,3-1,5 × 0,8-0,9 mm, ovoides, verdes.

Distribuição geográfica e habitat: espécie encontrada em vegetação de cerrado s.s., campo sujo ou em áreas antropizadas dos estados de Goiás, Mato Grosso, Mato Grosso do Sul e Tocantins, geralmente associada a solos arenosos. É observada em altitudes que variam de 200 a $700 \mathrm{~m}$. Uma viagem foi realizada no período de floração para município de Três Lagoas (MS) para coletar M. hapaloclada, mas infelizmente a vegetação da localidade de coleta (Fazenda Matão) foi praticamente toda substituída por uma plantação de Eucalyptus spp. e não encontramos nenhum indivíduo desta espécie portanto, supomos que ela esteja localmente extinta. Em Arraias (TO) encontramos um único indivíduo crescendo na beira da estrada, próximo do Campus da UFT.

Fenologia: Floresce em fevereiro, março e setembro.

Mimosa hapaloclada é caracterizada pelo hábito arbustivo, ramos aculeados com acúleos diminutos, folhas com 13-25 pares de folíolos, ausência de glândulas nos foliólulos, corola tomentosa a velutina, filetes róseos e frutos estipitados.

Apesar de alopátricas, M. hapaloclada apresenta maiores similaridades morfológicas com M. arenosa, mas difere desta por apresentar acúleos retos (frequentemente recurvados em $M$. arenosa), folhas com um maior número de folíolos (13-25 vs. 5-12), corola tomentosa a velutina (vs. comumente glabra) e filetes róseos ( $v s$. brancos).

Malme (1900) quando descreveu $M$. hapaloclada considerou M. apodocarpa como a espécie mais afim. No entanto, as espécies são bastante distintas morfologicamente: em $M$. hapaloclada, a face abaxial dos foliólulos não possui glândulas, os filetes são róseos e os frutos estipitados; $M$. apodocarpa, possui a face adaxial dos foliólulos revestida por tricomas glândulares sésseis, os filetes são brancos e os frutos sésseis.

Do Grego hapalo, que significa macio, e clada, que significa ramo, devido ao indumento dos ramos.

Material selecionado: BRASIL. GOIÁS: Campos Belos, Rio Bezerra, 15.II.1990, fl., G. Hatschbach et al. 54003 (K, MBM, MO, US). MATO GROSSO: Cuiabá, 3.I.1894, fl., Gust A. \& N. Malme (RB 3336). MATO GROSSO DO SUL: Três Lagoas, 4.IX.1984, fl., F.R. Martins 16250 (UEC). TOCANTINS: Arraiais, próximo ao Campus da UFT, 12.V.2012, fr., J.S. Silva et al. 1175 (CEN, UEC, HUNEB).
14. Mimosa hebecarpa Benth., J. Bot. (Hooker) 5: 87.1846. Tipo: Brasil, Rio Pardo, Riedel s.n. (Holótipo: Riedel 430, K-000504856 (Heb. Benth.)!; Isótipo: LE).

Fig. 10

Arbusto a arvoreta 1-7 m alt.. Ramos inermes, puberulentos a tomentosos, castanhos, quando jovens ferrugíneos. Tricomas simples esbranquiçados a ferrugíneos, entremeados por glândulas sésseis, lentiformes ou globosas, amarelo-translúcidas a acobreadas distribuídos nos ramos, folhas, face abaxial dos foliólulos, corola, ovário e frutos. Estípulas $2-3 \times 0,3-0,4$ $\mathrm{mm}$, estreitamente triangulares, não ciliadaglandulares. Folhas 10-21 pares de folíolos crescentes; pecíolo 1-3 cm compr.; raque (8-)11$16 \mathrm{~cm}$ compr.; espículas ausentes; segmento da raque 0,4-1 cm compr.; foliólulos 28-47 pares, ligeiramente crescentes; ráquila 4,5-8 cm compr., canaliculada a cilíndrica; lâmina 3,5-6,5 × 0,8-1,8 $\mathrm{mm}$, cartácea, oblonga a ligeiramente oval, base oblíqua, ápice arredondado, margem não revoluta, ciliada a não ciliada, discolor, face adaxial verdeescura, opaca, glabra a pubescente, face abaxial verde-oliva, glabra, 1-nervada. Pedúnculo 4-8 mm compr.; brácteas ausentes. Espigas 6,5-18 $\times$ 0,3-0,5 cm, congestas, solitárias a 2-fasciculadas, desenvolvendo-se em ramos velhos desfolhados abaixo das folhas; inflorescências latentes ausentes; bractéolas persistentes, ligeiramente maiores ou iguais ao botão floral, $1-2 \times 0,2-0,5 \mathrm{~mm}$, lineares, oblanceoladas, truladas a obtruladas, côncavas, não ciliada-glandulares. Flores tetrâmeras, bissexuadas, sésseis; cálice 0,6-1,5 mm, cupuliforme, glabro a tomentoso; corola 2-3 mm compr., campanulada, tomentosa a vilosa, geralmente com tricomas mais adensados no ápice, lacínias eretas; filetes 6-8 mm compr., livres, róseos; ovário 0,6-1 $\mathrm{mm}$ compr., curtamente estipitado $(0,3 \mathrm{~mm}$ compr.), seríceo em toda sua extensão ou apenas no ápice; estilete 9-10 mm compr.. Craspédios 2,3-3,5 × 0,5-0,8 cm, cartáceos, 5-7-articulados, sésseis, oblongos a elípticos, base atenuada, ápice cuspidado, tomentoso-vilosos, marrons; artículos quadrangulares a retangulares, elevados na região das sementes; réplum ligeiramente constricto entre os artículos, 0,3-0,4 mm. Sementes 3-4×3-4 mm, orbiculares, marrom-claras.

Distribuição geográfica e habitat: Mimosa hebecarpa distribui-se nos estados de Goiás, Mato Grosso e Mato Grosso do Sul. Alguns indivíduos cultivados no Instituto Agronômico de Campinas 


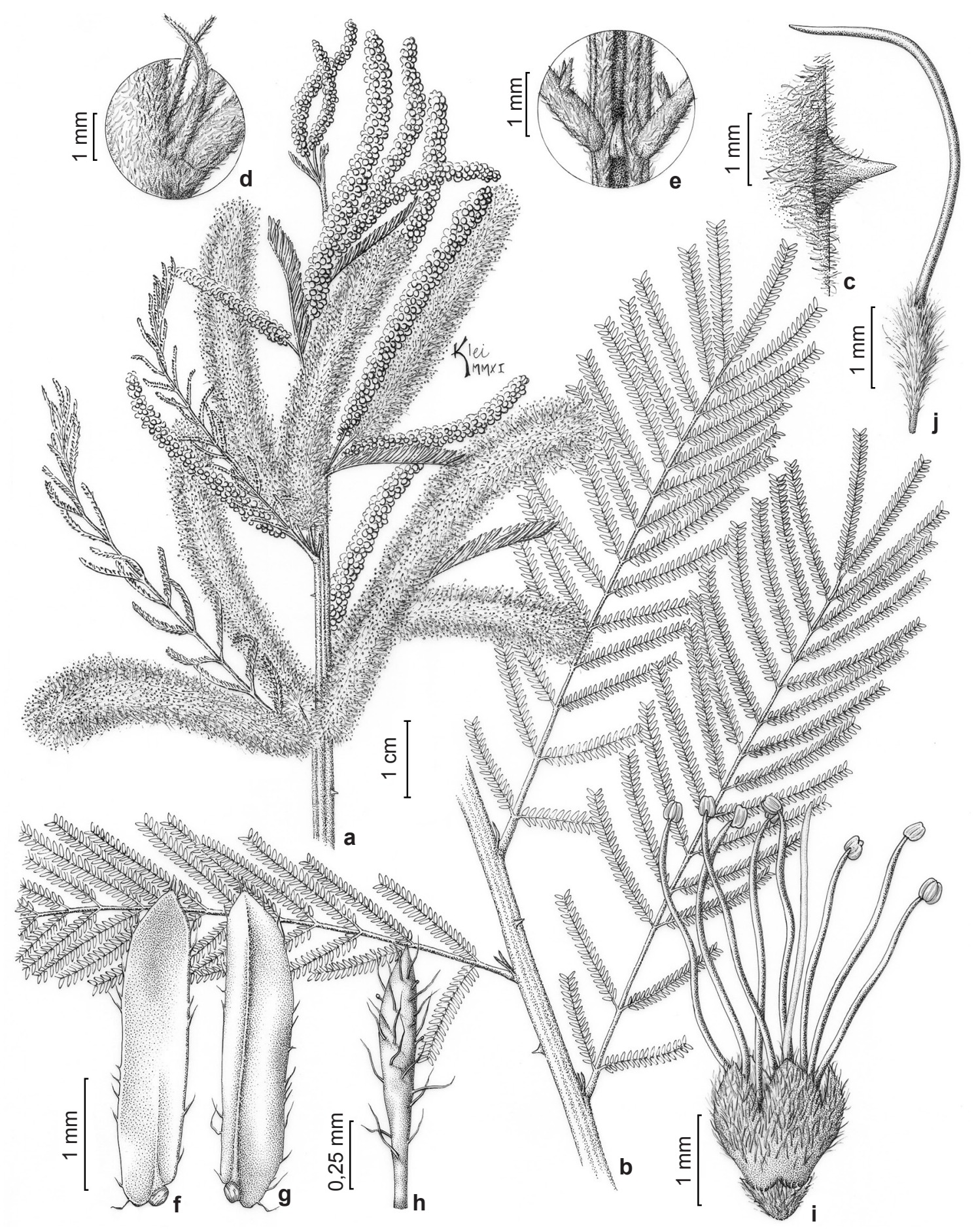

Figura 9-Mimosa hapaloclada - a. ramo forido; b. folhas; c. detalhe do acúleo; d. detalhe das estípulas; e. detalhe da raque mostrando a espícula e os parafilídios; f. foliólulo, face adaxial; g. foliólulo, face abaxial; h. bractéola; i. flor. j. gineceu. (A. Pott 14142).

Figure 9-Mimosa hapaloclada - a. flowering branch; b. leaves; c. detail of aculei; d. detail of stipules; e. detail of leaf rachis, showing spicule and paraphyllidia; f. leaflet, adaxial surface; g. leaflet, abaxial surface; h. bract; i. flower. j. gynoecium. (A. Pott 14142). 


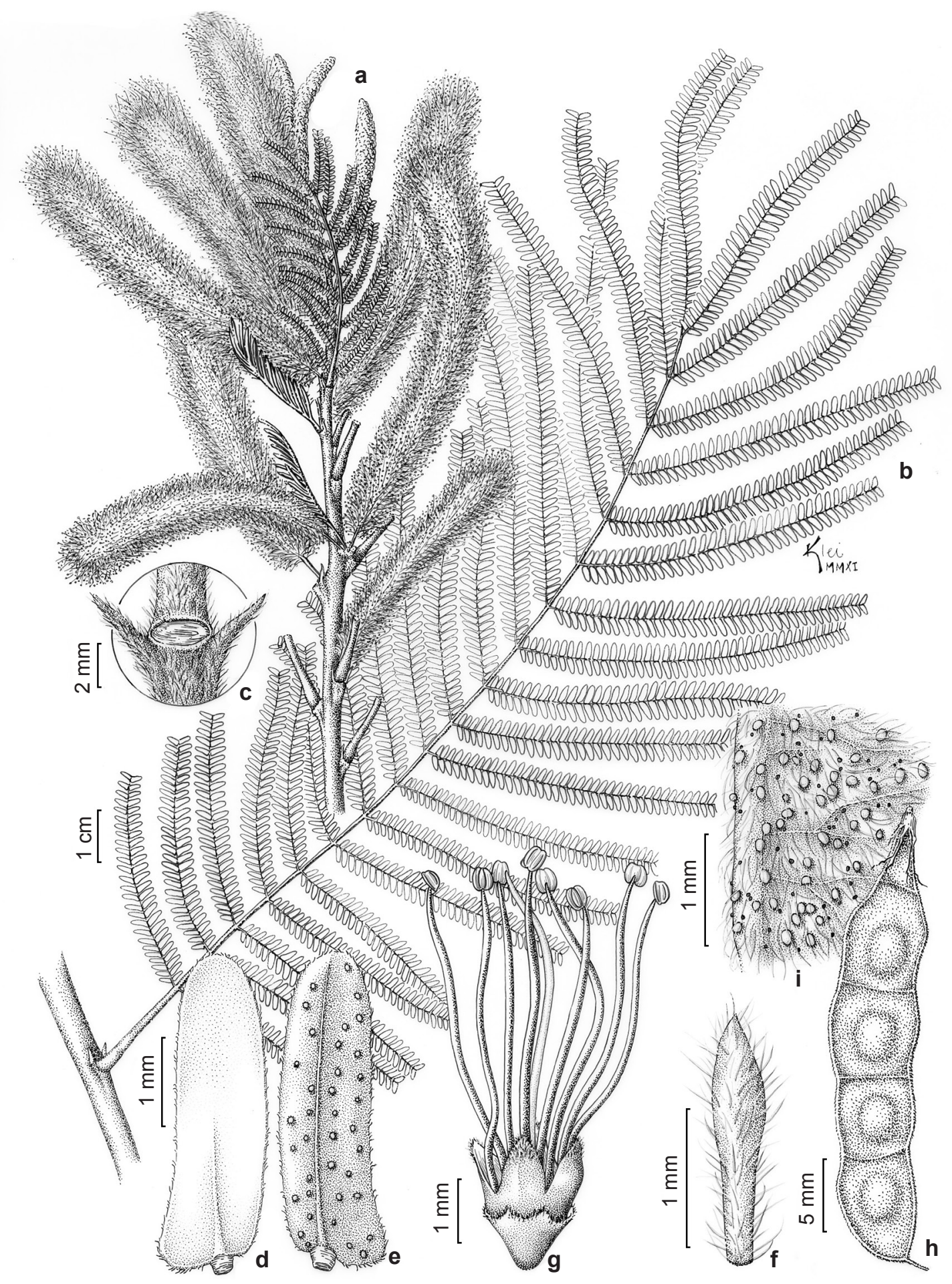

Figura 10 - Mimosa hebecarpa - a. ramo florido; b. folha; c. detalhe das estípulas; d. foliólulo, face adaxial; e. foliólulo, face abaxial; f. bractéola; g. flor; h. fruto; i. detalhe do artículo. (L. C. Romero et al. 114).

Figure 10 - Mimosa hebecarpa - a. flowering branch; b. leaf; c. detail of stipules; d. leaflet, adaxial surface; e. leaflet, abaxial surface; f. bract; g. flower; h. fruit; i. detail of article. (L.C. Romero et al. 114). 
(SP), segundo consta na etiqueta, foram coletados na Bahia. No entanto, acreditamos que esta informação esteja incorreta, haja vista, não ter sido observado nenhum registro desta espécie para este estado. Desenvolve-se, preferencialmente, em áreas de cerrado sobre latossolos em altitudes que variam de 300 a $830 \mathrm{~m}$. Entretanto, também pode ser observada em beira de estradas e rodovias ou ainda em áreas públicas como praças.

Fenologia: Floresce praticamente o ano todo. Frutos foram observados apenas em março, abril, junho e dezembro.

Nome popular: angico, angico-do-cerrado ou angico-do-campo.

Mimosa hebecarpa é uma das espécies mais peculiares de $M$. ser. Leiocarpae s.l., pelo fato das suas inflorescências desenvolverem-se em ramos velhos desfolhados produzidos em estações anteriores aos das folhas. Os ramos jovens ferrugíneos e os folíolos com 28 a 47 pares de foliólulos também auxiliam no seu reconhecimento.

É frequentemente confundida com $M$. gemmulata, podendo ser diferenciada principalmente pela coloração dos ramos jovens, que é marrom-escuro em M. gemmulata e ferrugínea em $M$. hebecarpa. Além disso, esta última espécie possui espigas congestas, corola tomentosa a vilosa e frutos tomentoso-vilosos, características não observadas em $M$. gemmulata . O epíteto específico "hebecarpa" refere-se ao indumento viloso que reveste os frutos.

Material selecionado: BRASIL. SÃO PAULO: Campinas, Instituto Agronômico de Campinas, 20.V.1968, fl., H.M. de Souza (IAC 20070; LP). GOIÁS: Serranópolis, 19.VIII.1998, fl., M.L. Fonseca 1989 (IBGE, NY). MATO GROSSO: Chapada dos Guimarães, 13.X.1973, fl., G.T. Prance, E. Lleras \& D.F. Coelho 18925 (K, NY, US). MATO GROSSO DO SUL: Campo Grande, 09.IV.2010, fr., J.S. Silva 869 (UEC).

15. Mimosa insignis (Hassl.) Barneby, Brittonia 36: 249, fig. 1, 1984. Schranckiastrum insigne Hassl., Repert. Spec. Nov. Regni Veg 16: 152.1919. Tipo: Paraguaria septentrionalis, In Silvulis montains ardis prope Rio perdido, flor. et fruct. Apr 1913, Hassler 11082 (Holótipo: G!; Isótipos: BM!, F!, K!, NY!, W).

Fig. 11

Arbusto $2-3 \mathrm{~m}$ alt.. Ramos inermes, glabros, amarronzados a vináceos. Estípulas 4-4,5 × 0,9-1 $\mathrm{mm}$, estreitamente triangulares a lanceoladas, não ciliada-glandulares. Folhas (4-)7-10 pares de folíolos decrescentes proximalmente; pecíolo
1,5-2 cm compr.; raque 5,5-12,5 cm compr., interrompida entre cada par de folíolos por espícula; segmento da raque 1,2-1,5 cm compr.; foliólulos 68-100 pares, decrescentes proximalmente; ráquila 8-10,5 cm compr., serreada; lâmina 5-10 × $1 \mathrm{~mm}$, cartácea, lanceolada-linear, base oblíqua, ápice agudo, margem não revoluta, curtamente ciliada a não ciliada, concolor, glabra, face abaxial sem pontuações glandulares ou glândulas sésseis, 3-nervada, nervuras mais evidentes na face abaxial sendo uma central e duas submarginais todas atingindo o ápice. Pedúnculo 1-1,5 cm compr.; brácteas ausentes. Espigas (5-)6,5-10 × 0,5 cm, congestas, solitárias a 2 -fasciculadas, nas axilas de folhas totalmente desenvolvidas ou em ramos desfolhados; inflorescências latentes ausentes; bractéolas persistentes, menores que o botão floral, $0,9-1 \times 0,2-0,3 \mathrm{~mm}$, oblanceoladas, côncavas, não ciliada-glandulares. Flores tetrâmeras, bissexuadas, sésseis; cálice $0,9-1 \mathrm{~mm}$ compr., cupuliforme, pubescente; corola 2-3 mm compr., campanulada, pubescente, lacínias eretas; filetes $8-9 \mathrm{~mm}$ compr., unidos na base $\pm 0,5 \mathrm{~mm}$, brancos; ovário 0,8-1 mm compr., estipitado, estípite $2-6 \mathrm{~mm}$ compr., pubescente; estilete $7-8 \mathrm{~mm}$ compr.. Craspédios 6-16 × 0,5 cm, cartáceos, lateralmente tetragonais, 8-11-articulados, sésseis, lineares, base atenuada, ápice agudo, glabros, marrons; artículos quadrangulares, elevados na região das sementes; réplum convexo, constricto entre os artículos dando um aspecto submoniliforme ao fruto, $1-2 \mathrm{~mm}$. Sementes 6-7 ×5 mm, elipsoides, enegrescidas.

Distribuição geográfica e habitat: Esta espécie ocorre na região Centro-Oeste do Brasil (Goiás, Mato Grosso e Mato Grosso do Sul) estendendo-se até ao Paraguai. No território brasileiro cresce em áreas degradadas de cerrado e cerradão sobre solos argilosos, regossolos com ou sem afloramentos rochosos, em altitudes que variam de 180 a $390 \mathrm{~m}$. É frequente nas margens de estradas, rodovias e em áreas de pastagem. Mimosa insignis é conhecida no Paraguai, apenas pela coleção-tipo e não temos nenhuma informação adicional sobre o habitat e ecologia das populações paraguaias.

Fenologia: Floresce em março, maio, setembro, outubro, novembro e frutifica em março.

Nome popular: angiguinho ou jurema-branca.

Mimosa insignis é caracterizada por possuir a ráquila marcadamente serreada, folíolos com elevado número de foliólulos lanceolado-lineares (68-100 pares), 3-nervados, filetes brancos, 
craspédio com os artículos lateralmente tetragonais com réplum largo (1-2 $\mathrm{mm})$, convexo, constricto entre os artículos dando um aspecto submoniliforme aos frutos.

Está espécie compartilha com $M$. dalyi a marcante morfologia dos frutos. No entanto, em $M$. dalyi os foliólulos são menores (2-3,5 mm compr.) e em menor quantidade (30-47) e os filetes são róseos. Além disso, esta espécie possui tricomas lepidotos e folhas com maior número de folíolos (10-17).

O basiônimo de $M$. insignis, Schranckiastrum insigne, foi descrito por Hassler (1919) com base principalmente no fruto. Este autor considerou o réplum e as valvas como sendo uma única estrutura, interpretando erroneamente sua verdadeira morfologia. O fruto, como descrito por Hassler (1919), possuia deiscência elástica com valvas persistentes, características não observadas em Mimosa. Dessa forma, Hassler considerou necessário o estabelecimento de um novo gênero. Provavelmente, os frutos observados por ele estavam imaturos, o que pode ter dificultado a análise das suas estruturas. Posteriormente, Barneby (1984) interpretou os frutos de $S$. insigne como sendo um craspédio diferenciado por apresentar réplum mais alargado e convexo, incluindo Schranckiastrum na sinonímia de Mimosa.

O epíteto específico “insignis” (notável, distinto) refere-se provavelmente a sua ampla folhagem.

Material selecionado: BRASIL. GOIÁS: Matrinchã, 22.III.2006, fl., A. Pott et al. 14130 (UEC). MATO GROSSO: Fazenda Santa Cruz, P 6, 22.X.1980, fl., J.M. Pires \& P.P. Furtado 17225 (INPA, NY, US, MB). MATO GROSSO DO SUL: Bela Vista, BR-262, Km 558 em direção para Porto Murtinho, 10.III.2011, fl. e fr., J.S. Silva \& G. Shimizu 900 (UEC); idem, 10.III.2011, fl. e fr., J.S. Silva \& G. Shimizu 901 (UEC).

16. Mimosa interrupta Benth. J. Bot. (Hooker) 4: 392. 1841. Tipo: Brazil, Pohl s.n. (Holótipo: K-000504858 (hb. Benth.)! = NY )Neg. 1859!; Isótipos: F= F Neg. 54888!; K (Heb. Hook.)!, NY!, W).

Fig. 12

Arbusto a arvoreta $2-7 \mathrm{~m}$ alt.. Ramos aculeados ou menos frequente inermes, quando jovens resinosos, puberulentos a tomentosos, castanhos. Acúleos infranodais distribuídos aos pares, discretamente recurvados. Tricomas simples esbranquiçados, entremeados por glândulas sésseis, lentiformes, acobreadas distribuídos nos ramos, estípulas, folhas, face abaxial dos foliólulos, cálice, corola e frutos. Estípulas $1-1,3 \times 0,2-0,3 \mathrm{~mm}$, triangulares, não ciliada-glandulares. Folhas (4) 7-10 pares de folíolos crescentes; pecíolo 1-1,7 cm compr.; raque 4,5-10 cm compr., interrompida entre cada par de folíolos por espícula; segmento da raque 1-1,5 cm compr.; foliólulos (19-)21-26 pares, decrescentes proximalmente; ráquila 5,5-7 cm compr., sulcada a caniculada; lâmina 6-10 × 1,2-3 mm, subcoriácea, oblonga a estreitamente elíptica, base oblíqua a ligeiramente arredondada, ápice agudo a arredondado, margem não revoluta, curtamente ciliada, discolor, face adaxial verdeescuro, lustrosa com glândulas, sésseis, esparsas, face abaxial verde-oliva, resinosa, 2-4-nervada, nervuras mais evidentes na face abaxial, duas delas podendo atingir o ápice do foliólulo. Pedúnculo 0,5-0,6 cm compr.; brácteas ausentes. Espigas (5-)10,5-12 × 0,4 cm, laxifloras, solitárias a 2 -fasciculadas, nas axilas de folhas jovens ou em ramos desfolhados; inflorescências latentes ausentes; bractéolas persistentes, menores que o botão floral, $0,5-0,6 \times 0,2-0,3 \mathrm{~mm}$, ovais, côncavas, resinosas, não ciliada-glandulares. Flores tetrâmeras, bissexuadas ou menos frequentes unissexuadas, sésseis; cálice 0,5-0,6 mm compr., cupuliforme, resinoso, glabro com glândulas esparsas; corola 1,5-3 mm compr., campanulada, resinosa, glabra, lacínias eretas; filetes 8-9 mm compr., livres brancos; ovário 0,8-1 mm compr., séssil, glabro; estilete 7-8 mm compr.. Craspédios (5) 6-9 × 0,7-1 cm, sublenhosos, 5-11-articulados, sésseis ou curtamente estipitados $(0,2-0,4 \mathrm{~mm}$ compr.), oblongos, base atenuada, ápice mucronado a cuspidado, resinosos, glabros com glândulas, marrom-escuros; artículos quadrangulares ou retangulares, compressos; réplum reto ou constricto entre os artículos, ca. 0,5 mm. Sementes 5-6×4-6 $\mathrm{mm}$, elípticas a ovais, castanhas.

Distribuição geográfica e habitat: Mimosa interrupta ocorre em Goiás, Maranhão e Mato Grosso, crescendo em vegetação de cerrado sobre solo pedrogoso, entre 300 a $700 \mathrm{~m}$ de altitude. É frequente em locais sob a influência da água nas margens do Rio Araguaia e Tocantins. É observada ainda em vegetação secundária e em áreas de pastagem.

Fenologia: flores foram observadas em janeiro, março, abril, maio, setembro e dezembro e frutos em fevereiro, abril, agosto, setembro e dezembro. 

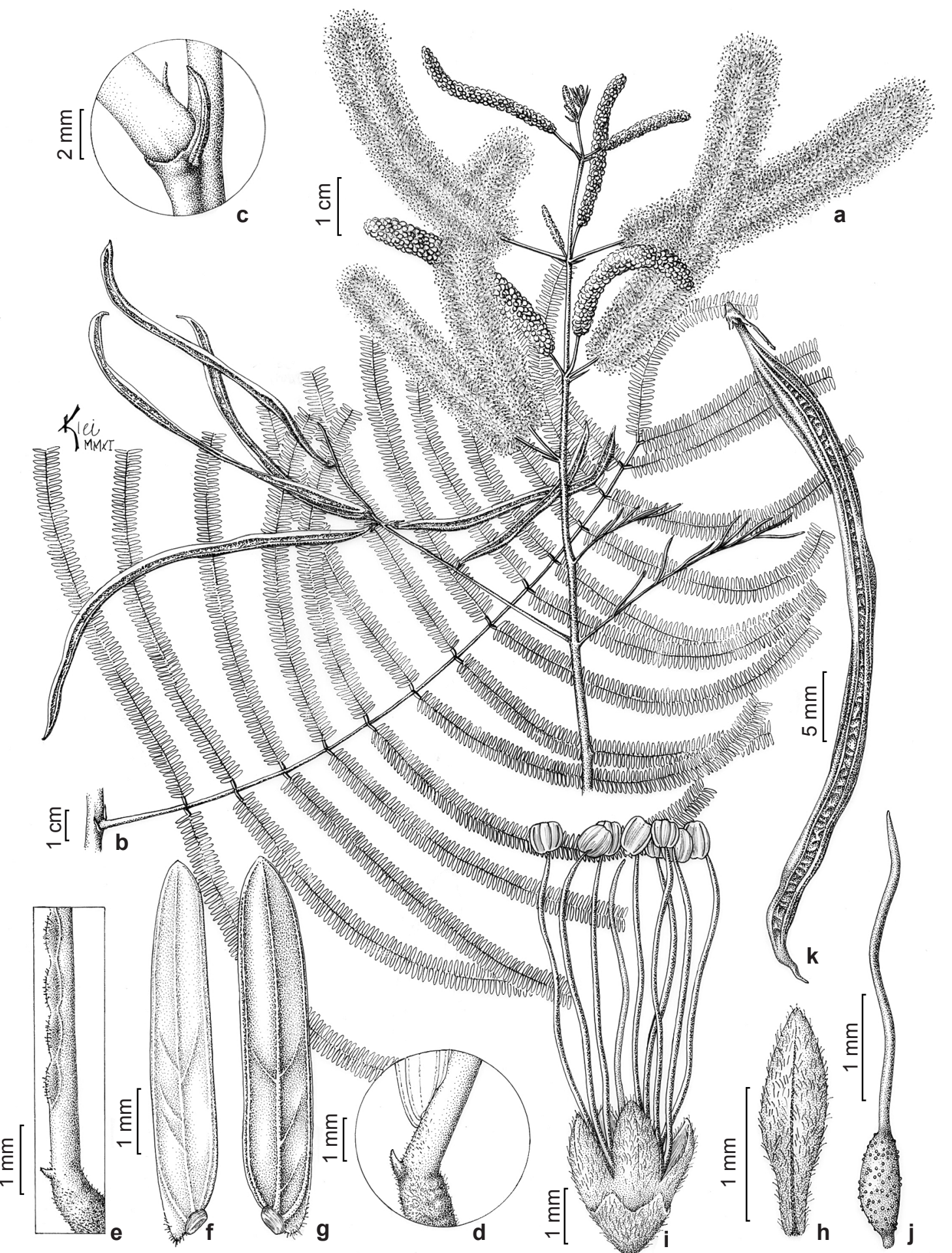


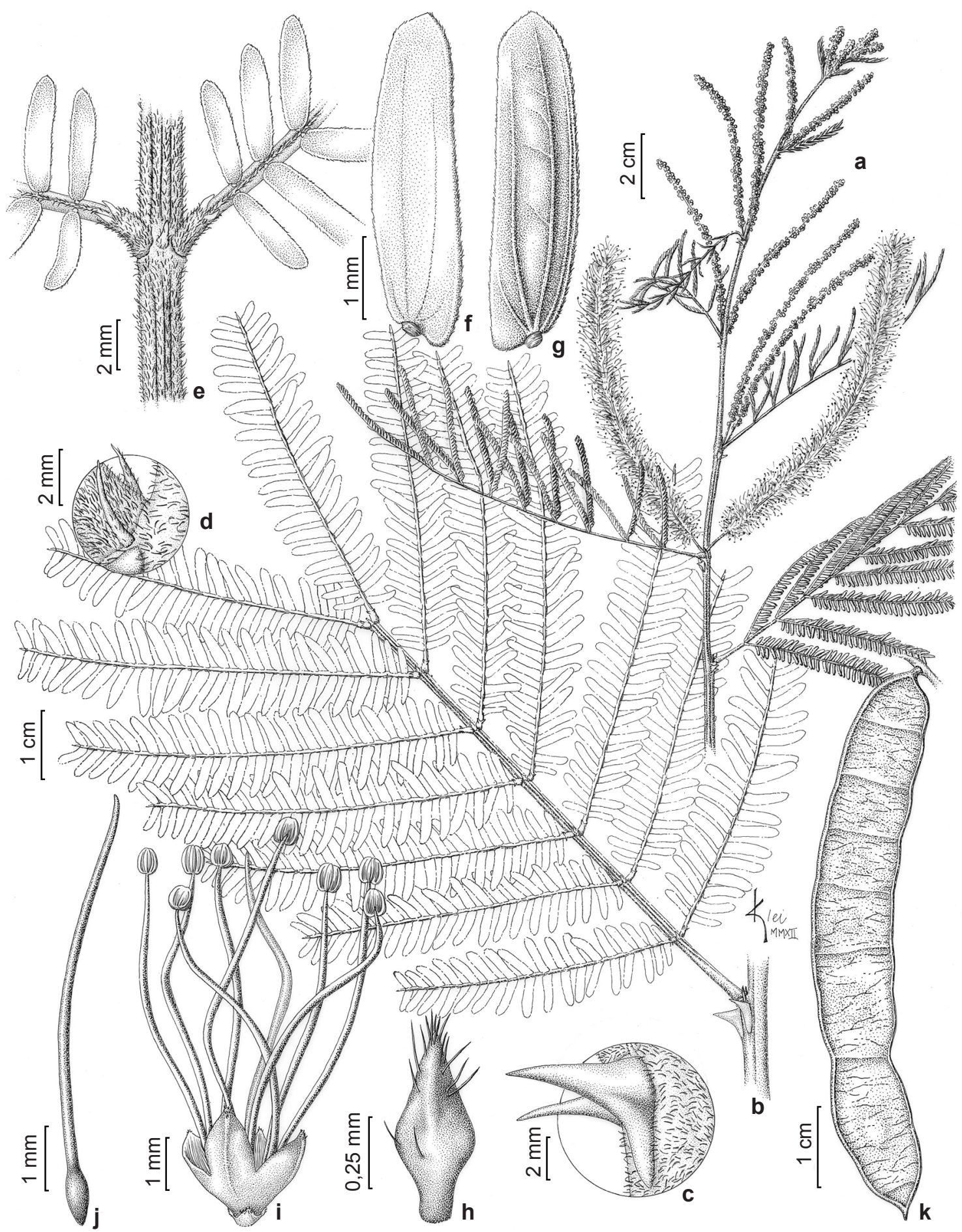

Figura 12 - Mimosa interrupta - a. ramo florido; b. folha; c. detalhe dos acúleos; d. detalhe das estípulas; e. detalhe da raque mostrando a espícula e parafilídios; f. foliólulo, face adaxial; g. foliólulo, face abaxial; h. bractéola; i. flor; j. gineceu; k. fruto. (a-j. A. Pott 14130; k. H.S. Irwin et al. 17606).

Figure 12 - Mimosa interrupta - a. flowering branch; b. leaf; c. detail of aculei; d. detail of stipules; e. detail of leaf rachis, showing spicule and paraphyllidia; f. leaflet, adaxial surface; g. leaflet, abaxial surface; h. bract; i. flower; j. gynoecium; k. fruit. (a-j. A. Pott 14130; k. H.S. Irwin et al. 17606). 
Nome popular: angiquinho ou espinheiro.

Mimosa interrupta apresenta como característica peculiar os foliólulos subcoriáceos com a face adaxial lustrosa e a abaxial resinosa, associados aos frutos compressos, resinosos.

A espécie mais próxima é $M$. glutinosa, porém nesta os foliólulos são cartáceos, com a face adaxial opaca e a abaxial não resinosa. Além disso, possui frutos com artículos elevados na região das sementes. Informações adicionais sobre as diferenças destas espécies são encontradas nos comentários de $M$. glutinosa.

Material selecionado: BRASIL. GOIÁS: Niquelândia, estrada de chão ca. $500 \mathrm{~m}$ abaixo do entroncamento da CODEMN, 15.IV.1996, fr., F.C.A. Oliveira et al. 554 (IBGE, K, NY). MARANHÃO: Carolina, ao longo do Rio Tocantins, 16.IV.1933, fr., B.A. Krukoff 2057 (K, MO, NY). MATO GROSSO: Barra do Garça, Serra do Roncador, 13.XII.1969, fl. e fr., G. Eiten \& L.T. Eiten 9902 (K, NY, SP, US).

17. Mimosa mensicola Barneby, Brittonia 37: 133, 1985. Tipo: Bahia, Sa do Tombador, $\pm 5 \mathrm{Km} \mathrm{S}$ of town of Morro do Chapéu, near base of morro itself at $\pm 1100 \mathrm{~m}, 19$ Feb 1971, fl., H.S. Irwin et al. 32552 (Holótipo: UB!; Isótipos: G, K!, LE, NY!, P, R!, S, US!). $\quad$ Fig. 13

Arbusto 2-5 m alt.. Ramos aculeados, puberulentos a glabrescentes, acinzentados. Acúleos internodais, retos ou discretamente incurvados, presentes também na raque foliar, eixo da inflorescência e ráquila. Tricomas simples esbranquiçados, raramente entremeados por esparsas glândulas curto-estipitadas distribuídos nos ramos, na margem de alguns foliólulos e inflorescências. Estípulas 4-6 × 1-1,2 mm, lanceoladas, não ciliada-glandulares. Folhas 1-2 pares de folíolos discretamente crescentes; pecíolo $0,4-0,7 \mathrm{~cm}$ compr.; raque $0,9-1 \mathrm{~cm}$, interrompida entre cada par de folíolos por espícula; segmento da raque 0,5-1 cm compr.; foliólulos 4-7 pares, crescentes; ráquila $2-3 \mathrm{~cm}$ compr., sulcada; lâmina 12-20 × 4-10 mm, cartácea-coriácea, oblonga a oboval, base e ápice arredondados, margem não revoluta, não ciliada, glabra com glândulas curtoestipitadas esparsadas ao longo da margem, face abaxial sem pontuações glandulares ou glândulas sésseis, 4-7-nervada. Pedúnculo 0,2-0,4 cm compr.; brácteas ausentes. Espigas 2,5-7 × 0,5-0,7 $\mathrm{cm}$, congestas, solitárias a 2-4-fasciculadas, nas axilas de folhas totalmente desenvolvidas ou em ramos desfolhados; inflorescências latentes ausentes; bractéolas caducas, menores que o botão floral, $\pm 1 \times 0,2 \mathrm{~mm}$, ovais a lanceoladas, não ciliada-glandulares. Flores tetrâmeras, bissexuadas, sésseis; cálice $0,8-1 \mathrm{~mm}$ compr., cupuliforme, puberulento; corola 2,6-3 mm compr., campanulada ou cilíndrica, glabra, lacínias eretas; filetes 5-6 mm compr., livres, brancos; ovário $\pm 1 \mathrm{~mm}$ compr., séssil, glabro; estilete 4-5 mm compr.. Craspédios 5-7 × 0,7-1 cm, cartáceo-coriáceos, compressos, 7-8-articulados, sésseis, oblongos, base atenuada, ápice agudo, glabros com glândulas sésseis avermelhadas, vináceos (quando secos amarronzados); artículos quadrangulares ou retangulares; réplum reto, 0,4-0,5 mm, esparsadamente aculeado. Sementes não observadas.

Distribuição geográfica e habitat: espécie endêmica do município do Morro do Chapéu no estado da Bahia, encontrada em campo rupestre, cerrado ou, ainda em áreas antropizadas, associada à solos arenosos ou pedregosos. Mimosa mensicola é uma das espécies que cresce em cotas altitudinais mais elevadas, podendo ser observada em altitudes que variam de 1000 a $1400 \mathrm{~m}$.

Fenologia: Floresce em março e junho. Frutifica em abril, maio, junho.

Mimosa mensicola é facilmente reconhecida por apresentar acúleos retos a discretamente incurvados, distribuídos nos ramos, raque foliar, eixo principal da panícula e ráquila, folhas com 1-2 pares de folíolos e 4-7 foliólulos em cada folíolo. Além disso, apresenta lâmina cartácea-coriácea, com maiores dimensões $(12-20 \times 4-10 \mathrm{~mm}) \mathrm{em}$ comparação com as demais espécies de $M$. ser. Leiocarpae $(1-10 \times 0,4-4 \mathrm{~mm})$ e um maior número de nervuras (4-7 vs. 1-4). Tricomas glandulares curto-estipitados foram observados sobre a margem dos foliólulos, o que também pode auxiliar no reconhecimento desta espécie.

Mimosa mensicola foi descrita por Barneby (1985) que a incluiu em Mimosa sect. Habbasia ser. Leptostachyae devido, principalmente, a presença de espigas longas, cilíndricas e flores tetrâmeras. Posteriormente, Barneby (1991) transferiu parte das espécies da série Leptostachyae - dentre estas M. mensicola - para Mimosa sect. Batocaulon ser. Leiocarpae. Para Barneby (1985), esta espécie é mais próxima a M. acutistipula e M. ophthalmocentra, mas difere principalmente da primeira por apresentar frutos sésseis (vs. estipitado) e da segunda pela corola campanulada ou cilíndrica (vs. 4-angulada). Outras características que também podem auxiliar 


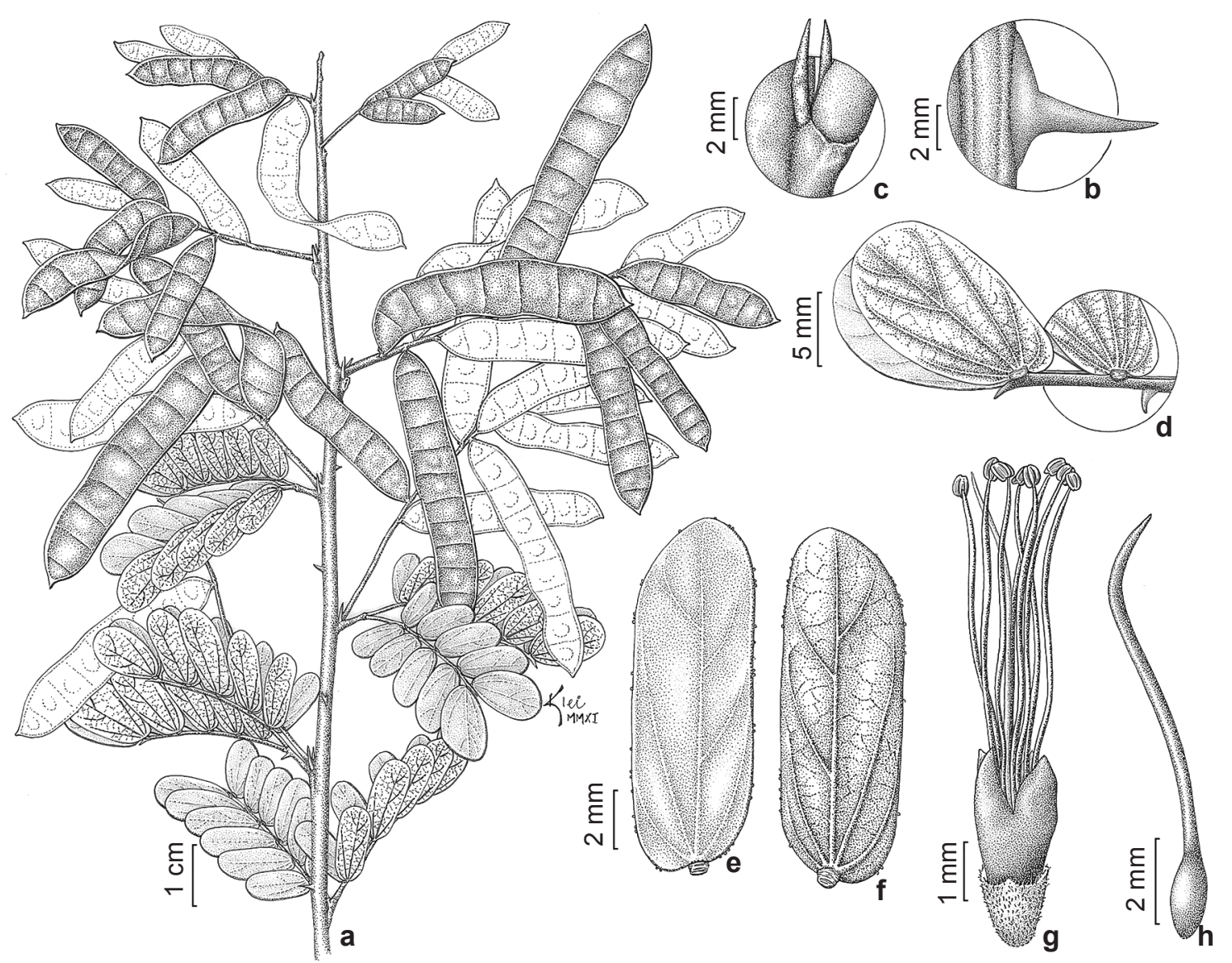

Figura 13 - Mimosa mensicola - a. ramo frutificado; b. acúleo; c. detalhe das estípulas; d. detalhe da raque foliar mostrando o acúleo; e. foliólulo, face adaxial; f. foliólulo, face abaxial; g. flor. h. gineceu. (R.M. Harley 22812). Figure 13 - Mimosa mensicola - a. fruiting branch; b. detail of aculei; c. detail of stipules; d. detail of leaf rachis, showing aculei; e. leaflet, adaxial surface; f. leaflet, abaxial surface; g. flower; h. gynoecium. (R.M. Harley 22812).

na diferenciação destas espécies são número de folíolos e de foliólulos, forma e tamanho da lâmina, as quais foram discutidas nos comentários de $M$. acutistipula e M. ophthalmocentra. Estas espécies também apresentam distribuição geográfica distinta: M. mensicola ocorre apenas no Morro do Chapéu em campo rupestre e cerrado, enquanto $M$. acustistipula e $M$. ophthalmocentra são amplamente distribuídas na região Nordeste, sendo mais associadas à vegetação de caatinga.

$\mathrm{O}$ epíteto "mensicola" (mensa $=$ mesa; $i c o l a=$ que habita) refere-se ao que habita uma montanha em forma de mesa e foi dado em alusão ao formato do Morro do Chapéu, local onde esta espécie foi coletada pela primeira vez.

Material selecionado: BRASIL. BAHIA: Morro do Chapéu, 16.VI.2003, fr., F. França et al. 4687 (HUEFS); Parque Morro do Chapéu, 28.IV.2006, fl., J.M. Gonçalves et al. 17 (HUEFS).
18. Mimosa nothopteris Barneby, Brittonia 37: 133, fig. 2d-e, 1985. Tipo: Bahia, trackway from rodovia BR 235 to Curral Novo on route to Fundação Ruralista in SE Piauí, 15 Jan 1982, G.P. Lewis \& H.P.N. Pearson 1074 (Holótipo: CEPEC; Isótipos: K!, NY!, RB!).

Fig. 14

Arbusto $1,5 \mathrm{~m}$ alt.. Ramos aculeados, puberulentos, marrons, quando jovens castanhos. Acúleos infranodais ou internodais, às vezes estendendo-se até a raque foliar, solitários ou distribuídos aos pares, retos, com base larga. Tricomas simples esbranquiçados, entremeados por glândulas sésseis, lentiformes, amarelotranslúcidas a acobreadas, distribuídas nos ramos, estípulas, raque foliar, face abaxial dos foliólulos, eixo das inflorescências, bractéolas, corola e ovário. Estípulas $2-3 \times 0,2 \mathrm{~mm}$, subuladas, não ciliada-glandulares. Folhas 4-10 pares de folíolos 


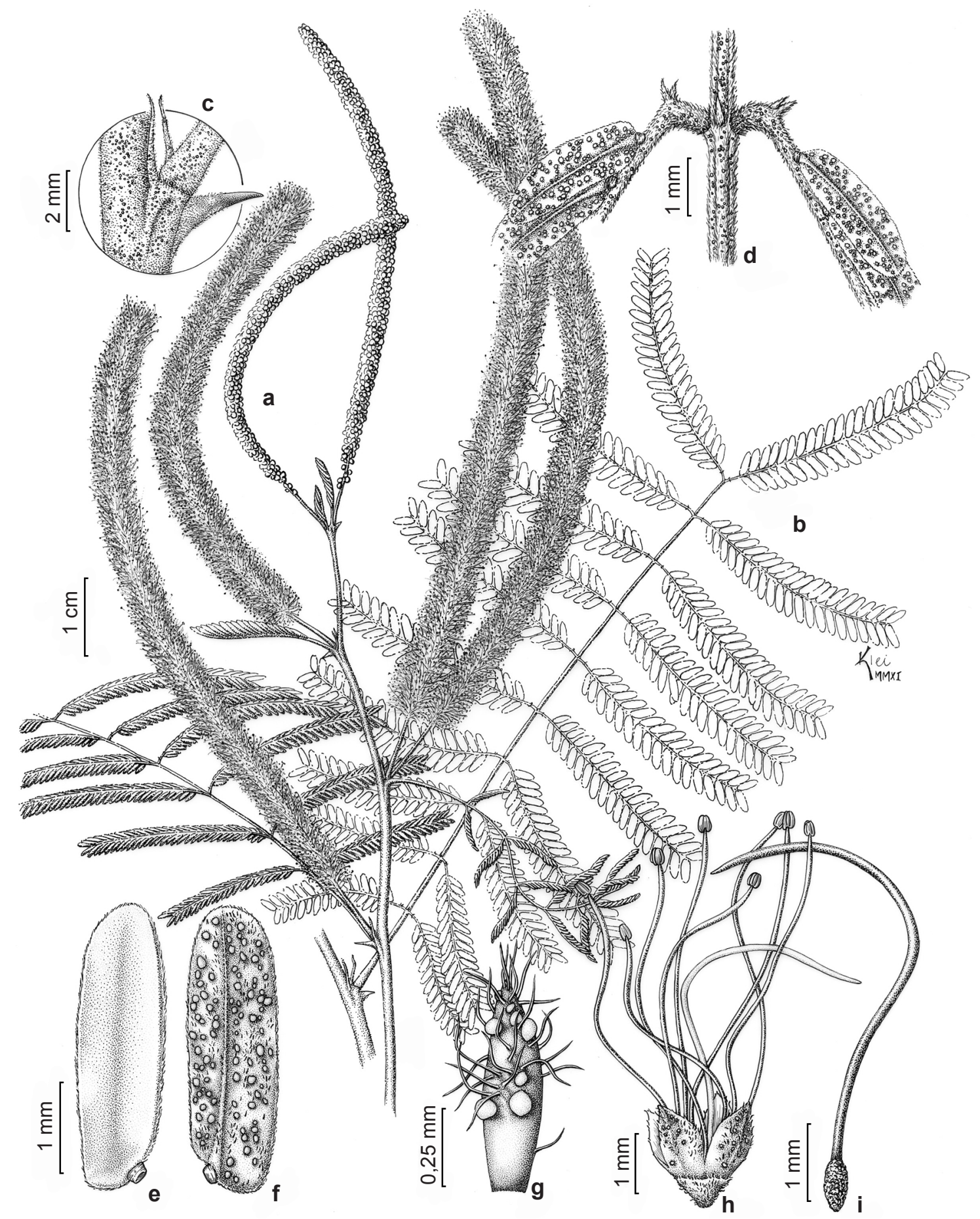

Figura 14 - Mimosa nothopteris - a. ramo florido; b. folha; c. detalhe estípulas; d. detalhe da raque foliar mostrando a espícula e os parafilídios; e. foliólulo, face adaxial; f. foliólulo, face abaxial; g. bractéola; h. flor; i. gineceu. $(J$. Paula-Souza et al. 5204).

Figure 14 -Mimosa nothopteris - a. flowering branch; b. leaf; c. detail of stipules; d. detail of leaf rachis, showing spicule and paraphyllidia; e. leaflet, adaxial surface; f. leaflet, abaxial surface; g. bract; h. flower; i. gynoecium. (J. Paula-Souza et al. 5204). 
crescentes; pecíolo 1-1,5 cm compr.; raque 3,5-9 $\mathrm{cm}$, interrompida entre cada par de folíolos por espícula; segmento da raque $0,6-0,7 \mathrm{~cm}$ compr.; foliólulos 9-23 pares, crescentes; ráquila 1,5-2,6 cm compr., cilíndrica; lâmina $3-5 \times 1-1,4 \mathrm{~mm}$, cartácea, oblonga, base oblíqua a arredondada, ápice agudo, margem não revoluta, ciliada, face adaxial glabra, face abaxial pubescente, 1-nervada, nervura atingindo o ápice. Pedúnculo 0,7-0,9 $\mathrm{cm}$ compr.; brácteas ausentes. Espigas 6-9 $\times$ 0,4-0,5 cm, laxifloras a congestas, solitárias a 2-fasciculadas, nas axilas de folhas jovens ou totalmente desenvolvidas; inflorescências latentes ausentes; bractéolas caducas, menores que o botão floral, 0,5-1 ×0,2 mm, oblanceoladas, não ciliadaglandulares. Flores tetrâmeras, bissexuadas ou frequentemente unissexuadas, sésseis; cálice 0,40,8 mm compr., cupuliforme, puberulento; corola 1,5-2 mm compr., campanulada, puberulenta, lacínias eretas; filetes 6-7 $\mathrm{mm}$ compr., livres, róseos; ovário 0,8-1 mm compr., séssil, glandularpapilado; estilete 5-6 mm compr.. Craspédios não observados.

Distribuição geográfica e habitats: Espécie endêmica da Bahia, com registro apenas para os municípios de Dom Basílio, Livramento do Brumado e Curral Novo. É encontrada em áreas de caatinga degradada, sobre solo alaranjado, em até $350 \mathrm{~m}$ de altitude.

Fenologia: coletada com flores em janeiro, março e novembro.

Pode ser reconhecida por ser um arbusto com ramos aculeados, cujos acúleos podem ser infranodais ou internodais, solitários ou distribuídos aos pares, folhas com 4-10 pares de folíolos, face abaxial dos foliólulos com glândulas, flores frequentemente unissexuais, cálice cupuliforme sem dentes aparentes, filetes róseos e ovário glandular-papilado. Nenhuma coleção com fruto de $M$. nothopteris pôde ser analisada.

Mimosa nothopteris pode ser confundida com M. gemmulata, com a qual compartillha a presença de glândulas na face abaxial dos foliólulos e as flores rosadas reunidas em longas espigas. No entanto, $M$. nothopteris pode ser distinta pelos ramos aculeados ( $v s$. ramos inermes), menor número de folíolos (4-10 pares vs. 9-21), cálice sem dentes aparentes (vs. cálice discretamente denteado) e ovário glandular-papilado (vs. ovário pubescente a viloso).

O epíteto específico "nothopteris" (notho $=$ falso e pteris = asa, ala ou pena) provavelmente foi usado em alusão ao aspecto de asa que as folhas do holótipo apresentam.

Material selecionado: BRASIL. BAHIA: Dom Basílio, ca. 17 km S de Livramento do Brumado, 29.X.1993, fl., L.P. de Queiroz \& N.S. Nascimento 3694 (K, HUEFS); Livramento do Brumado, $20 \mathrm{~km} \mathrm{~S}$ de Livramento do Brumado, 26.III.1991, fl., G.P. Lewis \& S.M.M. de Andrade 1886 (CEPEC, K, NY, RB).

19. Mimosa ophthalmocentra Mart. ex Benth., Trans. Linn. Soc. London 30: 415.1875. Tipo: Brazil, prov. Bahia, Vila Nova da Rainha, Martius 414 (Lectótipo: foto M! designado por Barneby [1991: 130] = NY Neg. 11511!). Fig. 15a-h

Arbusto a arvoreta 1,5-6 m alt.. Ramos aculeados a inermes, puberulentos, castanhos a acinzentados. Acúleos internodais, retos, com base larga. Tricomas simples esbranquiçados, às vezes, intercalados por tricomas glandulares sésseis a curto-estipitados distribuídos nos ramos. Estípulas $2-7 \times 0,5-1 \mathrm{~mm}$, subuladas a estreitamente triangulares, não ciliada-glandulares, 3-nervadas. Folhas 2-5 pares de folíolos crescentes; pecíolo 0,4-1,2 cm compr.; raque $1-3 \mathrm{~cm}$, interrompida entre cada par de folíolo por espícula; segmento da raque $0,4-1 \mathrm{~cm}$ compr.; foliólulos 11-24 pares, crescentes a decrescentes proximalmente; ráquila 1,5-4 cm compr., sulcada; lâmina 4,5-9 × 1-1,5 $\mathrm{mm}$, cartácea, oblonga, base oblíqua a arredondada, ápice agudo, margem não revoluta, discretamente ciliada, glabra, face abaxial sem pontuações glandulares ou glândulas sésseis, 3-nervada, nervuras mais evidentes na face abaxial, quando em número de duas, uma delas é pouco evidente e não atinge o ápice. Pedúnculo 0,4-0,5 cm compr.; brácteas ausentes. Espigas 2,5-8 × 0,4-0,5 cm, congestas, solitárias a 2-fasciculadas, nas axilas de folhas jovens ou totalmente desenvolvidas e em ramos desfolhados; inflorescências latentes ausentes; bractéolas caducas, menores que o botão floral, 1-1,5 × 0,2 mm, lanceoladas, não ciliada-glandulares. Flores tetrâmeras, bissexuadas, sésseis; cálice 0,7-1 mm compr., cupuliforme, glabro a puberulento; corola 2,8-3 mm compr., tubulosa, 4-angulada por nervura proeminente e incurvada, glabra, lacínias côncavas; filetes 5-6 mm compr., livres, brancos; ovário 0,8-1 mm compr., séssil, glabro; estilete 5-6 mm compr.. Craspédios 3-6 × 0,5-0,8 cm, cartáceo-coriáceos, compressos, 4-8-articulados, sésseis, oblongos, base atenuada a arredondada, ápice agudo a discretamente mucronado, glabros com esparsos 
tricomas glandulares sésseis, dando aspecto resinoso na região onde ocorrem, castanhos a vináceos; artículos quadrangulares; réplum reto, 0,4-0,5 mm. Sementes 2,8-3,8 × 2,6-3 mm, orbiculares, marrons.

Distribuição geográfica e habitat: Ocorre em áreas de caatinga da Bahia, Ceará, Paraíba, Pernambuco e Rio Grande do Norte, sobre solos arenosos, argilosos ou pedregosos, em altitudes que variam de 100 a $800 \mathrm{~m}$. Existem ainda registros pontuais em Minas Gerais e alguns indivíduos são cultivados na Estação Experimental da Biologia UnB, em Brasília, de sementes oriundas do estado de Pernambuco.

Mimosa ophthalmocentra destaca-se por ser uma das espécies de Leiocarpae s.l. mais bem amostrada nos herbários nacionais e estrangeiros. Observamos um número elevado de exsicatas oriundas especialmente da região Nordeste, onde esta ocorre com maior frequência.

Fenologia: floresce e frutifica praticamente o ano inteiro.

Nome popular: angelim-cheiroso, jurema, jurema-branca, jurema-de-imbira, calumbívermelho.

Mimosa ophthalmocentra é a única espécie com estípulas 3-nervadas e corola 4-angulada devido a presença de nervuras proeminentes e incurvadas, cujas lacínias são côncavas. As folhas com dois a cinco pares de folíolos, cada uma com 11 a 24 pares de foliólulos e os frutos sésseis, castanhos a vináceos, com esparsos tricomas glandulares sésseis também auxiliam no seu reconhecimento.

É comumente confundida com $M$. acutistipula, M. arenosa e $M$. tenuiflora, espécies presentes também na caatinga. Da primeira, M. ophthalmocentra pode ser distinguida principalmente pelos frutos sésseis, enquanto $M$. acutistipula apresenta frutos estipitados. De $M$. arenosa se distingue também pelos fruto sésseis (vs. estipitados) e pelas folhas com menor número de folíolos (2-5 pares em $M$. ophthalmocentra vs. 4-14 em M. arenosa). Já de M. tenuiflora pode ser diferenciada pelo cálice cupuliforme e pelos frutos compressos ( $v s$. cálice tubuloso, 4-angulado por nervura proeminente e incurvada e pelo frutos inflados na região das sementes).

O espécime citado por Barneby (1991), Martius 538 (M!), como provável duplicata do material tipo de $M$. ophthalmocentra, não foi considerado no presente trabalho como isolectótipo, pois foi coletado em uma outra localidade (Piauhy in pascuis).

A razão do epíteto "ophthalmocentra" é desconhecida, no entanto ophthalmo significa olho e kentrum espinho.

Material selecionado: BRASIL. BAHIA: Anajé, Serra do Pombos, 14.V.1983, fl., G. Hatschbach 46347 (BM, K, MBM, US). CEARÁ: Quixeré, 17.VI.1997, fl. e fr., E.O. Barros, L.M.R. Barros \& L.W. Lima-Verde 143 (EAC, HUEFS, K). DISTRITO FEDERAL: Brasília, Bacia do Rio São Bartolomeu, 18.II.1981, fl., E.P. Heringer et al 6265 (IBGE, K, US). MINAS GERAIS: Montes Claros, BR 262 em direção a Aracatú, 12.XII.1984, fl., G.P. Lewis et al. s.n (K, SPF). PARAIÍBA: Campina Grande, São José da Mata, 25.VI.1990, fl. e fr., M.F. Agra 1131 (K, MO). PERNAMBUCO: Mirandiba, Serra das Umburanas, 18.IV.2007, fl., J.S. Silva et al. 193 (UFP, HUEFS). PIAUÍ: São Raimundo, Fudação Ruralista, 17.I.1982, fl., G.P. Lewis \& H.P.N. Pearson 1101 (K). RIO GRANDE DO NORTE: Mossoró-Canto da Vara, 19.VII.1961, fl. e fr., S. Tavares 675 (HST, US).

20. Mimosa pteridifolia Benth., J. Bot. (Hooker) 4: 391. 1841. Tipo: ad Fazenda do Cap. Vincente et Lavrinhas, Pohl s.n. (Lectótipo: K-000504855 (hb. Hook.)! = IPA Neg. 1273, designado por Barneby [1991: 144]; Isolectótipos: NY!, W).

Mimosa pteridifolia var. affinis Rizz., Rodriguésia 55: 17. 1980. Tipo: Mato Grosso, via XavantinaSão Félix, $2 \mathrm{Km} \mathrm{N}$. of the base Campo of the Expedition, 1 May 1968, R.R. dos Santos et al. 1227 (Holótipo: RB!; Isótipos: K, NY!).

Mimosa pteridifolia var. paucipinnata Rizz., Rodriguésia 55: 17. 1980. Tipo: Mato Grosso, 270 Km N. of Xavantina, 29 May 1968, J.A. Ratter et al. 1581 (Holótipo: RB!; Isótipo: NY!).

Mimosa adenophylla Taub., Flora 75: 72. 1892. Tipo: Brasilia austro-orientali loco non indicato, A. Glaziou 12645 (Lectótipo: B = F Neg. 1394, designado por Barneby [1991: 146]; Isolectótipos: C, F! = F Neg. 54799!, K!), syn. nov.

Mimosa adenophylla var. armandiana (Rizz.) Barneby, Brittonia 37: 129. 1985, baseado em $M$. pteridifolia var. armandina Rizz., Rodriguésia 55: 17, fig. 5, 1980. Tipo: Minas Gerais, Itaobim, Vale do Rio Jequinhonha, 2 Abr 1979, A. Mattos Filho \& C.T. Rizzini s.n. (Holótipo: RB-188974!), syn. nov. Mimosa adenophylla var. mitis Barneby, Brittonia 37: 130. 1985. Tipo: Bahia, mun. Sento Sé, Serra do Angelim, $10^{\circ} 37^{\prime} \mathrm{S}, 41^{\circ} 28^{\prime} \mathrm{W}, 2$ Set 1981, J.D.C. Arouck Ferreira 79 (Holótipo: K!; Isótipos: NY, RB), syn. nov.

Fig. 15i-p

Subarbusto a arvoreta 1,5-4 m alt.. Ramos aculeados a inermes, glabrescentes a tomentosos, 
castanhos, quando jovens ferrugíneos. Acúleos internodais, estendendo-se até a raque foliar, retos a retrosos. Tricomas simples esbranquiçados a amarelados, intercalados por glândulas sésseis, esféricas a lentiformes, amarelo-translúcidas a acobreadas distribuídos nos ramos, face abaxial dos foliólulos, raque foliar, eixo da inflorescência, bractéolas, cálice, corola, ovário e frutos. Estípulas 2-12 × 0,5-3 mm, subuladas a lanceoladas, não ciliada-glandulares. Folhas 5-26 pares de folíolos crescentes; pecíolo $0,5-1,5 \mathrm{~cm}$ compr.; raque $3,5-15 \mathrm{~cm}$, interrompida ou não entre os pares de folíolos distais por espícula; segmento da raque 0,5 1,5 cm compr.; foliólulos 18-40 pares, decrescentes proximalmente; ráquila $3-7 \mathrm{~cm}$ compr., sulcada a cilíndrica; lâmina 2-7 × 1-3 mm, cartácea, oblonga, base truncada, ápice arredondado, margem frequentemente revoluta, ciliada a não ciliada, discolor, às vezes, discretamente dorso-convexa, face adaxial verde-escuro, glabra, pubescente a tomentosa, face abaxial verde-oliva, glabrescente a pubescente, com tricomas normalmente sobre as nervuras, 1-2-nervada, quando em número de duas, uma delas é pouco evidente e não atinge o ápice. Pedúnculo 0,8-1,5 cm compr.; brácteas ausentes. Espigas 3,5-11,5 × 0,2-0,5 cm, congestas, solitárias a 2-3-fasciculadas, reunidas em panícula terminal, nas axilas de folhas jovens ou em ramos desfolhados; inflorescências latentes ausentes; bractéolas persistentes, menores que o botão floral, 0,4-1 × 0,3 mm, oblanceoladas a ovais, não ciliada-glandulares. Flores tetrâmeras, bissexuadas, sésseis; cálice 0,5-1 mm compr., cupuliforme, glabrescente a pubescente; corola 2-2,4 mm compr., campanulada, glabra ou pubescente-tomentosa, lacínias eretas; filetes 6-8 mm compr., livres ou raramente unidos $( \pm 0,3$ $\mathrm{mm}$ ), róseos; ovário $0,8-1 \mathrm{~mm}$ compr., séssil, viloso; estilete 5-8 mm compr.. Craspédios 2-5 $\times$ 0,4-1 cm, cartáceos, 3-7-articulados, sésseis, oblongos a lineares, base atenuada a arredondada, ápice mucronulado, vilosos a lanosos, castanhos; artículos quadrangulares ou elípticos, compressos; réplum reto constricto entre os artículos, 0,3$0,4 \mathrm{~mm}$. Sementes $2,8-3,8 \times 2,6-3 \mathrm{~mm}$, orbiculares, marrons.

Distribuição geográfica e habitat: Mimosa pteridifolia ocorre nos estados da Bahia, Ceará, Distrito Federal, Goiás, Mato Grosso, Minas Gerais, Pernambuco e Tocantins, em caatinga, cerrado, floresta estacional ou em áreas de transição cerradofloresta estacional, sobre solos arenosos, argilo- arenoso ou em afloramento rochoso, em altitudes que variam de 550 a $1070 \mathrm{~m}$. É frequentemente encontrada em ambientes degradados, como margem de estradas e rodoviárias. Barneby (1991), citou ainda a ocorrência para Venezuela, no entanto não foi analisada nenhuma população deste país.

Fenologia: Flores são observadas de janeiro a agosto e em outubro e dezembro, enquanto frutos em junho, julho e setembro.

Nome popular: jurema, jurema-cor-de-rosa, malícia.

Mimosa pteridifolia é facilmente reconhecida pela semelhança das suas folhas com as das pteridófitas, apresentando de 5 a 26 pares de folíolos e 18 a 40 pares de foliólulos. Nesta espécie, os foliólulos podem apresentar a margem revoluta e ser discretamente dorso-convexos. As espigas são reunidas, predominantemente, em panícula terminal ou em ramos desfolhados, os filetes são róseos e os frutos são sésseis e vilosos.

Pode ser confundida com M. gemmulata por compartilharem o hábito subarbustivo a arbóreo, folhas com mais de nove pares de folíolos, a presença de glândulas sobre as estruturas vegetativas e reprodutivas e a coloração rosada dos filetes. No entanto, diferencia-se por apresentar foliólulos maiores $(2-7 \times 1-3 \mathrm{~mm} v \mathrm{~s} .1,2-2 \times 0,5-2 \mathrm{~mm}) \mathrm{com}$ base truncada ( $v s$. oblíqua), espigas frequentemente reunidas em panículas (vs. espigas nas axilas de folhas jovens ou totalmente desenvolvidas ou, menos frequentemente, em ramos desfolhados) e frutos vilosos (vs. glabrescentes).

Mimosa pteridifolia foi descrita por Bentham (1841) com base em três síntipos: Brazil, Pohl; Serra Acurua, Blanchet, n. 2850 e Prov. Goyaz, Gardner, n. 4123. Posteriormente, Bentham (1876) acrescentou os seguintes dados sobre o local de coleta das coleções supracitadas, respectivamente: Provinciae Goyaz, in campis arenosis prope Capilla de Passé; ad Fazenda do Cap. Vincente et Lavrinhas e Provinciae Bahiensis, Serra Açurua. Barneby (1991) elegeu a coleta de Pohl 1421 depositado no Herbário Hookerianum (K) como lectótipo. Para este autor, o número de coleta desta coleção corresponde a Pohl d. $1421=1728$. No entanto, analisando este material observamos que existem dois números distintos de coleta - Pohl 1392 e Pohl 1421 - escritas a lápis, sendo uma na própria exsicata e outra em uma etiqueta à parte, respectivamente. Além disso, na provável duplicata de Pohl 1421, depositada em NY, existe um terceiro número (Pohl 1728), o que coloca em 
dúvida qual seria realmente a numeração da coleta de Pohl realizada na ad Fazenda do Cap. Vincente et Lavrinhas (= on Rio das Almas, $15^{\circ} \mathrm{S}, 49^{\circ} 10 \mathrm{~W}$ in centr. Goiás, segundo Barneby (1991). Diante disso, concordamos com a lectotificação realizada por Barneby (1991), entretanto, achamos pertinente não incluir nenhuma numeração à coleta de Pohl e citar a informação assim como mencionada no protólogo de M. pteridifolia (Pohl s.n).

Mimosa pteridifolia é bastante polimórfica com relação ao número de folíolos e foliólulos, fato que levou Rizzini (1980) a reconhecer para esta espécie quatro variedades: M. pteridifolia var. nanophylla, M. pteridifolia var. paucipinnata, $M$. pteridifolia var. armandiana e $M$. pteridifolia var. affinis. Barneby (1991) não reconheceu nenhum destes táxons e os incluiu na sinonímia de $M$. adenophylla (M. pteridifolia var. armandiana), M. gemmulata (M. pteridifolia var. nanophylla) e M. pteridifolia (M. pteridifolia var. affinis e M. pteridifolia var. paucipinnata). Além disso, considerou $M$. adenophylla e $M$. pteridifolia muito próximas morfologicamente e as tratou como entidades distintas.

Mimosa adenophylla foi estabelecida por Taubert (1892), baseada na coleção de A. Glaziou 12645. Tanto este autor quanto Barneby (1985; 1991) consideraram $M$. pteridifolia como a espécie mais relacionada morfologicamente a $M$. adenophylla, podendo esta última ser diferenciada especialmente pela presença de acúleos e espículas entre alguns pares de folíolos mais distais, menor número de folíolos (4-12 vs. 9-26) e foliólulos maiores (4-9 mm vs. 3,5-5 mm). Após a análise de diversos materiais nos herbários e da observação em campo, notou-se que o número de folíolos varia em um mesmo indivíduo e que esta variação não é descontínua. Além disso, verificou-se sobreposição dos valores referentes ao tamanho dos foliólulos, os indivíduos podem ser aculeados ou inermes e as espículas realmente estão presentes em alguns pares de folíolos mais distais, porém existem folhas que não possuem tais estruturas e quando presentes são de difícil visualização. Pela ausência de características morfológicas que sustentem tais espécies como táxons distintos, propõe-se neste trabalho a sinonimização de $M$. adenophylla em M. pteridifolia.

Barneby (1985) estabeleceu duas variedades em Mimosa adenophylla: M. adenophylla var. armandiana e $M$. adenophylha var. mitis, baseado na presença de acúleos sobre os ramos (ausentes na var. mitis), no indumento dos foliólulos (viloso na face adaxial na var. adenophylla vs. glabra nas demais) e no número de lacínias da corola (5 na var. típica vs. 4 nas demais) e de estames (10 na var. típica vs. 8 nas demais). Informações sobre a distribuição geográfica também foram utilizadas: M. adenophylla var. armandiana ocorre do sul da Bahia até o norte de Minas Gerais, M. adenophylla var. adenophylla apenas em Minas Gerais e $M$. adenophylha var. mitis em Pernambuco e Ceará. No entanto, estas características não se mostraram consistentes na análise de maior quantidade de material. Por exemplo, flores pentâmeras não foram encontradas na variedade típica e a presença de acúleos e o indumento dos foliólulos estão relacionados com o habitat e fase de crescimento dos indivíduos. Em Pernambuco (Buíque), observamos no mesmo indivíduo ramos aculeados e inteiramente inermes. Acreditamos que em M. adenophylla, os acúleos estejam presentes apenas nas fases iniciais de crescimento dos seus indivíduos e que, à medida que eles crescem em altura estas estruturas vão se tornando menores até não mais se formarem. Assim, co-identificamos estas variedades em $M$. pteridifolia.

O epíteto específico "pteridifolia" foi empregado em alusão a semelhança das suas folhas com as de algumas espécies de pteridófitas.

Material selecionado: BRASIL. BAHIA: Formoso do Rio Preto, 26.IV.1990, fr., H.P. Bautista 1500 (HUEFS, IBGE, RB). DISTRITO FEDERAL: Parque Nacional de Brasília, 30.V.1973, fl., E.P. Heringer et al. 12783 (UB, RB). GOIÁS: Cabeceira, s. loc., 25.V.2012, fl., J.S. Silva \& H. Moreira 1178 (CEN, HUNEB, UEC); Planaltina de Goiás, estrada São Gabriel, 8.V.2012, fl., J.S. Silva \& H. Moreira 1196 (CEN, HUNEB, UEC); Ponte Alta do Bom Jesus, 70 km de Dianópolis, 12.V.2012, fl., J.S. Silva \& H. Moreira 1170 (CEN, HUNEB, UEC); Teresina de Goiás, depois do Rio Paranoã, Km 177, 8.V.2012, fl., J.S. Silva \& H. Moreira 1102 (CEN, HUNEB, UEC). MATO GROSSO: Rio Turvo, ca. $200 \mathrm{Km}$ N. de Xavantina entre a estrada Xavantina-São Felix, 4.VI.1968, fr., R.R. de Santos \& R. Souza s.n. (RB 165727). MATO GROSSO DO SUL: Coxim, 3.V.1995, fl., G. Hatschbach 62158 (MBM, SPF). MINAS GERAIS: Chapada Gaúcha. Parque Nacional Grande Sertão Vereda, 25.V.2012, fl. e fr., J.S. Silva \& H. Moreira 1188 (CEN, HUNEB, UEC). PERNAMBUCO: Buíque, Vale do Catimbau, 28.VI.2011, fr., J.S. Silva \& P.P.A. Silva 988 (UEC).

21. Mimosa schomburgkii Benth., J. Bot. (Hooker) 2: 133. 1840. Tipo: Pirara, British Guiana, Schomburgk 715 (Holótipo: K (hb. Benth.)! = NY Neg. 1854!; Isótipos: G, F (533383; 533122)! = F 


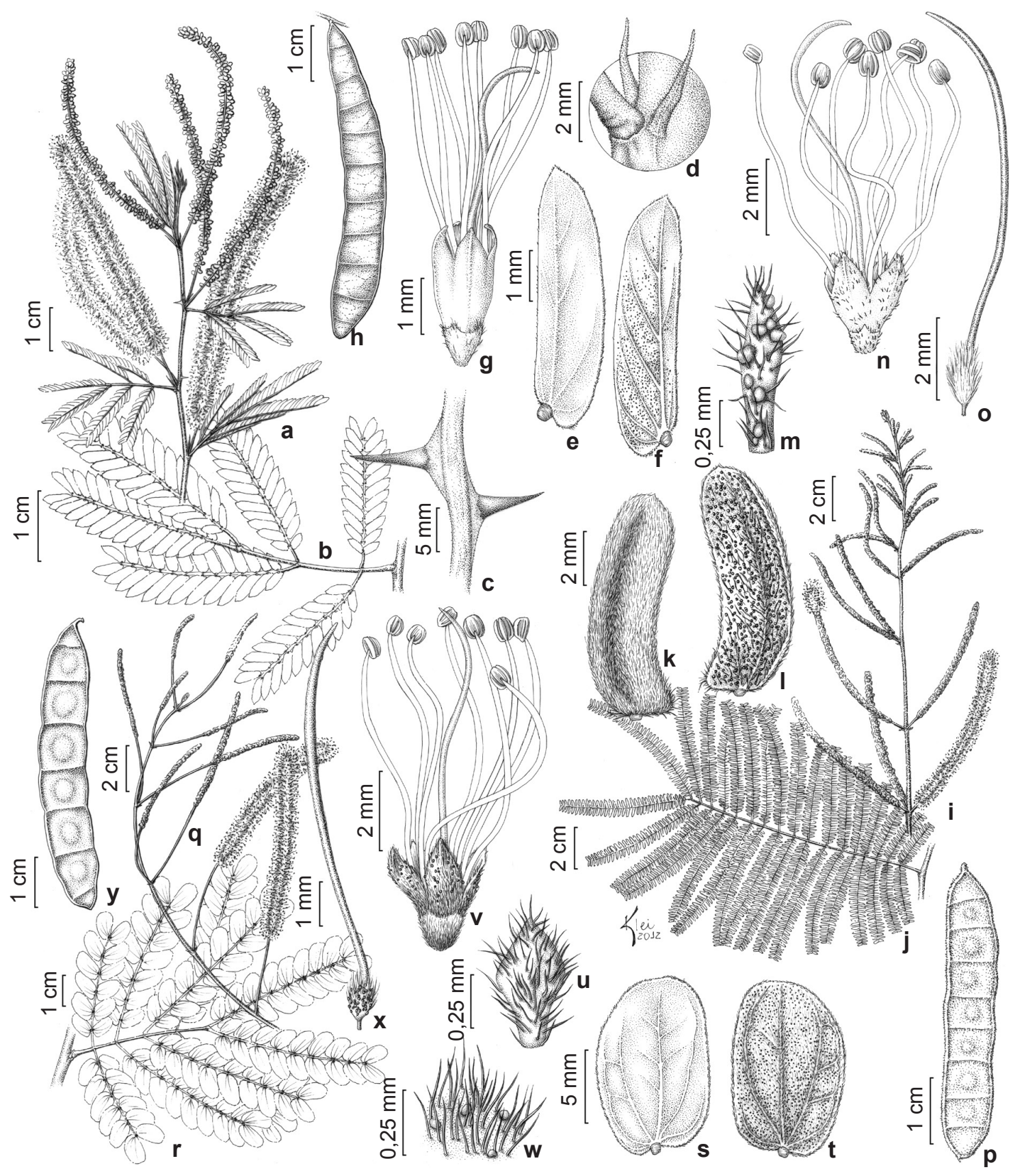

Figura 15 - a-h. Mimosa ophthalmocentra - a. ramo florido; b. folha; c. detalhe dos acúleos; d. detalhe das estípulas; e. foliólulo, face adaxial; f. foliólulo, face abaxial; g. flor; h. fruto. i-p. M. pteridifolia - i. ramo florido; j. folha; k. foliólulo, face adaxial; 1. foliólulo, face abaxial; m. bractéola; n. flor; o. gineceu; p. fruto. (i-o. J.H. Kirkhride Jr. 5234; p. L.P. de Queiroz \& N. S. Nascimento 4550). q-y. Mimosa sericantha-q. ramo florido; r. folha; s. foliólulo, face adaxial; t. foliólulo, face abaxial; u. bractéola; v. flor; w. detalhe do indumento da flor; x. gineceu; y. fruto. (q-x. R.C. Oliveira et al. 1151; y. E. Melo et al. 8303).

Figure 15 - a-h. Mimosa ophthalmocentra - a. flowering branch; b. leaf; c. detail of aculei; d. detail of stipules; e. leaflet, adaxial surface; f. leaflet, abaxial surface; g. flower; h. fruit. i-p. M. pteridifolia - i. flowering branch; j. leaf; k. leaflet, adaxial surface; 1. leaflet, abaxial surface; m. bract; n. flower; o. gynoecium; p. fruit. (i-o. J.H. Kirkhride Jr. 5234; p. L.P. de Queiroz \& N. S. Nascimento 4550). q-y. Mimosa sericantha - q. flowering branch; r. leaf; s. leaflet, adaxial surface; t. leaflet, abaxial surface; u. bract; v. flower; w. detail of flower indumentum; x. gynoecium; y. fruit. (q-x. R.C. Oliveira et al. 1151; y. E. Melo et al. 8303). 
Neg. 54862!, 54863!, K (hb. Hook)!, US (1673885; 702858)!; W).

Mimosa artemisiana Heringer \& Paula, Anais Soc. Bot. Brasil, XXX Congr. Nac. Bot.: 75, Fig. 1. 1979. Tipo: Brasília, DF, Estação Experimental de Biologia da Universidade de Brasília, E.P. Heringer et al. 15506 (Holótipo: IBGE!; Isótipos: K!, NY!, UB!, US!), syn. nov.

Fig. 16

Árvore 8-25 m alt.. Ramos inermes a raramente aculeados, velutinos a lanosos, castanhos. Acúleos internodais, retos, com base larga. Tricomas medusiformes e verruciformes ferrugíneos, distribuídos nos ramos, raque foliar e eixo principal da panícula e das espigas; estrelados sésseis ferrugíneos nas flores e no ovário; estrelados sésseis e verruciformes ferrugíneos entremeados por glândulas sésseis, lentiformes, amareladas a ferrugíneas, na face abaxial dos foliólulos, geralmente ao longo das nervuras primárias e nos frutos; simples esbranquiçados na face adaxial e na margem dos folíolos. Estípulas 3-15 $\times 0,4-1 \mathrm{~mm}$, triangulares ou subuladas, não ciliada-glandulares. Folhas 6-15 pares de folíolos crescentes; pecíolo 1,5-3 cm compr.; raque 6-17,5 $\mathrm{cm}$; espículas ausentes; segmento da raque 0,7-2 cm compr.; foliólulos 18-33 pares, decrescentes proximalmente; ráquila $4-11,5 \mathrm{~cm}$ compr., subcilíndrica; lâmina 5-15 × 2-4 mm, cartácea, oblonga, base auriculada, ápice arredondado a ligeiramente agudo, margem não revoluta, ciliada, concolor, verde, face adaxial glabra a pilosa, face abaxial com tricomas verruciformes esparsos ao longo das nervuras, 2-3-nervada, nervuras mais evidentes na face abaxial sendo uma central ramificada atingindo o ápice. Pedúnculo 1-2 $\mathrm{cm}$ compr.; brácteas ausentes. Espigas 7-10 $\times$ 0,6-0,8 cm, congestas, $2-4$-fasciculadas, reunidas em panículas terminais; inflorescências latentes ausentes; bractéolas persistentes, menores que o botão floral, 1,5 $\times 0,5 \mathrm{~mm}$, oblanceoladas a obtruladas, não ciliada-glandulares. Flores tetrâmeras, bissexuadas ou menos frequentes unissexuadas, sésseis, lanosas; cálice 1-1,3 mm compr., tubuloso, lanoso; corola 2,8-3 mm compr., tubulosa, lanosa, lacínias eretas, convexas; filetes 7-8 mm compr., livres, brancos; ovário 0,8-1 mm compr., séssil, glabro a viloso no ápice; estilete 7-9 mm compr.. Craspédios 5-7 × 0,8-0,9 cm, cartáceos, 4-8-articulados, estipitados, estípite 2-6 mm compr., oblongos, base atenuada, ápice mucronado, tomentosos, castanhos; artículos quadrangulares ou retangulares, elevados na região das sementes; réplum reto a constricto entre os artículos, 0,3-0,5 mm. Sementes 3-5 × 3-5 mm, orbiculares, marrons.

Distribuição geográfica e habitat: Espécie referida para o Brasil, Guiana, Honduras, Nicarágua e Venezuela. No Brasil, ocorre espontaneamente no Acre, Amazonas, Bahia, Espírito Santo, Minas Gerais, Pará, Pernambuco, Rio de Janeiro e Roraima, sendo cultivada ainda no Distrito Federal e em Minas Gerais. Mimosa schomburgkii pode ser encontrada em matas ciliares, no interior e borda de florestas primárias e secundárias, sobre solos argilosos e pedregosos, em altitudes que variam de 110-250 m.

Fenologia: floresce e frutifica praticamente $o$ ano inteiro.

Nome popular: angico-bravo, bracatinga, "carbón" e "sirsir" (Honduras), jurema, monjoleiro, monjolinho.

Mimosa schomburgkii é umas das poucas espécies de porte arbóreo de M. ser. Leiocarpae, podendo ser reconhecida pelos ramos velutinos a lanosos, cujo indumento é constituído por tricomas medusiformes e verruciformes ferrugíneos, folhas com 6-15 pares de folíolos, inflorescências agrupadas em panículas terminais, flores lanosas e filetes brancos. A presença de tricomas estrelados revestindo a face adaxial dos folíolos e flores também auxilia no reconhecimento desta espécie.

Mimosa schomburgkii é facilmente confundida com $M$. trianae. No entanto, esta última espécie pode ser diferenciada pelos foliólulos falciformes, cartáceos, discolores com face adaxial verde-escuro e abaxial esbranquiçada, densamente lanosa, recoberta por tricomas estrelados e tricomas verruciformes esparsos e margem fortemente revoluta. Além disso, esta espécie apresenta distribuição geográfica distinta, ocorrendo apenas na Colômbia.

Barneby (1991) considerou M. schomburgkii distinta de $M$. artemisiana. As principais características usadas por este autor foram: o tamanho da corola (1,7-2,5 mm em M. schomburgkii (vs. 2,8-4,1 mm em M. artemisiana) e do lobo posterior da base auriculada dos foliólulos $(0,4-1,1$ $\mathrm{mm} v s .1-1,7 \mathrm{~mm}$ ). Utilizou também a distribuição geográfica para manter ambas como espécies distintas: $M$. artemisiana seria encontrada apenas na Bahia, Minas Gerais e Rio de Janeiro, possuindo, portanto, uma distribuição mais restrita do que M. schomburgkii que ocorreria no Brasil, Guiana, Honduras, Nicaragua e Venezuela. 
A análise de aproximadamente 100 espécimes de ambas espécies e da observação de uma população de M. schomburgkii em campo demonstrou que a variação no tamanho da corola e da base do foliólulos não são descontínuas e não existe nenhum padrão nas suas dimensões. Além disso, não encontramos nenhum conjunto de características que justificasse a separação destas espécies.

Mimosa artemisiana foi descrita por Heringer \& Paula (1979), após a realização de um estudo anatômico experimental que visava a busca de caracteres anatômicos e morfológicos que auxiliassem na distinção de $M$. schomburgkii e $M$. artemisiana, consideradas muito próximas morfologicamente. Os seguintes resultados dendrólogicos e anatômicos da madeira foram considerados por Heringer \& Paula (1979): diâmetro dos poros (116um em M. artemisana $\times 108 \mu \mathrm{m}$ em M. schomburgkii), frequência dos poros $\left(2,4\right.$ por $\mathrm{mm}^{2}$, M. artemisana $\times 3,4$ por $\mathrm{mm}^{2}$, M. schomburgkii), tipo de placa de perfuração (geralmente simples, M. artemisana $\times$ geralmente multiperfurada, M. schomburgkii), largura dos elementos de vasos $(57 \mu \mathrm{m}$, M. artemisana $\times$ $57 \mu \mathrm{m}$, M. schomburgkii) e o padrão das pontuações intervasculares (guarnecidas $\times$ guarnecidas em ambas as espécies). Tais características nem sempre foram mutuamente exclusivas e muitas delas são discretas. Com base no exposto, estamos propondo a sinonimização de $M$. artemisiana em $M$. schomburgkii.

O epíteto "schomburgkii" foi uma homenagem ao botânico Robert Hermann Schomburgk, um dos primeiros coletores desta espécie.

Material selecionado: BRASIL. ACRE: Rio Branco, 28.VI.1937, fl., A. Ducke 519 (K, NY, R, US). AMAZONAS: Manaus, Fazenda do Igarapé, 24.XII.1941, fl., A. Ducke 1222 (NY, R, RB, US). BAHIA: Vitória da Conquista, BR-263, Vitória da Conquista-Itambé, 25.IV.1998, fl., J.G. Jardim \& H. Lorenzi 1778 (CEPEC, K, MO). DISTRITO FEDERAL: Brasília, Estação experimental da Biologia, campus da Universidade de Brasília, 30.V.1973, fl., E.P. Heringer et al. 12781 (IBGE, MO, RB, UB, US). MINAS GERAIS: Itambacuri, 19.V.1964, Z. A. Trinta \& E. Fromm 703 (HB, SPF, NY, RB). PARÁ: Belém, 23.I.1949, fr., J.M. Pires 1482 (IAC, NY). PERNAMBUCO: São Lourenço da Mata, Estação Ecológica do Tapacurá, K. Almeida 159 (PEUFR). RIO DE JANEIRO: Jardim Botânico, 7.IV.1951, fl., J.J. Kubl s.n. (RB 102190). RORAIMA: Boa Vista, $20 \mathrm{~km}$ da ponte dos Macuxis, 11.II.1977, fl., N.A. Rosa \& M.R. Cordeiro 1434 (INPA, K, NY). GUIANA. Pirara, II.1841, fl., Schomburgk 313 (NY).
HONDURAS. BONITO ORIENTAL: Cohdefor, 18.II.1991, fl., J.J. Helljn \& C.E. Hughes 15 (K, NY); COLON: rd. Bonito Oriental-Limon, 14.II.1991, fl., T.D. Pennington \& P. House 13413 (K, MO, NY); COROCITO: Corocito-Black River, 16.II.1927, fl., S.J. Record \& R.H. Kuylen 73 (NY); GRAÇAS A DIOS: Las Marias: Renare Station, 13.IV.1981, fl., J. Saunders 1071 (NY); MOSQUITA: Gracios-Dios, Rio Platano, 23.III.1973, fl. e fr., A. Gentry, A. Crewell \& G. Cruz 7501 (MO). NICARÁGUA. ZELAYA: Rio Lious, 4.III.1971, fl., E.L. Little Jr. 25056 (MO). VENEZUELA. BOLÍVAR: La Paragua, ao longo do Rio Paragua, 9.IV.1943, fl., E.P. Killip 37265 (K, NY, US). GUÁRICO: ao Norte de Espino, 2.IX.1955, fl., F. Tamayo 4156 (US).

22. Mimosa sericantha Benth. J. Bot. (Hooker) 4: 392. 1841. Tipo: [Brasil], Prov. Pernambuco, Sta. Rosa, distr. of Rio Preto, Gardner n. 2833 (Holótipo: K (hb. Benth.)! = IPA Neg 1278! = NY Neg 1858!; Isótipos, K (hb. Hook)! = IPA Neg 1277!).

Fig. 15q-y

Arbusto a arvoreta 1,5-4 m alt.. Ramos inermes, puberulentos, tomentosos a vilosos, amarronzados a vináceos. Tricomas simples acinzentados, intercalados por glândulas sésseis, lentiformes a globosas, amarelo-translúcidas ou enegrescidas, distribuídos nos ramos, face abaxial dos foliólulos, ovário e frutos. Estípulas $1-7 \times 0,6-1 \mathrm{~mm}$, triangulares a subuladas, não ciliada-glandulares. Folhas $2-5$ pares de folíolos crescentes; pecíolo 0,5-2,5 cm compr.; raque 1-5 $\mathrm{cm}$, interrompida por uma estrutura semelhante a uma ponte; espículas ausentes; segmento da raque 0,9-2,3 cm compr.; foliólulos 4-10 pares, decrescentes proximalmente; ráquila $2,5-10 \mathrm{~cm}$ compr., sulcada a cilíndrica; lâmina 15-45 × 10-45 $\mathrm{mm}$, membranácea a cartácea, oblonga, oboval, oval, suborbicular a orbicular, base redonda, ápice redondo a emaginado, margem não revoluta, ciliada a não ciliada, glabra, puberulenta a tomentosa, 3-5-nervada, nervuras evidentes em ambas as faces, apenas a mais central atinge o ápice. Pedúnculo $0,7-2 \mathrm{~cm}$ compr.; brácteas ausentes. Espigas $6-7 \times$ $0,4-0,5 \mathrm{~cm}$, congestas, solitárias a 2-4-fasciculadas, reunidas em panícula, nas axilas de folhas jovens ou totalmente desenvolvidas ou em ramos desfolhados; inflorescências latentes ausentes; bractéolas persistentes, menores que o botão floral, $0,8-1 \times 0,3-0,4 \mathrm{~mm}$, rômbicas, oblongas a elípticas, côncavas, não ciliada-glandulares. Flores tetrâmeras, bissexuadas, sésseis; cálice 0,9-1 mm compr., tubuloso, tomentoso a seríceo; corola 2,5-3 mm compr., campanulada, lacínias 


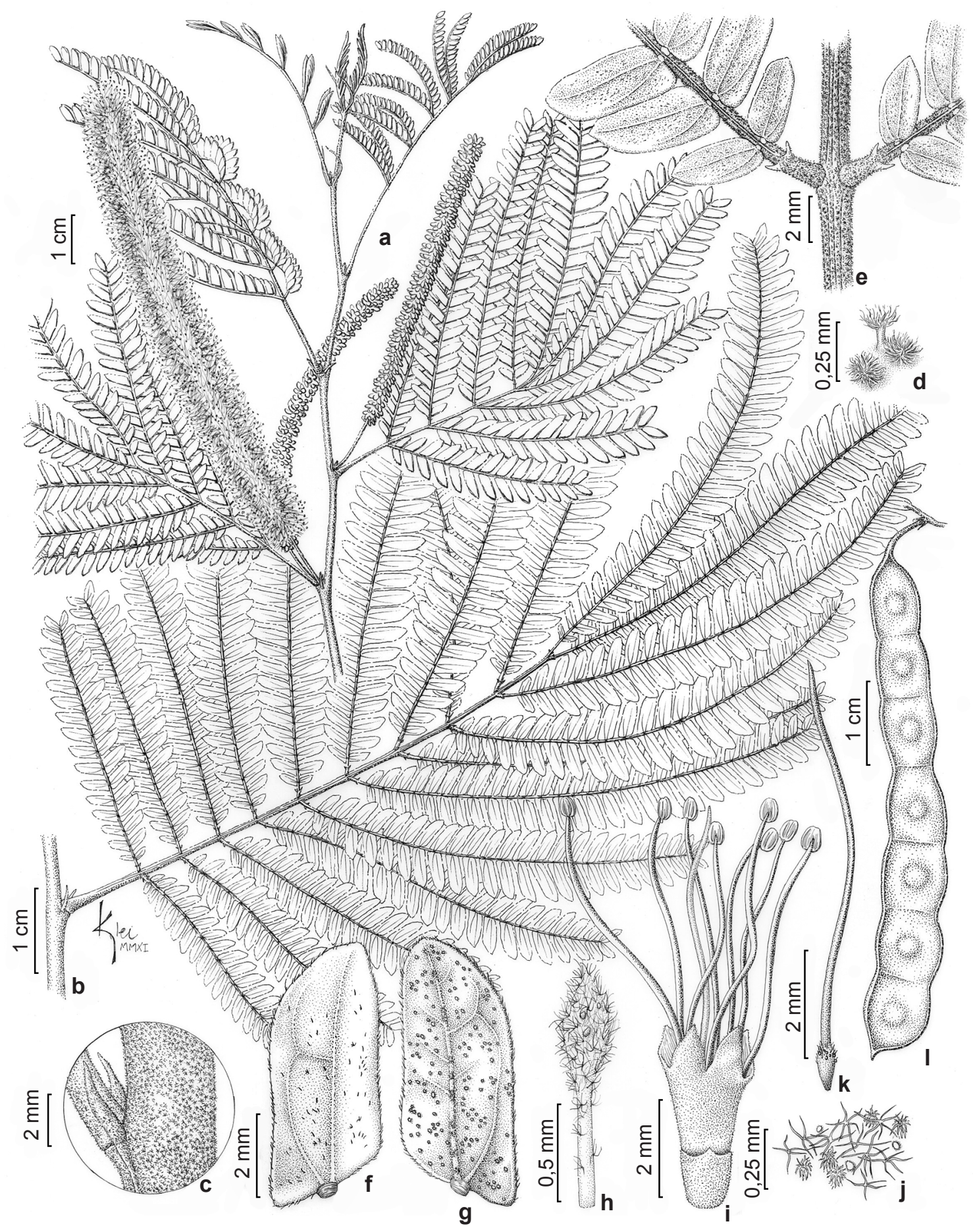

Figura 16 - Mimosa schomburkii - a. ramo florido; b. folha; c. detalhe das estípulas; d. detalhe do indumento; e. detalhe da raque mostrando os parafilídios; f. foliólulos, face adaxial; g. foliólulos, face abaxial; h. bractéola; i. flor; j. detalhe do indumento da flor; k. gineceu; 1. fruto. (a-k. E.P. Heringer 15731; 1. M. Santos \& J.C.A. Lima 145). Figure 16 - Mimosa schomburkii - a. flowering branch; b. leaf; c. detail of stipules; d. detail of indumentum; e. detail of leaf rachis, showing paraphyllidia; f. leaflet, adaxial surface; g. leaflet, abaxial surface; h. bract; i. flower; j. detail of flower indumentum; k. gynoecium; 1. fruit. (a-k. E.P. Heringer 15731; 1. M. Santos \& J.C.A. Lima 145) 
eretas; filetes 8-10 mm compr., livres, róseos; ovário $0,6-0,9 \mathrm{~mm}$ compr., curtamente estipitado (0,2-0,3 mm compr.), velutino a piloso; estilete 6-8 mm compr.. Craspédios 4-6,5 × 0,7-0,9 cm, cartáceos, 5-7-articulados, estipitados, estípite 2-8 $\mathrm{mm}$ compr., oblongos, base arredondada, ápice agudo a mucronado, glabros, castanhos; artículos quadrangulares ou elipsoides, elevados na região das sementes; réplum reto a ligeiramente constricto entre os artículos, 0,3-0,5 mm. Sementes 2,8-3,8 $\times 2,6-3 \mathrm{~mm}$, orbiculares, marrons.

Distribuição geográfica e habitats: Mimosa sericantha distribui-se, predominantemente, nos estados da Bahia e Tocantins, e, mais raramente, em Goiás, Maranhão, Minas Gerais e Piauí. Esta espécie forma densas populações em áreas de cerrado, caatinga e de transição caatinga-cerrado, sobre solo arenoso ou pedregoso, entre 300 e $950 \mathrm{~m}$ de altitude. Na região maranhense cresce também em borda de mata de galeria. No material tipo é citado Pernambuco, Distr. Rio Preto (Gardner 2833), entretanto, nenhuma outra coleta deste táxon, neste estado, foi registrada. Portanto, acreditamos que realmente $M$. sericantha não ocorra neste estado e que essa localidade pertença ao atual município de Rio Preto localizado no estado de Minas Gerais.

Fenologia: floresce de abril a setembro e frutifica em maio, julho e setembro.

Mimosa sericantha é uma das poucas espécies com macrofilídios em $M$. ser. Leiocarpae, podendo ser reconhecida pelas folhas com dois a cinco pares de folíolos, com foliólulos oblongos, obovais ou ovais, variando de 15-45 × 5-45 mm, espigas reunidas geralmente em amplas panículas terminais ou em ramos áfilos e pelas flores velutinas, vilosas a seríceas, cujo indumento é constituídos por tricomas simples acinzentados. Os frutos longo estipitados (até $8 \mathrm{~mm}$ ) é uma outra característica bastante útil para sua identificação.

O epíteto específico "sericantha” (serice=sedoso; antha=flor) se refere ao indumento sedoso que reveste as flores.

Material selecionado: BRASIL. BAHIA: Barreiras, BR-020, próximo ao Rio de Ondas, 9.VI.1980, fl., C.A. Miranda 325 (RB). GOIÁS: Posse, BR-020, $15 \mathrm{Km} \mathrm{S}$ de Posse, 10.III.1079, fl., G. Hatschbach 42029 (MBM, US). MARANHÃO: Balsas, Agrovila Di Carli, 4.VIII.1998, fl., R.C. Oliveira, G.P. da Silva \& M.M.R. Cunha 1151 (HUEFS) MINAS GERAIS: Formoso, Capela de São Francisco, 8.VIII.2000, fl., J.A. Ratter et al. 8300 (K). PIAUÍ: Ribeiro Gonçalves, Estação Ecológica de Urucuí-Una, 4.IX.1991, fl.,
A. Fernandes \& V. Rodrigues s.n. (EAC 10725, NY 936049). TOCANTINS: estrada entre Ponte Alta e Mateiros, 10.V.2012, fl., J.S. Silva \& H. Moreira 1142 (CEN, UEC); estrada para Dianópolis via Guamambi, 10.VI.2012, fl., J.S. Silva \& H. Moreira 1155 (CEN, UEC).

23. Mimosa spixiana Barneby, Mem. New York Bot. Gard. 65: 141-142. 1991, emend. J. SantosSilva \& A.M.G. Azevedo. Tipo: Brasil, Prov. Minas Gerais, in campis Chapada do Paranán, Sept. [1818], K.F.P. von Martius 1814 (Holótipo: $\mathrm{M}=\mathrm{NY}$ Neg. 11545!). $\quad$ Fig. 17

Subarbusto a arbusto 0,8-2 m alt.. Ramos inermes, glabros a puberulentos, castanhos. Tricomas simples esbranquiçados, intercalados por glândulas sésseis, lentiformes esparsas, douradas, distribuídos nos ramos, folhas, face abaxial dos foliólulos, eixo das inflorescências e flores. Estípulas 2-3,2 ×0,4-0,5 mm, lanceoladas a subuladas, não ciliada-glandulares. Folhas 4-9 pares de folíolos crescentes; pecíolo $0,5-4,5 \mathrm{~cm}$ compr.; raque 3-5(-21) cm; espículas ausentes; segmento da raque $1-2 \mathrm{~cm}$ compr.; foliólulos 9-20(-28) pares, crescentes; ráquila $3-5(-9,5)$ cm compr., subcilíndrica; lâmina 5-10 × 2-5 mm, cartácea-coriácea, oblonga, base arredondada a discretamente cordada, ápice arredondado, margem não revoluta, face adaxial sublustrosa, glabra, face abaxial puberulenta, 2-5-nervada, com apenas uma nervura atingindo o ápice. Pedúnculo 0,9-1 cm compr.; brácteas ausentes. Espigas 5,5-6,5(-12) $\times$ 0,4-0,5 cm, congestas, $2-3$-fasciculadas, axilares ou reunidas em panículas terminais nos ramos desfolhadas; inflorescências latentes ausentes; bractéolas persistentes, menores que o botão floral, $1-1,2 \times 0,2-0,3 \mathrm{~mm}$, lanceoladas a obtruladas, não ciliada-glandulares. Flores tetrâmeras, bissexuadas, sésseis; cálice 0,9-1 mm compr., tubuloso, tomentoso a seríceo; corola $2-2,5 \mathrm{~mm}$ compr., campanulada, tomentosa a serícea com glândulas esparsas, lacínias eretas; filetes 7-9 mm compr., livres, róseos; ovário $0,8-1 \mathrm{~mm}$ compr., estipitado ( 2 mm compr.), viloso, com glândulas; estilete 8-9 mm compr.. Craspédios 3-5,5 × 0,9-1 cm, cartáceos, 4-6-articulados, estipitados, estípite 3-8 mm compr., oblongos, base atenuada, ápice ápice agudo, arredondado a aristado, glabros com glândulas, castanhos; artículos compressos, quadrangulares ou retangulares; réplum reto a ligeiramente constricto entre os artículos, 0,4-0,5 $\mathrm{mm}$. Sementes $4-5 \times 4-5 \mathrm{~mm}$, orbiculares, marrons. 
Distribuição geográfica e habitat: Mimosa spixiana ocorre no leste de Tocantins, registrada somente para os municípios de Mateiros e Pindorama. Apesar da coleção-tipo ter sido coletada em Minas Gerais, nenhuma coleta recente deste táxon para este Estado foi encontrada. Ocorre simpatricamente com $M$. sericantha em áreas de campo sujo e cerrado, sobre solo arenoso, em altitudes que variam de $430-530 \mathrm{~m}$.

Fenologia: coletada com flores e frutos em maio e junho.

Mimosa spixiana é caracterizada pelos ramos inermes, presença de glândulas lentiformes, sésseis sobre as estruturas vegetativas e reprodutivas e pelas folhas com quatro a nove pares de folíolos e nove a 28 pares de foliólulos. Os frutos são estipitados, glabros, com glândulas sésseis esparsas.

É comum encontrar espécimes de M. spixiana identificados como $M$. sericantha devido à semelhança morfológica compartilhada por essas espécies. Ambas possuem ramos inermes, espigas reunidas geralmente em amplas panículas terminais, flores indumentadas e frutos compressos, estipitados. Entretanto, os foliólulos de $M$. sericantha opacos e membranáceos a cartáceos (vs. sublustrosos na face adaxial e cartáceo-coriáceos em M. spixiana), maiores $(15-45 \times 10-45 \mathrm{~mm}$ vs. $5-10 \times 2-5 \mathrm{~mm})$ e em menor número por folíolo (4-10 pares vs. 9-28 pares). Além disso, M. sericantha possui distribuição geográfica mais ampla, ocorrendo no estado da Bahia, Goiás, Maranhão, Piauí e Tocantins, em áreas de cerrado, caatinga e de transição caatinga-cerrado.

A primeira observação sobre a proximidade morfológica entre M. spixiana e M. sericantha foi feita por Barneby (1991). Para este autor, os frutos poderiam fornecer indícios mais fortes sobre essa relação. Após análise cuidadosa dos frutos e das demais estruturas, em campo e em laboratório, confirmamos esta proximidade citada por Barneby (1991). Além disso, compartilham o mesmo ambiente em Tocantins, muitas vezes crescendo lado a lado. Ressaltamos que pela primeira vez são registradas informações sobre as características morfológicas dos frutos e sementes de M. spixiana.

Dentre os especimens coletados, o de J.S. Silva \& H. Moreira 1118, proveniente de Mateiros no estado de Tocantins, apresenta algumas características atípicas, como os ramos jovens vináceos ( $v s$. geralmente esverdeados), maior número de pares de folíolos (28 vs. 9-20 pares), raque e ráquila com maior comprimento $(21 \mathrm{~cm}$ vs. 3-5 cm; 9,5 cm vs. 3-5 cm) e inflorescências maiores $(12 \mathrm{~cm} v s .5,5-6,5 \mathrm{~cm})$. No entanto, as demais características são próprias de M. spixiana.

O epíteto específico foi dado em homenagem ao zoólogo Johann Baptist von Spix, companheiro de K.F.P. von Martius durante a sua estadia no Brasil (1817-1820) (Barneby 1991).

Material selecionado: BRASIL. TOCANTINS: Mateiros, estrada entre Ponte Alta e Mateiros, idem, 10.V.2012, fl., J.S. Silva \& H. Moreira 1141 (CEN, UEC); estrada para Dianópolis via Guamambi, 10.VI.2012, fl., J.S. Silva \& H. Moreira 1154 (CEN, UEC); Parque das Dunas, próximo da Serra do Espírito Santo, 10.VI.2012, fl. e fr., J.S. Silva \& H. Moreira 1145 (CEN, UEC); Pindorama do Tocantins, estrada em direção a Ponte Altas, 9.V.2012, fl. e fr., J.S. Silva \& H. Moreira 1118 (CEN, UEC).

24. Mimosa tenuiflora (Willd.) Poir., Encycl. Suppl. 1: 82. 1810. Acacia tenuiflora Willd., Sp. Pl. 4:1088. 1806. Tipo: Habitat ad Caracas, Bredemeyer (Lectótipo: Bredemeyer 20 B-W!, primeiro passo lectótipo designado por Barneby 1991:135, segundo passo lectótipo designado aqui). Acacia hostilis Mart., Reise 1: 555.1823. Tipo: In inundatis Lagadisso ad flumen S. Franciscco inter Salgado et Malhada provinciae Minas Gerais et in Silvis ad Sincora provinciae Bahiensis, Martius s.n. (Holótipo: M-0171190 = F Neg $6185=$ IPA Neg. 1348!).

Mimosa apodocarpa var. hostilis (Mart.) Hassl., Repert. Spec. Nov. Regni Veg. 9:1. 1910, baseado em Acacia hostilis Mart., Reise 1: 555.1823.

Mimosa cabrera H. Karst., Fl. Columb. 2: 63-64, t. 132. 1863. Tipo: Habitat planities calidas siccas septentrionales Columbiae, G.C.W.H. Karsten s.n. (Holótipo: W-0026603, foto!).

Mimosa limana Rizz., Leandra 4-5: 14. 1974. Tipo: Bahia, Vivit in caatinga ad Senhor do Bonfim, 16 May 1973, D.P. Lima 13147 (Holótipo: RB!).

Mimosa nigra Huner, Bull. Herb. Boissier, sér. 2, 1: 303. 1901. Tipo: [Ceará], Dépressions humides dans le Sertão, pres Quixadá, Oct 1987, J. Huber 309 (Holótipo: MG, foto!).

Fig. 18a-k

Subarbusto a arvoreta 2-8 m alt.. Ramos aculeados a raramente inermes, resinosos, glabros a puberulentos, quando jovens nigrescentes. Acúleos internodais, retos, com base larga. Tricomas simples esbranquiçados, intercalados por glândulas sésseis, lentiformes, raramente por glândulas estipitadas (0,3-0,4 mm compr.), amareladas a acobreadas, distribuídos nos ramos, estípulas, pecíolo, raque, raque da inflorescência, cálice, lacínias da corola, 

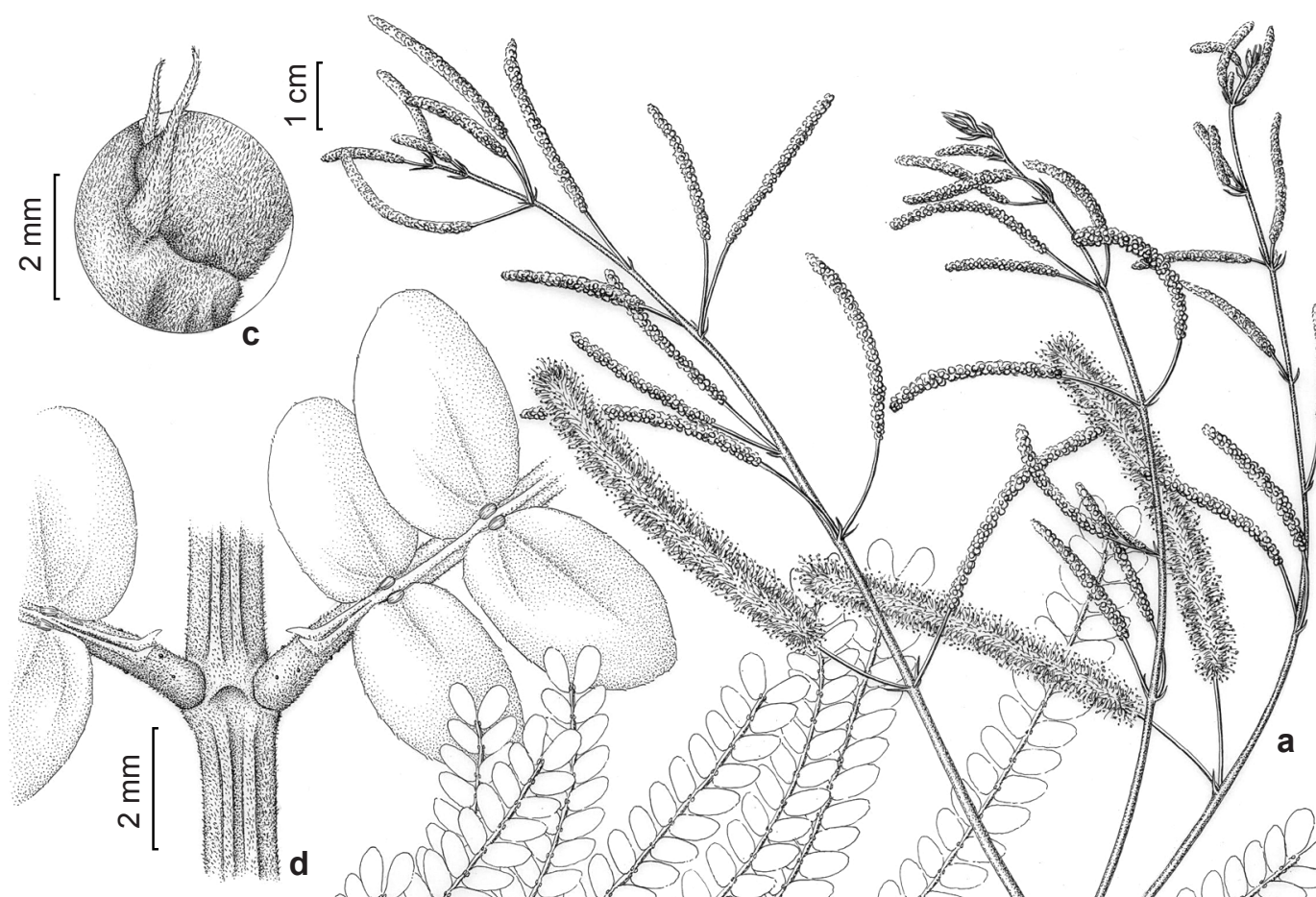
ovário e frutos. Estípulas 1,2-2,4 × 0,5-1 mm, triangulares, não ciliada-glandulares. Folhas 4-10 pares de folíolos discretamente crescentes; pecíolo 0,9-1,7 cm compr., resinoso principalmente nas folhas jovens; raque $1,8-3,5(-4,5) \mathrm{cm}$, interrompida entre cada par de folíolos por espícula; segmento da raque $0,4-0,8 \mathrm{~cm}$ compr.; foliólulos $17-25$ pares, decrescentes proximalmente; ráquila $2,5-4,5(-5)$ cm compr., cilíndrica a subcilíndrica; lâmina 4,5-8 $\times$ 0,6-1,8 mm, cartácea, oblonga, base oblíqua, ápice arredondado a mucronulado, margem não revoluta, discretamente ciliada a não ciliada, glabra a puberulenta, face abaxial com pontuações glandulares, 1-2-nervada, nervuras mais evidentes na face abaxial, quando em número de duas, uma delas pouco evidente e não atinge o ápice. Pedúnculo 0,3-0,4 cm compr.; brácteas ausentes. Espigas 6,5-10,5 × 0,4-0,5 cm, laxifloras, solitárias a 2-fasciculadas, nas axilas de folhas jovens ou totalmente desenvolvidas; inflorescências latentes simultaneamente com as espigas expandidas ou até mesmo com infrutescências; bractéolas persistentes, menores que o botão floral, $0,6-1,3 \times$ 0,4-0,6 mm, oblanceoladas a obtruladas, côncavas, não ciliada-glandulares. Flores tetrâmeras, bissexuadas, sésseis; cálice 0,9-1,2 mm compr., tubuloso, 4-angulado por nervura proeminente e incurvada, puberulento; corola 2,8-3 mm compr., campanulada, glabra, lacínias eretas a ligeiramente reflexas; filetes 5-8 mm compr., livres, brancos; ovário $0,8-1 \mathrm{~mm}$ compr., curtamente estipitado (0,2-0,3 mm compr.), viloso com glândulas; estilete 7-9 mm compr.. Craspédios 3,5-4 × 0,6-0,9 cm, cartáceos, 3-5-articulados, estipitados, estípite 0,2-0,5 mm compr., oblongos, base atenuada, ápice mucronado, puberulentos a glabros, castanhos; artículos quadrangulares ou retangulares, inflados na região das sementes; réplum reto a ligeiramente constricto entre os artículos, 0,3-0,4 mm. Sementes 2,8-3,8 × 2,6-3 mm, orbiculares, marrons.

Distribuição geográfica e habitat: Trata-se da espécie mais amplamente distrbuída de $M$. ser. Leiocarpae s.l.. Ocorre frequentemente em regiões caracterizadas por secas periódicas distribuindose no Brasil, El Salvador, Honduras, México e Venezuela, onde forma densas populações. É citada também para a Colômbia (Barneby 1991). No Brasil, ocorre em toda região Nordeste estendendose até o estado de Minas Gerais, sendo cultivada ainda no Pará.

Fenologia: floresce e frutifica praticamente o ano inteiro.
Nome popular: carbón-colorado (E1 Salvador), carbón (Honduras), jurema, juremapreta (Brasil) e tepescohuite (México).

Mimosa tenuiflora distingue-se das demais espécies, especialmente, por possuir cálice 4-angulado e pelas inflorescências latentes simultaneamente com as espigas em plena floração. As inflorescências latentes provavelmente continuam o seu desenvolvimento no início da estação chuvosa, o que confere à $M$. tenuiflora uma vantagem reprodutiva em relação as demais espécies que ainda precisarão desenvolver as suas flores. A morfologia dos seus frutos também pode auxiliar na sua identificação, pelos artículos inflados na região das sementes, caráter não compartilhado por nenhuma outra espécie de $M$. ser. Leiocarpae s.l. Em campo, pode ser reconhecida pelos ramos e folhas novas resinosos. Nas populações do Nordeste são geralmente encontradas galhas distribuídas ao longo dos ramos.

Foram observadas glândulas estipitadas revestindo densamente os ramos e folhas de vários indivíduos coletados no México e em Honduras. No entanto, estas glândulas não estão restritas às populações mexicanas e hondurenhas e foram constatadas, com uma menor frequência, em indivíduos do nordeste brasileiro. Acreditamos que, nesta espécie, esta característica seja fortemente influenciada pelo habitat e pelas condições de crescimento dos indivíduos.

Mimosa tenuiflora apresenta múltiplas utilidades já sendo conhecidas suas potencialidades como alucinógena, madeireira, para a produção de lenha, carvão e estacas, forrageira, medicinal de uso popular e, ainda, tem seu tanino extraído pelas indústrias (Carmargo-Ricalde 2000). Do ponto de vista ecológico, $M$. tenuiflora é tipicamente oportunista de rápido crescimento, sendo dessa forma uma boa candidata para o reflorestamento de áreas degradadas.

O basiônimo de Mimosa tenuiflora, Acacia tenuiflora, foi descrito por Willdenow (1806) baseado no espécime "Habitat ad Caracas, Bredemeyer", que é um sintipo. Assim, considerase que o primeiro passo da lectotificação foi feita por Barneby (1991:135) quando ele cita como holótipo o espécime Bredemeyer 20 depositado no herbário B e a mesma coleção citada por Barneby é aqui designada como segundo passo da lectotipificação.

Material selecionado: BRASIL. ALAGOAS: Pão de açúcar, 22.VI.2002, fl., R.P. Lyra-Lemos, S. Souza \& 
J. Sousa 6846 (ESA, HUEFS, MAC). BAHIA: Bom Jesus da Lapa, 18.IV.1980, fl., R.M Harley 21519 (UEC, US). CEARÁ: Aiuaba, Estação Ecológica de Aiuaba, 5.IX.1996, fr., M.I. Bezerra-Loiola 218 (EAC, HUEFS). MARANHÃO: Lorêto, 7.IV.1992, fl., G. Eiten \& L.T. Eiten $4138 b$ (SP). MINAS GERAIS: Itaobim, BR-116, 25.IX.1999, fl. e fr., S.M. de Faria 1798 (RB). PARÁ: Belém, sede da EMBRAPA, Horto de Plantas Medicinais, 28.V.2007, fl. e fr., L.P. de Queiroz et al. 13065 (HUEFS). PARAÍBA: Riacho Gangorra, 11.X.2005, fr., A.V. Lacerda \& F.M. Barbosa 526 (JPB, HUEFS). PERNAMBUCO: Petrolina, Sítio Lajedo, 5.II.2010, fl. e fr., J.S. Silva \& J.E.A. Castro 839 (UEC). PIAUÍ: Dirceu Arcoverde, ca $3 \mathrm{Km}$ da saída, 4.VII.2000, fl., M.M. da Silva et al. 455 (HUEFS). RIO GRANDE DO NORTE: Serra Negra do Norte, Estação Ecológica do Seridó, 15.VIII.2003, fr., M.F. Simon et al. 543 (HUEFS). SERGIPE: Canindé do São Francisco, 27.X.2000, fr., D.M. Coelho \& R. Cardoso 488 (RB). COLÔMBIA. GUAJIRA: $13.7 \mathrm{Km}$. de Riohacha, rumbo a Manaure, 13.IV.1962, fl. e fr., C. Saravia T. \& D. Jonson 524 (US). EL SALVADOR. MORAZAN: desvío a San Carlos, San Francisco Gotera, 23.IV.1989, fl. e fr., M.L. Reyna 1434 (K). MÉXICO. CHIAPAS: $15 \mathrm{Km} \mathrm{W}$ of Villa Flores on the road towards Santa Isabel, 12.II.1985, fl. e fr., C.E. Hughes 522 (K). VENEZUELA. ANZOATEGUI: Cantaura, 19.IV.1950, fl. e fr., F.D. Smith 142 (US).

25. Mimosa trianae Benth., Trans. Linn. Soc. London 30: 412. 1875. Tipo: New Granada [Colombia], Villavicencio, J. Triana s.n. (Lectótipo: K-000532759 [hb. Benth.]!, primeiro passo lectótipo designado por Barneby 1991: $159=\mathrm{NY}$ Neg. 1929!, segundo passo lectótipo designado aqui; Isolectótipo: P, W, COL [J.J. Triana 6834/6] foto!).

Fig. 181-s

Árvore 5-16 $\mathrm{m}$ alt.. Ramos inermes, tomentoso-lanosos, castanhos. Tricomas simples esparsos, tricomas estrelados na face adaxial dos foliólulos, medusiformes e verruciformes ferrugíneos, distribuídos nos ramos, raque foliar, eixo principal da panícula, raque das espigas e frutos; estrelados sésseis, esbranquiçados a amarelados entremeados por glândulas sésseis, pateliformes, douradas na face abaxial dos foliólulos; estrelados sésseis no cálice, corola e ovário. Estípulas 4-10 × 0,2-0,3 mm, lanceoladas a subuladas, não ciliada-glandulares. Folhas 11-17 pares de folíolos crescentes; pecíolo 1-2,3 cm compr.; raque 9,5-13,5 cm; espículas ausentes; segmento da raque $0,7-1 \mathrm{~cm}$ compr.; foliólulos 24-40 pares, decrescentes proximalmente; ráquila 5-13 cm compr., sulcada; lâmina 4-5 × 1-2 mm, cartácea-coriácea, oblonga, base truncada, ápice agudo, margem fortemente revoluta, não ciliada, discolor, face adaxial verde-escuro, puberulenta a pilosa, face abaxial esbranquiçada, lanosa, 2-nervada, sendo uma nervura central ramificada atingindo o ápice. Pedúnculo 2-3 $\mathrm{mm}$ compr.; brácteas ausentes. Espigas 7,5-8,5 × 0,4-0,5 $\mathrm{cm}$, congestas, solitárias ou 2-3- fasciculadas, reunidas em ramos desfolhados; inflorescências latentes ausentes; bractéolas persistentes, menores que o botão floral, $1,5 \times 0,5 \mathrm{~mm}$, oblanceoladas a obtruladas, não ciliada-glandulares. Flores tetrâmeras, bissexuadas, sésseis; cálice 1-1,3 mm compr., tubuloso, lanoso; corola $2-2,3 \mathrm{~mm}$ compr., tubulosa, lanosa, lacínias eretas, convexas; filetes 3-4 mm compr., livres, brancos; ovário 0,9-1 mm compr., séssil, glabro a glabrescente; estilete 4-5 mm compr.. Craspédios 3-5 × 0,8-0,9 cm, cartáceos, 5-6-articulados, sésseis, oblongos, base atenuada, ápice agudo a arredondado, tomentosos a lanosos, castanhos; artículos quadrangulares ou retangulares, compressos; réplum reto a ligeiramente constricto entre os artículos, ca. 0,5 $\mathrm{mm}$. Sementes não observadas.

Distribuição geográfica e habitat: espécie endêmica da Colômbia, $M$. trianae ocorre apenas nos departamentos de Meta e Cundinamarca, localizados na região central, onde cresce em altitudes que variam de 600 a $1400 \mathrm{~m}$.

Fenologia: flores e frutos foram observados em janeiro.

Nome popular: yopo

Mimosa trianae é facilmente reconhecida por ser a única espécie da $M$. ser. Leiocarpae que possui foliólulos cartáceo-coriáceos, discolores, com a face adaxial verde-escuro, puberulenta a pilosa e abaxial esbranquiçada, lanosa.

A espécie mais próxima morfologicamente é M. schomburgkii, com a qual compartilha o hábito arbóreo, a presença de tricomas ramificados (verruciformes, estrelados e medusiformes) nas estruturas vegetativas e reprodutivas, flores com cálice e corola lanosas e frutos castanhos. No entanto, em M. trianae os foliólulos são oblongos, concolores, com a margem não revoluta e a face abaxial com tricomas verruciformes esparsos ao longo das nervuras. Além disso, em $M$. schomburgkii é possível visualizar a epiderme foliar em ambas as faces, enquanto em $M$. trianae isto não é possível devido ao adensamento dos tricomas estrelados sobre a face abaxial.

No protólogo o material tipo foi citado da seguinte maneira: New Granada, Villavicencio, $J$. Triana, sem número de coleta e sem informação 
do herbário em que o holótipo foi depositado, sendo este espécime um síntipo. Barneby (1991) considerou o espécime depositado em K o possível holótipo de M. trianae. Concordamos com ele, pelo fato de Bentham ter trabalhado nesta instituição e por estar depositada neste herbário a maior parte das coleções analisadas por ele. A escolha de Barneby é considerada o primeiro passo da lectotipificação, enquanto o segundo passo é o aqui designado.

O espécime $J$. Triana 6834 , citado por Barneby (1991) como provável isótipo, não foi aqui considerado como tal, por esta numeração estar relacionada a outras oito coleções distintas pertencentes aos gêneros Acaciella Britton \& Rose, Albizia Durazz., Mimosa e Senegalia Raf. (E. Forrero com. pess., 2011). No entanto, observamos que dentre estes materiais a coleta $J$. Triana 6834-6 corresponde realmente a $M$. trianae. Assim esta coleção está aqui sendo designada como isolectótipo.

O epíteto específico foi dado em homenagem ao botânico José Jéronimo Triana, quem coletou pela primeira vez esta espécie.

Material examinado: COLÔMBIA.CUNDINAMARCA: Quetame, carretera a Villavicencio en Monteredondo, 25.I.1968, fl., H. García-Barriga, G. Stout \& R. Jaramillo M. 18938 (COL, K, US). META: vicinity of Villavicencio, 2.I.1945, fl. e fr., D.O. Allen 3326 (MO, US).

26. Mimosa urandiensis J. Santos-Silva, M.F. Simon \& A.M.G. Azevedo, Syst. Bot. 38 (1): 127-131. 2013. Tipo: Bahia, Urandi, rod. BR 122, próximo a divisa com Ouro Branco [Pindaí], $4 \mathrm{Abr}$ 1992, G. Hatschbach 56540 (Holótipo: MBM!; Isótipos: CEPEC, F! NY!).

Arvoreta de estatura desconhecida. Ramos aculeados, tomentosos, castanhos. Acúleos internodais, curvados, com base larga, estendendose ou não para a raque foliar. Tricomas capitadoglandulares, intercalados por tricomas simples esbranquiçados, distribuídos nos ramos, eixo foliar, ráquila, eixo da inflorescência, brácteas, bractéolas e cálice. Estípulas 3-5 × 0,3-1 mm, lineares a lanceoladas, ciliada-glandulares. Folhas 5-9 pares de folíolos crescentes; pecíolo 1,5-3,5 cm compr.; raque $5-10 \mathrm{~cm}$, interrompida entre cada par de folíolos por espícula; segmento da raque 0,9-1 cm compr.; foliólulos 20-23 pares, decrescentes proximadamente; ráquila $3-4 \mathrm{~cm}$ compr., cilíndrica; lâmina 4-5 × 1-1,8 mm, membranácea, oblonga, base oblíqua a ligeiramente truncada, ápice agudo, margem não revoluta, ciliada a não ciliada, discolor, glabra, face adaxial verde-escuro, face abaxial verde-oliva, sem pontuações glandulares ou glândulas sésseis, 1-2-nervada, nervuras mais evidentes na face abaxial, quando em número de dois, uma não atingem o ápice. Pedúnculo 1-1,5 cm compr.; brácteas ausentes. Espigas 3-3,5 $\times$ 0,4-0,5 cm, congestas, 2-3-fasciculadas, nas axilas de folhas jovens ou totalmente desenvolvidas e em ramos desfolhados; inflorescências latentes ausentes; bractéolas persistentes, menores que o botão floral, 1,4-2 × 0,3-0,4 mm, oblanceoladas ou elípticas, ciliada-glandulares. Flores tetrâmeras, bissexuadas, sésseis; cálice 1-1,3 mm compr., campanulado, ciliado-glandular, glabro a piloso na base; corola 2-3,4 mm compr., campanulada, glabra, lacínias eretas; filetes $8-9 \mathrm{~mm}$ compr., livres, brancos; ovário 0,7-1 mm compr., estipitado, estípite 6-8 $\mathrm{mm}$, seríceo; estilete 7-8 $\mathrm{mm}$ compr.. Craspédios não observados.

Distribuição geográfica e habitat: Até o momento, Mimosa urandiensis é conhecida apenas da localidade-tipo, no município de Urandi, localizado na divisa entre os estados da Bahia e Minas Gerais. A espécie foi coletada em caatinga, onde foi encontrada crescendo em áreas pertubadas ao longo da margem da rodovia.

Fenologia: Floresce em abril.

Mimosa urandiensis é facilmente reconhecida pela presença de tricomas capitado-glandulares, que conferem um aspecto viscoso aos seus ramos, eixos foliares, raque das inflorescências, ráquila e cálice, associada às estípulas e bractéolas ciliadaglandulares. Outra característica que pode auxiliar na identificação desta espécie é o fato dos acúleos, presentes nos ramos, poderem ocorrer também na eixo foliar e na ráquila, característica pouco frequente em $M$. ser. Leiocarpae.

O espécime G. Hatschbach 56540 (MBM) foi identificado por Barneby (in sched.) como $M$. arenosa var. arenosa e a duplicata, depositada no F, como M. acutistipula por Fortunato (in sched.). Entretanto, uma análise detalhada de aproximadamente 200 espécimes de ambos os táxons e da observação de suas populações em campo permitiu concluir que esta coleção tratavase de uma nova espécie (Santos-Silva et al. 2013). Mimosa urandiensis difere de M. acutistipula e M. arenosa principalmente pelos tricomas capitadoglandulares densamente distribuídos nas estruturas vegetativas e reprodutivas, pela ausência de nervuras nas estípulas (vs. comumente 1-nervada), pecíolo com 1,5-3,5 cm compr. (vs. 0,6-1,5 cm 
compr.), bractéolas e estípulas ciliada-glandulares (vs. não ciliada-glandulares) e ovário seríceo (vs. glabro em $M$. acutistipula e glabro a puberulento em $M$. arenosa).

O epíteto específico faz referência ao município de Urandi, localidade onde a essa nova espécie é endêmica.

27. Mimosa verrucosa Benth., J. Bot. (Hooker) 4: 390. 1841. Tipo: Oeiras, Prov. Piauhy, Gardner 2136 (Lectótipo: K!, designado por Barneby [1991: 153] = IPA Neg. 1270); Isolectótipos: BM!, G, GH, foto HUEFS!, NY!, P, US!, W). Fig. 18t-a'

Arbusto 1,5-4 m alt.. Ramos inermes, verrucosos, castanhos. Tricomas simples esbranquiçados, intercalados por tricomas verruciformes, castanhos e glândulas sésseis a curto-estipitadas ( \pm 0,2 mm compr.), lentiformes, amareladas a acobreadas distribuídos nos ramos, pecíolo, raque, face abaxial dos foliólulos, geralmente ao longo das nervuras primárias, eixo das inflorescências e frutos, tricomas estrelados e simples nas flores e ovário. Estípulas $5-10 \times 0,4-1 \mathrm{~mm}$, lanceoladas a subuladas, não ciliada-glandulares. Folhas 6-10 pares de folíolos crescentes; pecíolo 0,8-3 cm compr.; raque $2,5-7 \mathrm{~cm}$, interrompida entre cada par de folíolos por espícula; segmento da raque $0,7-1,5$ cm compr.; foliólulos 13-26 pares, decrescentes proximalmente; ráquila $1,8-7 \mathrm{~cm}$ compr., sulcada; lâmina 5-10 × 1,6-5 mm, cartácea, oblonga a ligeiramente elíptica, base arredondada, ápice arredondado a agudo, margem não revoluta, não ciliada, discolor, face adaxial verde-escuro, puberulenta a tomentosa, face abaxial verdeoliva, puberulenta a tomentosa com tricomas verruciformes esparsos comumente sobre as nervuras e margem, 2-3-nervada, nervuras mais evidentes na face abaxial, quando em número de três, uma ou duas não atingem o ápice. Pedúnculo 1-2 cm compr.; brácteas ausentes. Espigas 6-13 × 0,4$0,5 \mathrm{~cm}$, congestas, solitárias a 3 - fasciculadas, nas axilas de folhas jovens ou totalmente desenvolvidas e em ramos desfolhados; inflorescências latentes ausentes; bractéolas persistentes, menores que o botão floral, 0,9-1,3 × 0,2-0,3 mm, oblanceoladas, não ciliada-glandulares. Flores tetrâmeras, bissexuadas, sésseis; cálice 0,9-1,3 mm compr., tubuloso, puberulento; corola $2-3 \mathrm{~mm}$ compr., tubulosa, lanosa, lacínias eretas; filetes 7-9 mm compr., livres, róseos; ovário 0,8-1 mm compr., séssil, seríceo comumente no ápice; estilete 7-8 mm compr.. Craspédios 3,5-6,5 × 0,7-0,8 cm, cartáceos, 5-8-articulados, sésseis, oblongos, base atenuada, ápice mucronado, revestidos por tricomas verruciformes, marrons; artículos quadrangulares ou retangulares, compressos; réplum ligeiramente a fortemente constricto entre os artículos, 0,3-0,4 $\mathrm{mm}$. Sementes 4-5 × 4-5 $\mathrm{mm}$, orbiculares a ovoides, marrons.

Distribuição geográfica e habitat: Mimosa verrucosa é comumente encontrada em vegetação de caatinga, cerrado, cerradão e de transição caatinga-cerrado, nos estados da Bahia, Ceará, Goiás (leste), Maranhão, Pernambuco e Piauí, sobre solos arenosos ou argilosos, em altitudes que variam de 239 a $820 \mathrm{~m}$, sendo ainda cultivada no Rio de Janeiro. Em Goiás é conhecida por apenas uma única coleta (G. Davidse \& W.G. D'Arcy 11655 (MO, SP).

Fenologia: floresce e frutifica concomitantemente de julho a fervereiro.

Nome popular: jequirí-liso, jurema, juremapreta, jureminha.

Esta espécie é caracterizada pela presença de tricomas verruciformes, que conferem um aspecto verrucoso aos seus ramos, eixos foliares, raque das inflorescências, face abaxial dos folíolos e frutos. Tricomas estrelados também são observados em $M$. verrucosa e revestem as suas flores. Na corola, estes ocorrem do ápice até a altura do cálice. Barneby (1991) citou a ocorrência de tricomas estrelados apenas no ápice da corola, no entanto esta característica não foi observada em nenhum dos materiais examinados. Os ramos inermes, a folhagem acinzentada, os filetes róseos e o ovário seríceo também auxiliam na caracterização desta espécie.

Pode ser confundida com M. schomburgkii devido principalmente ao indumento lanoso da corola e a presença dos tricomas verruciformes sobre os ramos, eixo foliar, raque das espigas e frutos. No entanto, diferencia-se por ser um arbusto a arvoreta com até $4 \mathrm{~m}$ de altura ( $v s$. árvore de até $25 \mathrm{~m}$ em M. schomburgkii), com 6-10 pares folíolos (vs. 6-15), espigas desenvolvendo-se nas axilas de folhas jovens ou totalmente desenvolvidas e em ramos desfolhados ( $v s$. panículas terminais) e filetes róseos ( $v s$. brancos).

Do latim, verrucosa (verruc) refere-se ao aspecto verrucoso das estruturas vegetativas e reprodutivas devido a presença de tricomas verruciformes.

Material selecionado: BRASIL. BAHIA: Xique-Xique, 01.VI.1991, fl. e fr., H.S. Brito \& T. Pennigton 314 (CEPEC, 


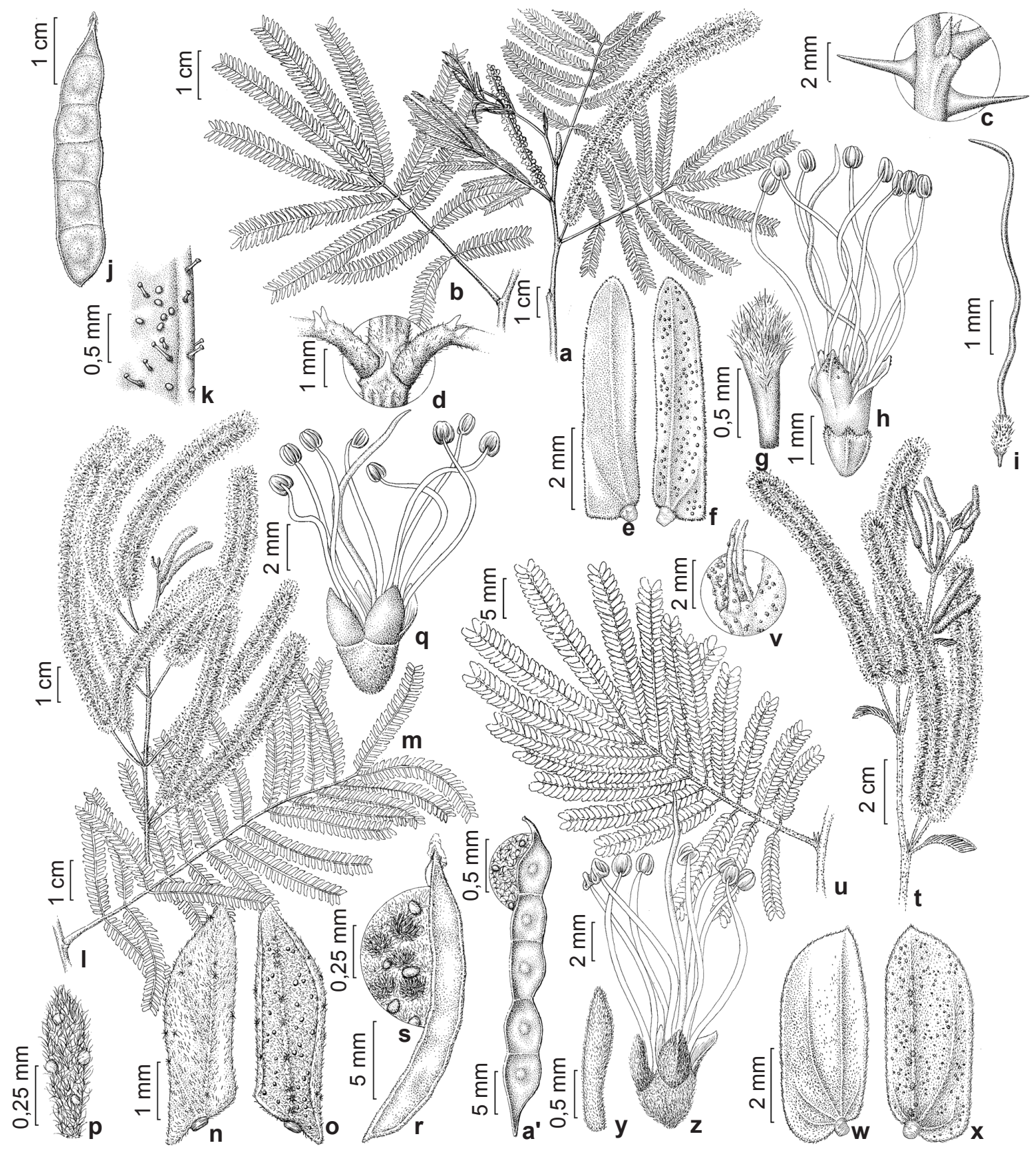

Figura 18 - a-k. Mimosa tenuiflora - a. ramo florido; b. folha; c. detalhe da estípula e dos acúleos; d. detalhe da raque foliar mostrando a espícula e os parafilídios; e. foliólulo, face adaxial; f. foliólulo, face abaxial; g. bractéola; h. flor; i. gineceu; j. fruto. k. Detalhe do indumento do fruto. (a-i. R.M. Harley 21416; j-k. R.M. Harley 18971). 1-s. M. trianae - 1. ramo florido; m. folha; n. foliólulo, face adaxial; o. foliólulo, face abaxial; p. bractéola; q. flor; r. fruto; s. detalhe do indumento do fruto. (D.O. Allen 3326). t-a'. M. verrucosa - t. ramo florido; u. folha; v. detalhe das estípulas; w. foliólulo, face adaxial; x. foliólulo, face abaxial; y. bractéola; z. flor; a'. fruto. (t-z. J.S. Silva \& J.E.A. Castro 827; a'. N. Roque et al. 540).

Figure 18 - a-k. Mimosa tenuiflora - a. flowering branch; b. leaf; c. detail of stipules and aculei; d. detail of leaf rachis, showing spicule and paraphyllidia; e. leaflet, adaxial surface; f. leaflet, abaxial surface; g. bract; h. flower; i. gynoecium; j. fruit. k. detail of fruit indumentum. (a-i. R.M. Harley 21416; j-k. R.M. Harley 18971). 1-s. M. trianae - l. flowering branch; m. leaf; n. leaflet, adaxial surface; o. leaflet, abaxial surface; p. bract; q. flower; r. fruit; s. detail of fruit indumentum. (D.O. Allen 3326). t-a'. M. verrucosa-t. flowering branch; u. leaf; v. detail of stipules; w. leaflet, adaxial surface; x. leaflet, abaxial surface; y. bract; z. flower; a'. fruit. (t-z. J.S. Silva \& J.E.A. Castro 827; a'. N. Roque et al. 540). 
K, NY). CEARÁ: Cratéus, Tucuns, 28.VI.2005, fl., J.R. Lemos \& A.F.R. Sousa 327 (HUEFS). GOIÁS: 16 Km SW de Goiás-Bahia, 8.IV.1976, fl., G. Davidse et al. 12184 (SP). MARANHÃO: Lorêto, Ilha de Balsas, 7.IV.1962, fl., G. Eiten \& L.T. Eiten 4138B (K, NY). MINAS GERAIS: Belo Oriente, 6.VI.2001, fl., G.E. Valente et al. 841 (UEC). PERNAMBUCO: Petrolina, estrada da Tapera, 3.II.2010, fl. e fr., J.S. Silva \& J.E.A. Castro 827 (UEC). PIAUÍ: Castelo do Piauí, 19.IV.1994, fl., M.S. Bona Nascimento 201 (HUEFS, K, MO). RIO DE JANEIRO: Rio de Janeiro, XII.1878, fl., A. Glaziou 9775 (K).

\section{Táxon pouco conhecido}

Mimosa puberula Benth., London J. Bot. 5: 88. 1846. Tipo: México, Zimapan [Zimapán, Hidalgo] Coulter s.n. (Holótipo: K-000082488 (hb. Benth.)! = K Neg. 16895).

Mimosa puberula é uma espécie conhecida apenas pelo holótipo, que consiste em um pequeno fragmento de ramo florido, sem informações sobre a localidade e data de coleta. No entanto, Barneby (1991) acreditou que Coulter tenha coletado esta espécie no Vale Moctezuma (Hidalgo). Segundo Rosaura Grether (com. pess., 2011), nenhum novo registro desta espécie foi encontrado deste então, mesmo após terem sido realizados levantamentos florísticos recentes em regiões próximas. Segundo Barneby (1991), Mimosa puberula difere de todas as espécies simpátricas com espigas, incluindo $M$. tenuiflora, pela presença de glândulas sobre a face abaxial dos folíolos, flores tetrâmeras e pentâmeras na mesma inflorescência e pelo ovário piloso, cujo indumento é constituído apenas por tricomas simples. O posicionamento de $M$. puberula na série Leiocarpae foi considerado duvidoso por Barneby (1991), que qualificou como provisória a posição de $M$. puberula, entre as espécies deste grupo. Estas características podem ser encontradas em outras espécies da série Leiocarpae e dessa forma não são suficientes para circunscrever esta espécie. A decisão sobre a identidade de M. puberula, se como uma espécie distinta ou como um sinônimo de outra, ficará pendente até que tenhamos mais subsídios para elucidar esta situação.

Do latim, puberula (puber = pêlos que aparecem na puberdade; $u l=$ diminutivo) refere-se aos tricomas diminutos que revestem as estruturas vegetativas e reprodutivas.

\section{Agradecimentos}

Agradecemos aos curadores dos herbários visitados, a disponibilidade; a Klei Souza, as ilustrações; a Ângela Sartori, Henrique Moreira e Maria Carolina Abreu, o apoio nas coletas realizadas em Mato Grosso do Sul, Tocantins e Piauí, respectivamente. Este trabalho é parte da tese de Doutorado da primeira autora, no Programa de Pós-graduação em Biologia Vegetal da Universidade Estadual de Campinas (UNICAMP), apoiada pela Fundação de Amparo à Pesquisa do Estado de São Paulo (2009/51593-6) e Rupert C. Barneby Award (2010) do The New York Botanical Garden.

\section{Referências}

Barneby, R.C. 1984. A new Bolivian Mimosa of section Habbasia ser. Leptostachyae (LeguminosaeMimosoideae), close kin of the fictitious genus Schranckiastrum. Brittonia 36: 248-251.

Barneby, R.C. 1985. The genus Mimosa (Mimosaceae) in Bahia, Brazil: New taxa and Nomenclatural adjustments. Brittonia 37: 125-153.

Barneby, R.C. 1991. Sensitivae Censitae. A description of the genus Mimosa L. (Mimosaceae) in the New World. Memories of the New York Botanical Garden 65:1-835.

Bentham, G. 1841. Notes on Mimoseae, with a short synopsis of species. Journal of Botany 4: 243-392.

Bentham, G. 1842. Notes on Mimoseae, with a short synopsis of species. Journal of Botany 4: 393-418.

Bentham, G. 1846. Mimosa. In: Bentham, G. (ed.). Notes on Mimoseae. Journal of Botany 5: 84-93.

Bentham, G. 1875. Revision of the suborder Mimoseae. Transactions of the Linnean Society of London 30: 335-664.

Bentham, G. 1876. Leguminosae-Mimosoideae. In: Martius, C.F.P. Flora Brasiliensis. Ed. Regia C. Wolf et Fil., B.Keller, Monachii. Vol. 15, pt. 2, pp. 456-458.

Bessega, C.; Hopp, H.E. \& Fortunato, R.H. 2008. Toward a phylogeny of Mimosa (Leguminosae: Mimosoideae): a preliminary analysis of southern South American species based on chloroplast DNA sequence. Annals Missouri Botanical Garden 95: 567-579.

Britton, N.L. \& Rose, J.N. 1928. Leptoglottis, Mimosa, Pteromimosa, Neomimosa, Lomoplis, Mimosopsis, Acanthopteron, Haitimimosa. North American Flora 23: 162.

Brummit, R.K. \& Powell, C.E. 1992. Authors of plant names. Royal Botanic Gardens, Kew. Pp. 1-732 p.

Burkart, A. 1948. Las especies de Mimosa de la flora Argentina. Darwiniana 8: 9-231.

Camargo-Ricalde, S.L. 2000. Description, distribución, anatomía, composición química y usos de Mimosa tenuiflora (Fabaceae-Mimosoideae) em México. Revista de Biología tropical 48:1-23.

De Candolle, A.P. 1825. Leguminosae In: De Candolle, A.P. Prodromus Systematis Naturalis Regni Vegetabilis. Vol. 2. Treuttell \& Würtz, Paris. Pp. 93-423.

Fortunato, R.H. \& Palese, R. 1999. Una especie nueva del género Mimosa L. (Fabaceae-Mimoseae) para 
el Chaco boliviano: M. craspedisetosa Fortunato \& Palese. Contribución al estudio de la flora y vegetación del Chaco. XIII. Candollea 54: 83-87.

Grether, R. 2000. Nomenclatural changes in the genus Mimosa (Fabaceae, Mimosoideae) in southern Mexico and Central America. Novon 10: 29-37.

Hassler, E. 1919. Ex herbário Hassleriano: novitates paraguarienses. XXIII. Leguminosae, Mimoseae. Repertorium Specierum Novarum Regni Vegetabilis 16: 151-156.

Heringer, E.P. \& Paula, J.E. 1979. Um novo par vicariante: Mimosa schomburgkii Benth. (Floresta amazônica) e Mimos artemisiana Heringer \& Paula sp. nov. (Floresta atlântica). Anais da Sociedade Botânica do Brasil, XXX Congresso Nacional e Botânica, Campo Grande. Pp. 75-82.

Jobson, R.W. \& Luckow, M. 2007. Phylogenetic study of the genus Piptadenia (Mimosoideae: Leguminosae) using plastid $t r n \mathrm{~L}-\mathrm{F}$ and $t r n \mathrm{~K} / m a t \mathrm{~K}$ sequence data. Systematic Botany 32: 569-575.

Kuntze, C.E.O. 1891. Revisio Generum Plantarum. Arthur Felix, Leipzig. 1: 198.

Lewis, G.P. 1987. Legumes of Bahia. Royal Botanic Gardens, Kew. Pp. 1-369.

Luckow, M.; White, P.J. \& Bruneau, A. 2000. Relationships among the basal genera of mimosoids legumes. In: Herendeen, P.S. \& Bruneau, A. (eds.). Advances in Legume Systematics. Royal Botanic Gardens, Kew, 9: 15-180.

Luckow, M. 2005. Mimoseae. In: G.P. Lewis; B. Schrire; B.A. Mackinder \& M. Lock (eds.). Legumes of the World. Royal Botanical Gardens, Kew. Pp. 163-185.

Malme, G.O.A. 1900. Adjumenta ad floram phanerogamicam brasiliae terrarumque adjacentium cognosdcendam. Bihang till Kongliga Svenska Vetenskaps-Akademiens Handlingar 25: 36-41.

Martius, C.F.P. von. 1837. Acacia. In: Flora Brasiliensis. Flora 20 (2, Beibl.): 107.

McNeill, J.; Barrie, F.R.; Buck, W.R; Demoulin, V.; Greuter, W.; Hawksworth, D.L.; Herendeen, P.S.; Knapp, S.; Marhold, K.; Prado, J.; Prud'homme van Reine, W.F.; Smith, G.E.; Wiersema, J.H. \& Turland, N.J. (eds). 2012. International Code of Nomenclature for algae, fungi, and plants (Melbourne Code), Adopted by the Eighteenth International Botanical Congress Melbourne, Australia, July 2011 (electronic ed.). International Association for Plant Taxonomy, Bratislava. 140p.

Mori, S.A.; Silva, L.A.M.; Lisboa, G. \& Coradin, L. 1989. Manual de Manejo de Herbário Fanerogâmico. $2^{\mathrm{a}}$ ed. Centro de Pesquisa do Cacau, Ilhéus. 104p.
Queiroz, L.P. 2009. Leguminosas da Caatinga. Universidade de Feira de Santana, Feira de Santana. Pp. 1-467.

Radford, A. E.; Dickison, W.C; Massey, R. \& Bell, C.R. 1974. Vascular plant systematics. Harper \& Row Publishers, Inc., New York. Pp. 1-891.

Rizzini, C.T. 1980. Notulas taxonômicas sobre Leguminosas brasileiras. Rodriguésia 55: 15-30.

Santos-Silva, J. \& Sales, M.F. 2008. O gênero Mimosa L. (Leguminosae-Mimosoideae) na microrregião do Vale do Ipanema, Pernambuco. Rodriguésia 59: 435-448.

Santos-Silva, J. \& Sales, M.F. 2010. Diversidade e potencial econômico de Mimosa L. (LeguminosaeMimosoideae) em Pernambuco, Brasil. In: Albuquerque, U.P.; Moura, A.N. \& Araújo, E.L. (eds.). Biodiversidade potencial econômico e processos ecofisiológicos em ecossistemas nordestinos. Vol. 2. Canal6, Bauru/NUPEEA, Recife. Pp. 283-313

Santos-Silva, J.; Simon, M.F. \& Tozzi, A.M.G.A. 2013. A new species of "jurema" (Mimosa ser. Leiocarpae Benth.) from Bahia, Brazil. Systematic Botany 38: 127-131.

Santos-Silva. 2013. Filogenia, estudos micromorfológicos e revisão taxonômica de Mimosa ser. Leiocarpae Benth. (Leguminosae-Mimosoideae). Tese de Doutorado. Universidade Estadual de Campinas, Campinas. 281p.

Silva, R.R. \& Tozzi, A.M.G.A. 2011. Uma nova espécie de Mimosa L. (Leguminosae, Mimosoideae) do Centro-Oeste do Brasil. Hoehnea 38: 143-146.

Simon, M.F.; Grether, R.; Queiroz, L.P.; Särkinen, T.E., Dutra, V.F. \& Hughes, C.E. 2011. The evolutionary history of Mimosa (Leguminosae): toward a phylogeny of the sensitive plants. American Journal of Botany 98: 1201-1221.

Sulaiman, S.F.; Culham, A. \& Harborne, J.B. 2003. Molecular phylogeny of Fabaceae based on $r b c \mathrm{~L}$ sequence data: with special emphasis on the tribe Mimoseae (Mimosoideae). Asia Pacific Journal of Molecular Biology and Biotechnology 11: 9-35.

Taubert, P.H.W. 1892. Leguminosae novae v. minus cognitae austro-americanae. Flora 75: 72.

Thiers, B. [continuously updated]. Index Herbariorum: A global directory of public herbaria and associated staff. New York Botanical Garden's Virtual Herbarium. Disponível em $<$ http://sweetgum.nybg. org/ih/>. Acesso em 07 dezembro 2014.

Willdenow, C.L. 1806. Species plantarum. G.C. Nauk, Berlim. 4: 1088. 
Lista de coletores

Agra, M.F. 1131 (19), 1750 (4.1); Aguiar, C.M.L. 3 (4.1); Aguiar, R.M. 1 (11); Alcântra, M.B. 43 (5); Alcoforado Filho, F.G. 301 (1.1), 330 (1.1), 348 (27) 368 (1.1); Alemão, Fr. 529 (24); Alencar, M.E. 49 (24), 50 (24), 234 (24), 258 (1.1), 583 (27), 585 (1.1), 679 (1.1); Allen, D.O. 3326 (25); Almeida, E.F. 279 (27); Almeida, K. 159 (21); Alvarenga, D. 89 (6); Alves, F.M. 40 (12); Alves, L.J. 125 (11); Amorim A.M. 2741 (11), 3891 (19); Anderson, W.R. 6802 (20), 6984 (9), 8326 (20), 9668 (3), 11523 (4.1), 36494 (9), 36554 (9), 36791 (24), 36990 (19); Andrade, B.S. 9 (24); Andrade, M.J.G. 272 (24); Angélica, M. s.n. - IPA 47081 (19); Antunes, J. 98 (1.1); Araquistain, M. 3565 (4.2); Arateguieta, L. 5590 (24); Araújo, A.P. 28 (11); Araújo, F.S. 1544 (24), 1476 (1.1), 1567 (27); Arbo, M.M. 3546 (13), 7648 (4.1); Árbocz, G.F. 412 (21), 685 (22), 3689 (3); Arboleda, O. 654 (4.2); Archer, W.A. 133 (14); Arouck-Ferreira, J.D.C. 245 (19); Assis M.C. s.n. - SPF 64657 (11), 11538 (11); Assis, A.M. 1861 (3); Atkinson, R. 2383 (17); Axelrod, F. 9676 (4.1); Bandeira, F.P. 88 (24), 230 (19); Barbeiro, S.M.C. 2768 (27); Barneby, R. s.n. - US 2249200 (11); Barreto, V. 155 (24); Barros, A.A.M. 619 (21), 2604 (21); Barros, E.O. 143 (19); Barros, F. 893 (14); Barroso, G.M. 9 (27); Barros, L.M.R. 143 (19); Bartalini, J.R. s.n - RB 410636 (21), s.n. - RB 497285 (21); Basto, B.C. 43 (19), 311 (4.1), 539 (4.1); Batalha, M.A. 2012 (5), 2624 (5), 2299 (5), 3057 (2), 3315 (14), 3851 (5), 3589 (2); Bautista, H.P. 872 (27), 951 (11), 1500 (20), 3224 (17); Benjamin, M.T. 401 (4.1); Belém, R.P. 3765 (4.1); Bernardi 20407 (12); Bernandi, L. 20620 (10); Bezerra, M. 5 (24); Bezerra-Loiola, M.I. 218 (24); Bianchetti, L.B. 694 (27); F. Billiet 7948 (4.1), 7969 (4.1); Bockermann, W. 319 (24); Borba, E.L. 1993 (24); Borges, L.B. 18 (11); Brito, H.S. 291 (19), 327 (22), 314 (27), 345 (6), 760 (22), 6650 (22); Brochado, A.L. 147 (11); Broks, R.R. 458 (11); Bucci, F. 69 (UFG) (14); Calzada, J.I. 15144 (24); Canto, S.P. s.n. - CGMS 16112 (14); Cárdenas, L. 2547 (4.2), 2895 (4.2), 2897 (4.2), 2899 (4.2), 3010 (4.2); Cardoso, C.F.R. 34 (6); Cardoso, D. 79 (1.1), 90 (24), 862 (27), 1750 (27); Carneiros, D.S. 558 (19); Carneiro-Torres, D.S. 447 (24), 465 (4.1), 475 (24), 539 (24); Carauta, J.P.P. 1858 (27); Carvalho, A.M. s.n. - K 90627 (24), 2 (24), 1860 (4.1), 1919 (24), 2424 (11), 3111 (4.1), 3697 (11), 3788 (19), 3923 (19), 3957 (1.1), 4029 (20), 4031 (22); Carvalho, C.A.L. de 54 (4.1); Carvalho G.H. 515 (19); Carvalho, J.H. 474 (24), 487 (1.1); Carvalho, M.G. 83 (20); Carvalho, M.V.B. 40 (4.1); Carvalho, P.D. 138 (19); Carvalho, R.A. 12 (24); Carvalho-Sobrinho, J.G. 398 (1.1), 1897 (19), 2148 (19), 2170 (19); Cavalo, G.P. 383 (4.1); Castellanos, A. 533 (24), 579 (27), 612 (27), 22840 (24), 22938 (19), 22939 (24), 25800 (19), 25854 (19), 25946 (4.1); Castilho. A. 3032 (4.1); Castro, R.M. 1241 (4.1); Cavalcanti, F.S. s.n. - EAC 32532 (27); Cavalcanti, P.B. 352 (21); Cavalcanti, T.B. 754 (22), 1623 (20), 2806 (23), 3229 (22); Cedillo, R. 1390 (4.2); Chagas e Silva, F. 751 (3); Chaplin, G. 441 (24); Claussen, P. s.n. - K (4.1); Coelho, B.B.S. s.n. - RB 264781 (21); Coelho, D.M. 488 (24); Coelho, M.M. 4 (24), 11 (19); Conceição, A.A. 1111 (24), 1188 (24), 1522 (27), 1600 (19), 2717 (24), 2807 (20); Conceição, A.S. 638 (11), 1188 (24); Conceição, S.F. 1 (4.1), 56 (24), $71(24), 78$ (24), 283 (24), 656 (11); Constantino, R. 79 (12); Coradin, L. 1350 (4.1), 2580 (27), 2883 (27), 5737 (24), 5746 (1.1), 5750 (27), 5763 (1.1), 5773 (20), 5978 (19), 5947 (19), 6019 (4.1), 6307 (27), 6314 (1.1), 7748 (27), 8489 (20); Cordeiro, I. s.n. - SPF 22490) (11); Cordeiro, L.M. 167 (24); Córdula, E. 179 (24), 265 (4.1), 282 (24); Correia, C. 195 (24), 197 (24), 250 (19); Costa, A.L. s.n. - ALCB 01325 (24); Costa, J. 426 (24); Costa, J.M. 84 (27); Croat, T.B. 54670 (4.1), 74742 (24), 63893 (24); Curran, C.H.M. 149 (24), 281 (24); Cutler, H.C. 8124 (2.1.); Daly, D.C. 1754 (1.2); Damascena, L. 3, 66, 68 (11); Daniel, T.F. 9832 (24); Davidse, G. 4224 (4.1), 11666 (2.1.), 12184 (27); Davis, P.H. 61142 (24); (24); Del'arco, M.R. s.n. - TEPB 982 (27), s.n. - TEPB 489 (27); Diego, N. 5394 (4.2); Dórea, M.C. 1 (4.1); Drouet, F. s.n. - US (24), s.n. - MO 1115423 (4.1), s.n. - US 1691015 (24), 2434 (24); Duarte, A.F. 7827 (20) Duarte, A.P. 8555 (11), 10320 (13); Duarte, L. 342 (24), 460-A (19); Dubs, B. 2037 (16); Ducke, A. s.n. - RB 35521 (21), s.n. - US 1040267 (24), 519 (21), 579 (21), 1222 (21), 1621 (24), 2237 (24); Edwards, J.B. 372 (24); Eiten, G. 5011 (4.1), 10508 (1.1), 10867 (27), 10830 (27), 4138 B (27), 4138b (24), 4184 (1.2), 4953 (24), 8359 (3), 9902 (16); Emperaire, L. s.n. - RB 351271 (27); Esteves, G.L. 509 (4.1), 2567 (4.1); Farias, E. de 1 (4.1); Faria, S.M.A. s.n. - NY 1045992; RB 344652; 138 (24), 1432 (10), 1428 (10), 1432 (10); Farias, R. 346 (3), 388 (22); Farias, R.R. 493 (1.1); Farias, S.M. de 1428 (12), 1447 (12), 1801 (19), 2471 (21), 1798 (24), 2235 (11); Felfili, J.M. 193 (20); Félix, L.P. s.n. - HST 5173, HUEFS 27625 (4.1), 7866 (27); Fennell, M. 375 (4.2); Fernandes, A. s.n - NY 419415 (6), s.n. - EAC 10725, NY 936049 (22); s.n. - EAC 21462, HUEFS 125345 (27); Ferraz, J. 26 (24), 55 (19); Ferreira, H.D. 2311 (14), 2520 (14), 2521 (5), 2527 (14); Ferreira, J.L. 26 (11); Ferreira, M.C. 586 (19), 1110 (11); Ferreira, M.L. 587 (19); Ferrucci, M.S.: 2580 (1.1); Figueiredo, L. 276 (19), 483 (19); Figueiredo, M.A. 126 (24), 200 (24), 567 (24), 617 (19), (TEPB) (24); Figueiredo, R. s.n. - SP 50029 (21); Filho, S.J. 158 (21); Fonseca, M.L. 513 (22), 552 (24), 1989 (14), 2888 (22); Fonseca,W.N. 392 (11), 385 (19); Fotius, G. 3332 (19), 3452 (27), 3477 (1.1), 3499 (24); França, F. 262 (22), 1629 (4.1), 1810 (24), 2161 (11), 2262 (1.1), 2277 (9), 2429 (11), 2840 (17), 3752 (11), 3756 (11), 4676 (11), 4687 (17), 5193 (11), 5318 (24), 5658 (17); Freire, F.M.T. s.n. - TEPB (24), s.n. - TEPB 3684 (27), s.n. - TEPB 1713 (27); Freire-Fierro, A. 1799 (27), 1835 (27), 1959 (27); Fróes, R.L. 20113 (11); Fromm, E. 1083 (24); Fuentes, A. 449 (8), 753 (8), 1000 (8), 2195 (7); Funch, L.S. 165 (2.1.); Furlan, A. 719 (4.1); Gadelha, F. s.n. - HST 16483, HUEFS 151304 (1.1); Gallindo, F. s.n. - IPA 60347, HUEFS 65168 (19); García, A.R. 1460 (24); García-Barriga H. 18938 (25); Gentry, A. 7501 (21), 49977 (19), 74424 (2.2.); Gerrit, D. 20008 (4.1); Giulietti, A.M. 1773 (19), 1803 (19), 1803 (1.1), 1862 (19), 1862 (1.1), 1893 (11), 1982 (11), 1985 (11), 2024 (20), 2075 (20), 2273 (11); Glaziou, A. s.n. - K (4.1), 973 (1.1), 9775 (27); 21040 (11); Gomes, A.P.S. 30 (4.1), 50 (1.1), 44 (19), 153 (24), 304 (11); Gomes, M.L. 36 (19); Gomes, V. 2745 (21); Gonçalves, J.M. 17 (17); Grear, J.W. 14939 (3); Groppo Júnior, M. 738 (11), 744 (20), 726 (24); Gross, E. 29 (1.1); Guala, G.F. 1376 (2); Guedes, M.L. 2725 (11), 3079 (27), 5330 (11), 6995 (27), 7175 (19), 7315 (19), 7862 (24), 7909 (19), 7934 (11), 15815 (11), 15974 (24), 16001 (24); Guevara, R.R. 188 (24); Gust, A. s.n. - RB 3336 (13); Hage, J.L. 2293 (11); Hahn, W. 1335 (12); Harley, R.M 1560 (1.1), 15607 (1.1), 16265 (4.1), 12066 (1.1), 15369 (11), 16304 (19), 16451 (19), 16466 (19), 16714 (11), 18967 (24), 18971 (24), 19160 (27), 19143 (1.1), 19469 (4.1), 19862 (27), 20945 (11), 21116 (11), 21402 (24), $21416(24), 21519$ (24), 21795 (22), 22812 (17), 22996 (17), 22997 (17), 23006 (4.1), 25005 (11), 53724 (20), 54134 (19), 54182 (19), 54344 (27), 54368 (1.1), 55961 (20), 56111 (24); Hastschbach, G. 21767 (14), 23654 (14), 31678 (11), 34109 (16), 39486 (6), 39486 (11), 39516 (24), 41270 (4.1), 42092 (1.1), 42029 (22), 42332 (27), 42295 (22), 46314 (21), 46347 (19), 47406 (11), 47356 (19), 47357 (19), 50033 (11), 50041 (24), 50519 (22), 53080 (4.1), 53356 (24), 54003 (13), 54050 (9), 54212 (11), 54947 (4.1); 55117 (11), 55121 (4.1), 60460 (13), 60683 (3), 60807 (7), 62158 (20), 61971 (1.1), 62124 (15), 62155 (3), 62716 (16), 62816 (3), 62816 (16), 64623 (4.1), 64625 (4.1), 65034 (4.1), 65742 (4.1), 65799 
(19), 66896 (14), $67747(1.1), 69557$ (11), 70761 (9), 70870 (9), 72860 (1.1), 73224 (15), 73349 (12), 73671 (11), 73900 (15), 74403 (1.1), 76084 (15), 77058 (1.1), 77300 (1.1), 78030 (20); Haught, O. s.n. - MO 1630013 (4.2); Hellin, J.J. 15 (21); Heringer, E.P. s.n. - RB 171745 (20), s.n. - RB 127560 (19), 82 (27), 106 (21), 340 (19), 6265 (19), 6871 (1.1), 6958 (21), 9810, 12037 (20), 12209 (19), 12781 (21), 12783, 13935 (21), 14108 (20), 14454 (20), 14783 (21), 14845 (21), 15506 (21), 15508 (19), 15731 (21), 15897 (21), 16740 (16), 18476 (20), 18165 (21), 18275 (19), 18299 (21), 18669 (21); Hoehne, F.C. 5731 (21); Hoenicka B., H. 30 (4.1); House, P.R. 1969 (21); Hughes, C.E. 106 (24), 522 (24); Irwin, H.S. 6337 (16), 6350 (3), 9764 (11), 13437 (11), 14392 (22), 14548 (3), 14811 (22), 14939 (3), 15205 (20), 15436 (20), 16739 (3), 16740 (16), 16880 (3), 17541 (16), 17606 (16), 22990 (11), 23683 (4.1), 30775 (11), 31422 (9), 31469 (20), 31582 (1.1); Jahn, A. 1193 (11); Jardim J.G. 36 (11), 1778 (21), 906 (22); Jobert-Schwacke 1003 (27); John, A. 1199 (24); Johnson, C.D. 893 (24), $1262-79$ (4.2), 3780-85 (4.1); Johnson, C.O. 767 (24); Jordy Filho, S. 24 (19), 189 (27); Jost, T. 541 (27); Júnior, D. 2128 (12); King, R.M. 1153 (4.2); Killip, E.P. 37265 (21); Kirkhride Júnior, J.H. s.n. - RB 253038 (20), 5234 (20); Krieger, L. 15737 (21); Krukoff, B.A. 2057 (16); Kubl, J.J. s.n. - RB 102190 (21); Kuhlmann, J.G. s.n. - RB 83428, UEC 7002 (21); s.n. - RB 102661 (21), s.n. - US 21244900 (21); Lacerda, A.V. 20 (24), 65 (24), 72 (19), 172 (19), 180 (19), 232 (19), 436 (19), 451 (19), 526 (24), 528 (24); Ladd O, M. 2005 (4.2); Lanna 706 (11); Laurênio, A. 212 (4.1); Leitão Filho, H.F. 2087 (14), 2113 (14), 12970 (14); Leite, K.R.B. 18 (27), 371 (24), 374 (24), 388 (27), 397 (27); Lemos M.J.S. 142 (19); Lemos, J.R. 47 (24), 210 (24), 327 (27), 377 (4.1); Lescano, L.E.A.M. 115, 217 (12); Lewis G.P. s.n. - K (19), s.n. - K 90589, SPF 36319 (19), 977 (11), 978 (19), 1094 (1.1), 1101 (19), 1145 (1.1), 1871 (24), 1886 (18); 7491 (24); Lima, D.A. 25272 (19), 52-1139 (27), $52-1140$ (4.1); Lima, H.C. 3882 (11), 3891 (17), 3942 (27), 6607 (21); Lima, I.B. 20 (24), 34 (19), 65 (24), 66 (19), 67 (19), 161 (19); Lima, L.C.L. 174 (4.1), 175 (20), 180 (19), 184 (20), 186 (20), 187 (20), 189 (20); Lima-Verde, L.W. 638 (1.1); Liogier, A.H. s.n. - MO 4081627 (4.1); Lisbôa, M.A. s.n. - US (27); Little Júnior, E.L. 25056, 25443 (21); Loureiro, R.L. 178 (10); Loiola, M.I. 699 (24); Lott, E.J. 3806 (4.2); Lucena, M.F.A. 72 (4.1); Lughadha, E.N. 6157 (11); Lyra-Lemos, R.P. 6846 (24), 6998 (24); Macedo, A. 5293 (14); Machado, R.F. 50 (24), 186 (19), 213 (19); Macdeuga, T. 11 (2.2.); Macqueen, D.J. 45 (24); Macvaugh, R. 22514 (4.2), 25337 (4.2); Magalhães, G.M. 14902 (21); Magalhães, L.M.S. 424 (21); Maguire, B. s.n. - NY 56941, US 3024107 (14); 56941 (14), 56321 (14); Mamede, M.C.H. s.n. - SPF 30112 (11); Mariano, K.R.S. 9 (24), 25 (21), 62 (24); Martins, F.R. 16250 (13); Martins, P. s.n. - EAC 8076, NY 957736 (27); Martins, R.C. 408 (6); Mattos, J. s.n. - SP 115784 (21), 9790 (24); Mattos, L.A. 251 (4.1), 276 (11); Mayworm, M.A. 24 (4.1), 77 (4.1); Meireles, J.E. 736 (20); Meléndez, E. 178 (24); Mello-Silva, R. 2336 (13), 690 (11); Melo, A.C. 22 (24); Melo, E. 1534 (2.1.), 1596 (2.1.), 2482 (19), 3881 (4.1), 6341 (19), 6698 (4.1), 1088 (24), 6489 (24), 6733 (4.1), 7265 (24), 8300 (22), 8303 (22), 565958 (24); Melo, P.A. 134 (24); Melo, Y. 214 (19); Menandro, M.S. 81 (11); Mendes, I. s.n. - HST 16152, HUEFS 148584 (27), s.n. HST 16177, HUEFS 148589 (27); Mendes, M.S. 422 (11); Mendonça, R.C. 3169 (6), 3436 (27), 3663 (14), 3720 (6); 6052 (27); Menezes, N.L. s.n. - HUEFS 31931, SPF 42920 (11); s.n - UEC 45874 (11); Mexia, Y. 5624 (4.1); Mile, C.D. 2135 (4.2); Miranda, A.M. 167 (11), 5480 (24), 5567 (24), 5570 (24), 5603 (24), 5738 (19), 5913 (1.1), 5981 (22); Miranda, C.A. 325 (22); Miranda, E.B. 343 (1.1); Mojteiro, C.H. 93 (5); Monro, A. 2143 (24); Monteiro, M.T. 23184 (19); Monteiro, R.F. 240 (11), 10173 (24); Monteiro, V.M. 38 (24); Moraes, A.O. 130 (24); Moraes, M.V. 209 (11); Mori, S.A. s.n. - CEPEC 12289, US 2857031 (11), s.n. - MO 3876326 (4.1); 1110 (24), 13273 (4.1), 13387 (11), 13442 (19), 14225 (19); Moura, I.O. 372 (27); Nascimento, A. 243 (1.1); Nascimento G.S.G. 9 (24); Nascimento, J.G. 66 (19), 92 (1.1); Nascimento, M.S.B. 201 (27); Nascimento, O.C. 1048 (1.2); Nee, M. 37871 (8); Nelson, E.W. 2629 (2.2.); Nitta, A. 17277 (21); 3550 (19); Noblick, L.R. s.n. - HUEFS 1221 (24); 3480 (11), 3550 (19), 4279 (4.1), 4320 (4.1); Noguehi, D.K. 53 (12), 127, 221 (12); Nogueira, A. 137 (11); Nogueira, P.E. s.n. - IBGE 293 (20); Nunes, E. s.n. - NY 932282, EAC 7728 (16), s.n. - MO 3323636 (4.1); Nunes, G.P. 51 (12), 195 (12); Nunes, M.S. 34 (24); Nunes, T.S. 269 (24), 276 (11), 290 (11), 305 (24), 398 (24), 430 (27), 431 (24), 468 (27), 472 (27), 479 (24), 500 (24), 516 (27), 541 (27), 572 (4.1), 626 (19), 678(19), 904 (19), 971 (27), 1052 (1.1), 1235 (4.1), 1273 (19); Núñez, J.C.S. 1593 (4.2), 2061 (4.2), 8864 (24), 9143 (4.2); Oliveira Filho, L.C. 55 (22); Oliveira, A. s.n. - CGMS 581 (14), s.n. - CGMS 10639 (14); Oliveira, E.L.P.G. 217 (19), 404 (4.1); Oliveira, F.C.A. 333 (20), 554 (16); Oliveira, F.C.S. 17 (1.1), 18 (27), 107 (27); Oliveira, J.O.S. 6 (1.1); Oliveira, L.B. 7 (20); Oliveira, R.C. 1151 (22); Oliveira, R.P. 269 (24); Oliveira, U.R. 34 (1.1); Ozment, A. 578 (4.2); Pabst, G. 8351 (11); Pacheco, L.M. . 7 (19), 11 (24); Paiva, F. 1022 (27); Paiva, M.A.G. 37 (24); Paixão, L.J. 1560 (24); Paula, J.E. 1484 (19); Paula-Souza, J. 5079 (11), 5172 (19), 5204 (18), 5532 (19), 9215 (22); Paula-Zárate, E.L. 224 (24); Paulo, S. 39 (4.1); Pedra, M.G. 2770 (14); Pedralli, G. s.n. - RB 379649 (21); Pennington, T.D. 13413 (21); Pereira Neto, M. 424 (6) Pereira, B.A.S. 29 (20), 1633 (6), 3017 (9); Pereira, E. 7548 (21), 8421 (11), 8983 (20), 10036 (24); Pereira, P. 2585 (24), 2588 (24); Pereira, R. 1129 (4.1), 2588 (24); Pereira, U.S. 36 (27); Pereira Silva, G. 2434 (19), 3105 (11), 3162 (22), 4565 (9), 9093 (20), 9128 (11), 11503 (9), 11532 (9); Pérez, B. 322 (12); Pesqueira, U.S. 57 (27), 62 (24); Philcox, D. 3715 (3), 4475 (16); Pickel, B. s.n. - IPA 3880 (4.1), 25 (21), 1449 (4.1), 1085 (21); Piedade, K.L.H. s.n. - RB 378921 (27); Pinheiro, K. 146 (4.1); Pinheiro, M.C. 176 (24); Pinto, G.C.P. 99/83 (2.1.); Pirani, J.R. s.n. - SPF 67601) (11), s.n. - SPF 67987) (11), 2322 (4.1), 12536 (11), 12735 (11); Pires, J.M. 1482 (21), 8184 (21), 51891 (21), 56941 (15), 9478 (20), 17225 (15); Pittier, H. 11307 (24), 11795 (24), 12615 (4.2), 13095 (4.1), 13104 (11); Pizziolo, R.B. 173 (21); Ponce, M. s.n. - K (11); Pontual, I. 754 (19); Pott, A. 10578 (15), 11428 (15), 13033 (3), 14130 (15), 14130 (16), 14142 (13), 14142 (11); Prance, G.T. 4105 (21), 4161 (21), 18925 (14); Proença, C. 1556 (14), 1740 (20); Pursell, R.A. 8308 (21) Queiroz, L.P. de 418 (1.1), 487 (1.1), 1234 (11), 1702 (24), 1728 (4.1), 1737 (4.1), 2124 (6), 2628 (11), 3096 (4.1), 3123 (4.1), 3322 (24), 3247 (4.1), 3266 (24), 3328 (11), 3346 (11), 3377 (11), 3389 (19), 3396 (19), 3424 (19), 3478 (4.1), 3533 (24), 3575 (11), 3642 (24), 3694 (18), 3745 (19), 3830 (4.1), 3858 (4.1), 3905 (24), 3923 (1.1), 3935 (27), 4185 (1.1), 4188 (24), 4289 (17), 4550 (20), 4586 (19), 4663 (4.1), 4870 (1.1.), 4913 (11), 5706 (19), 5904 (19), 6223 (1.1), 6248 (27), 6561 (1.1), 6580 (1.1), 6597 (1.1), 6600 (27), 6624 (24), 7256 (19), 7322 (4.1), 7327 (19), 7387 (27), 7400 (27), 7635 (11), 7815 (20), 7857 (1.1), 7841 (24), 7874 (24), 7885 (27), 7922 (19), 7950 (24), 7926 (24), 8005 (27), 8008 (27), 8028 (27), 8084 (27), 9046 (19), 9097 (27), 9125 (1.1), 9138 (27), 9568 (24), 9591 (19), 10064 (1.1), 10128 (1.1), 10287 (20), 10584 (16), 10669 (4.1), 10933 (24), 10936 (27), 12651 (11), 13009 (24), 13965 (9), 13065 (24), 13117 (24), 14615 (1.1), 14625 (1.1), 14827 (11), 14630 (27), 14891 (19); Ramalho, F.B. 173 (27); Ramalho, R.S. 1390 (21), 2203 (21), 2920 (21), 3590 (21); Rapini, A. 1460 (11); Ratter, J.A. 297 (16), 4171 (16), 5086 (3), 8033 (22), 8300 (22); Record, S.J. 73 (21); Reeves, R.D. 458 (11); 
Reyna, M.L. 1429, 1434 (24); Ribas, O.S. 2420 (12), 7692 (11); Ribeiro, A.J. 38 (17); Ribeiro, B.G.S. 1335 (1.2); Ribeiro, R.D. 1091 (21); Ricco, L. 904 (4.2), 1058 (4.2); Rivello, N. s.n. - RB 308973 (21), s.n. - RB 316112 (21); Rizzo, J.A. 161 (22), 7612 (20), 7874 (9); Robert, A. 878 (12); Roberto, P.O. 367 (11); Rocha D. 5 (11), 19 (11), 20 (11), 222 (11), 323 (24); Rodal, M.J.N. 427 (11), 822 (19); Rodrigues, J. s.n. - HST 16138, HUEFS 148573 (1.1); Rodrigues, W. 4355 (21); Rombouts, J.E. 261 (IAC) (14); Romero, L.C. 114 (14); Romero-Castañeda, R. 10479 (4.2); Roque, N. 540 (27), 641 (11); Rosa, N.A. 1434 (21); Rothschild, B.M. 380 (4.2); Ruíz, T. 3660 (4.2); Sales, M.F. 210 (4.1), 279 (4.1); Sá e Silva, I.M.M. 361 (24); Saar, E. 8 (19), 13 (4.1), 5103 (19); Salgado, O.A. 44 (27), 349 (11); Salino, A. 3985 (6); Salviani, E.R. 49 (12); Sampaio, A.B. 551 (23); Sandwi s.n. - US 1661912 (16); Santana, W. s.n. (ALCB 00293, HUEFS 02351) (24); Santin, D.A. s.n (UEC) (12); Santos R.R. s.n. - RB 165727 (20); Santos, A.K.A. 371 (11); Santos, H.G.P. 424 (9); Santos, M. 145 (21); Santos, R.M. 1384 (27); Santos, S. 115 (24); Santos, V.J. 546 (19); Saravia, C. 524 (24), 2204 (24), 2920 (24); Sartori, A.L.B. 599 (3); Saunders, J. 1071 (21); Schinini, A. 29344 (12); Schomburgk 313 (21); Secco, R.S. 128 (1.2); Semir, J. 9680 (2.1.), Senna, L.R. 2 (24); Sertão, S. 27943 (12); Sevilha, A.C. 1811 (6); Shepherd, G.J. 7520 (3); Silva, J.S. 193 (19), 827 (27), 837 (24), 838 (19), 839 (24), 852 (12), 869 (14), 900 (15), 901 (15), 912 (10), 913 (11), 970 (5), 973 (5), 976 (2), 977 (2), 978 (4), 988 (20), 1101 (5), 1102 (20), 1104 (9), 1105 (3), 1118 (23), 1141 (23), 1142 (22), 1143 (22), 1145 (23), 1154 (23), 1155 (22), 1156 (22); 1170 (20), 1174 (3), 1175 (13), 1177 (3), 1178 (20), 1186 (6), 1187 (6); 1188 (20); 1096 (20); 1098 (9); Silva, A.S.L.1822 (1.2); Silva, S.B. da 286 (27); Silva, G.C. 3 (24), 4 (19); Silva, M. A. 2056 ( 7 ), 2924 (20); Silva, M.F.D. 1174 (1.2); Silva, M.L. 154 (4.1); Silva, M.M. da 364 (4.1), 455 (24), 460 (27), 490 (27); Silva, R.A. 1853 (1.1); Silva, R.R. 390,871 (9); Silva, S.B. 286 (27), 340 (20), 367 (1.1); Silva, S.S. s.n. - IBGE 2810590, US 3186172 (1.1); Silva, T.R.S. 105 (11), 96 (11); Silva, V.D. 69 (19); Simon, M.F. 165 (27), 211 (27), 281 (20), 245 (11), 324 (6), 410 (22), 481 (19), 543 (24), 690 (11), 698 (24), 701 (19), 706 (27), 707 (1.1), 714 (11), 754 (20); Siqueira-Filho, J.A. 1641 (24), 1729 (27); Smith, N.P. 47 (24); Smith, F.D. 142 (24); Soares, C.B.V. s.n. - R 172757, RB 287964 (21); Soares, L.H. 887 (22); Sobrinho, J.S. 30 (4.1), 42 (27), 244 (11); Solórzano, A. 87 (27); Soria, N. 4630 (12); Soto, D. 1119 (8); Sousa, E.R. 299 (1.1); Souza, G.M. 110 (4.1); Sousa, M. 8024 (4.2), 10697 (4.2), 11921 (24), 12954 (4.2); Souza, H.M. s.n. - IAC 20070 (14); Souza, S. 6846 (24); Souza, V.C. 24375 (27), 5264 (19); Souza-Silva, R.F. 228 (11); Sperling, C.R. 5594 (1.2); Steinmann, V.W. 3227 (4.2); Steyermark, J.A. s.n. - US 2742649 (24), s.n. US 2742651 (24); Stevans, W.D. 26513 (4.2), 7781 (21), 7934 (21); Sucre, D. 9476 (27); Swaller, J.W. s.n. - US 1933188 (14); Syll 36 (3); Tamashiro, J.Y. 17899 (14); Tamayo, F.T. 4156 (21); Tavares, S. 675 (19), 853 (4.1); Teixeira, A.F.R. 06 (1.1); Teixeira, M.C.B. s.n. - RB 363855 (20); Tejera, E. 44 (14); Tenorio, P. 3433 (24); Thomas, W.W. 9618 (19), 9633 (19), 12934 (11); Tiritan, O. 86 (14); Tiujillo, B. 5970 (4.1); Torres C., M.L. 80 (4.2); Torres, R. 68 (24), 5229 (4.2), 9089 (24), 9234 (24); Tourinho, R. 43 (27); Trinta, Z. A. 703 (21); Tschá, M. 183 (4.1), 397 (24); Tucker, J.M. 423 (24); UMR 292 (3); Valente, G.E. 841 (21), 841 (27); Vasconcelos, M.B. 13550 (3); Vasconcelos, S.F. 1544 (24); Vasconcelos-Neto, J.R.T. 2 (4.1); Vassal, L.T. 83 (21); Vianna, S. 4049 (4.1); Villacorta, R. 2289 (24); Villarouco, F.M.O. 130 (4.1); Vital, J. 954 (19); Wenamu, R. 5621 (21); Wiggins, L.L. 48 (4.2); Willians, L.O. 11915 (24); Wilson, G. 3260 (20); Windish, P.G. 7236 (3); Wood, P.J. s. n. (FHO, K) (24); Woodgyer, E. 2490 (11), 2491 (1.1); Zappi, D.C. 722 (11); Zardini E.M. s.n. - MO 53959 (10); Zehntner 740 (19). 